NBER WORKING PAPER SERIES

\title{
ARE BIG CITIES BAD PLACES TO LIVE? ESTIMATING QUALITY OF LIFE ACROSS METROPOLITAN AREAS
}

\author{
David Albouy \\ Working Paper 14472 \\ http://www.nber.org/papers/w14472 \\ NATIONAL BUREAU OF ECONOMIC RESEARCH \\ 1050 Massachusetts Avenue \\ Cambridge, MA 02138 \\ November 2008
}

I would like to thank Soren Anderson, Patricia Beeson, Jeff Biddle, Dan Black, Glenn Blomquist, JS Butler, David Card, Paul Courant, Lucas Davis, Morris Davis, Gilles Duranton, Randall Eberts, Rob Gillezeau, Joseph Gyourko, Jim Hines, John Hoehn, Juanna Joensen, Matthew Kahn, Ryan Kellogg, Pat Kline, Jed Kolko, François Ortalo-Magné, Enrico Moretti, John Quigley, Jordan Rappaport, Stuart Rosenthal, Albert Saiz, David Savageau, Noah Smith, Gary Solon, Lowell Taylor, Casey Warman, Hendrik Wolff and the participants of seminars at Carnegie Mellon University, Columbia University, the Federal Reserve Bank of Chicago, Michigan State University, University of Kentucky, University of Michigan, the Stockholm School of Economics, University of Washington, University of Western Ontario, and Yale University and at the AREUEA Annual Meetings, Econometric Society North American Summer Meetings, NBER Public Economics Meetings, North American Regional Science Council Annual Meetings, and Society of Labor Economics Annual Meetings for their help, discussions, and advice. Olivier Deschenes and Wolfram Schlenker generously provided detailed weather data. Kevin A. Crosby, Walter Graf, and Bert Lue provided excellent research assistance. The National Science Foundation (SES-0922340) and the Center for Local, State, and Urban Policy (CLOSUP) provided generous financial assistance. Any mistakes are my own. Please e-mail any questions or comments to albouy@umich.edu. The views expressed herein are those of the author(s) and do not necessarily reflect the views of the National Bureau of Economic Research.

NBER working papers are circulated for discussion and comment purposes. They have not been peerreviewed or been subject to the review by the NBER Board of Directors that accompanies official NBER publications.

(C) 2008 by David Albouy. All rights reserved. Short sections of text, not to exceed two paragraphs, may be quoted without explicit permission provided that full credit, including $@$ notice, is given to the source. 
Are Big Cities Bad Places to Live? Estimating Quality of Life across Metropolitan Areas

David Albouy

NBER Working Paper No. 14472

November 2008, Revised February 2011

JEL No. H4,J3,Q51,Q54,R1

\begin{abstract}
$\underline{\text { ABSTRACT }}$
The standard revealed-preference estimate of a city's quality of life is proportional to that city's cost-of-living relative to its wage-level. Adjusting estimates to account for federal taxes, non-housing costs, and non-labor income produces more plausible quality-of-life estimates than in the previous literature. Unlike previous estimates, adjusted quality-of-life measures successfully predict how housing costs rise with wage levels, are positively correlated with popular "livability" rankings and stated preferences, and do not decrease with city size. Mild seasons, sunshine, hills, and coastal proximity account for most inter-metropolitan quality-of-life differences. Amendments to quality-of-life measures for labor-market disequilibrium and household heterogeneity provide additional insights.
\end{abstract}

\author{
David Albouy \\ Department of Economics \\ University of Michigan \\ 611 Tappan Street \\ 351C Lorch Hall \\ Ann Arbor, MI 48109-1220 \\ and NBER \\ albouy@umich.edu
}




\section{Introduction}

The urban wage premium that cities offer is seen by economists as evidence not only of high urban productivity, but also as compensation for urban disamenities, such as crime, congestion, and pollution (Hoch 1972). This view feeds the stereotype that urban life is an unfortunate by-product of civilization, and leads Nordhaus and Tobin (1972) to discount economic growth measures for increasing urbanization when they attempt to measure changes in economic welfare over time. This view is also used to endorse policies to depopulate cities and subsidize rural areas for greater "population balance," as in the National Science Foundation report by Elgin et al. (1974). Yet, interest in urban quality of life persists, as seen recently in the theme of the 2010 World Expo in Shanghai, "Better City, Better Life," which according to the organizers represents "the common wish of humankind for a better living in future urban environments."

Rosen (1979) and Roback (1982) point out that high nominal wage levels may compensate for higher rents, as well as for disamenities. Overall, the value of a city's amenities, captured in its overall quality of life (QOL), is reflecte in how high its cost-of-living is relative to its wage level, i.e. the inverse of its real wage. Workers will live in a place where real wages are low if their lower consumption of market goods is offset by a higher consumption of non-market amenities. Using hedonic methods, these QOL measures are used to determine households' willingness-to-pay for amenities such as climate, safety, and clean air. ${ }^{1}$

Despite its solid foundations on revealed-preference theory, the QOL indices found in the economic literature (e.g. Blomquist, Berger, and Hoehn 1988; Gyourko and Tracy 1989) often seem counterintuitive or "misplaced"(Rappaport 2008). Ranking the QOL of states in 1990, Gabriel, Mattey, and Wascher (2003) put Wyoming, South Dakota, and Arkansas first second, and third, while putting seemingly more desirable Colorado, Hawaii and California in 34th, 35th, and 42nd. Ranking 185 metropolitan areas in the United States, Berger, Blomquist and Waldner (1987) rank Pueblo, CO, Macon, GA, and Reno, NV in the top three, while San Francisco, CA, is 105th; Seattle, WA, 144th; and New York, NY, 165th. These city rankings are correlated negatively with city

\footnotetext{
${ }^{1}$ Gyourko, Kahn, and Tracy (1999) and Lambiri, Biagi, and Royeula (2007) are excellent guides to this literature.
} 
size (Burnell and Galster 1992) and with QOL rankings found in popular guides, such as the Places Rated Almanac (Savageau 1999), where many large cities score favorably in overall "livability."2

I argue here that the Rosen-Roback model produces more sensible QOL and amenity-value estimates once three adjustments are made. First, cost-of-living measures should incorporate cost differences beyond housing costs. Second, proper accounting must account for how urban wage levels affect a typical household's buying power. Third, wage differences should net out federal taxes. Across metropolitan areas - equated here with "cities" - the adjusted model successfully predicts that a one-percent increase in wages is associated with a 1.5 percent increase in housing costs, holding amenities constant, unlike previous studies, which predict a 3 to 4 percent increase. ${ }^{3}$

Estimates from the adjusted model, based on 2000 data, imply that real incomes in large cities are lower, and QOL higher, than previously thought. The two nicest cities in the United States are Honolulu and Santa Barbara, while San Francisco, Boston, Chicago, Los Angeles and New York are all above the national average; the top f ve states are Hawaii, California, Vermont, Colorado, and Oregon. These adjusted QOL rankings are positively correlated with rankings in Places Rated and rankings based on stated preferences. Adjusted amenity-value estimates indicate that households have a substantial willingness-to-pay to live in areas with coasts, slopes, sunshine, warm winters, and mild summers: a parsimonious model using only these f ve variables explains over 70 percent of the variation in QOL across cities. Valuations of artificia amenities are more tenuous, revealing a substantial willingness-to-pay to live in areas with arts and culture, bars and restaurants, and cleaner air. They fail to show positive valuations for safety from crime, an amenity that is geographically concentrated within metropolitan areas. Unadjusted hedonic estimates often produce counterintuitive valuations, findin mild summers, coastal proximity, and arts and culture to

\footnotetext{
${ }^{2}$ These differences persist when measured at the county level in Blomquist, Berger and Hoehn (1988) where suburban Marin County is ranked 142nd (out of 253 counties), even lower than the City and County of San Francisco, ranked 105th. Burnell and Galster (1992) note that, in Places Rated, QOL peaks at a city size of 4 million. Oppositely, Clark, Kahn, and Ofek (1992) fin that QOL reaches a minimum at 4 million with a measures based on nominal, not real, wages, arguing this is correct in a monocentric city model with free mobility, where - paradoxically - cities are of fi ed size. Hoehn, Berger, and Blomquist (1987), allow city size to be endogenous in a system of monocentric cities, and re-establish the need to use real wages.

${ }^{3}$ The Appendix demonstrates that a log-linear specificatio of QOL fit the data better than a linear specification and that a QOL model based on a second-order log-linearization, which incorporates tax progressivity and income and expenditures change, does little to change the estimates.
} 
be undesirable. Overall, larger cities tend to be located in areas with greater natural amenities, but once these are controlled for, there is no relationship between city size and QOL, implying that on average big cities are no worse to live in than small ones. It even appears that QOL may be higher in denser cities.

The last section of the paper considers amendments of the model to handle household heterogeneity in skills and preferences, as well as moving and adaptation costs. This section sheds light on structural discrete-choice models of household location and migration across metropolitan areas used to produce amenity valuations (e.g. Timmins 2007, Bishop 2008, Sinha and Cropper 2009). Economic reasoning suggests that larger or growing areas are more desirable to inframarginal residents than is estimated by QOL measures based on wages and costs alone. Dynamic considerations of local adaptation suggest that population growth, rather than level, is more useful for amending QOL measures. Thus, faster growing cities and their amenities - sunshine, slopes, warm weather, and clean air - may be even more desirable than the initial estimates presented. The marginal value of coastal proximity, an amenity very fi ed in supply, appears to be increasingly different from the average value. Lastly, as a consequence of Zipf's and Gibrat's laws for cities which imply that population levels and growth rates are uniformly distributed across city sizes neither population-level or growth amendments suggest a preference bias towards either smaller or larger cities.

Heterogeneous tastes across different household types for cities and amenities have generally been addressed by examining wage differences (e.g. Roback 1988; Beeson 1991; Black, Kolesnikova, and Taylor 2009; and Lee 2010). When applied to heterogenous households, the adjusted model successfully predicts that less-educated households are paid higher premia in more expensive and lower-wage areas. Relative QOL valuations appear problematic as they ignore the influenc of labor demand factors on wages, which imply that higher concentrations of a household type signal stronger tastes in addition to lower wages. This amendment produces more plausible measures of relative QOL values and reveals that more educated households appear to have 
stronger tastes for culture, entertainment, and clean air, and care less about crime. ${ }^{4}$

\section{Basic Theory and Calibration}

Assume that worker-households, whose types are indexed by $g$, are fully mobile across cities, indexed by $j$. Preferences are modeled by the utility function $U_{g}\left(\mathbf{y}, Q_{g}^{j}\right)$, which is increasing and quasi-concave over a vector of market goods, $\mathbf{y}$, and quality of life, $Q_{g}^{j}$, modeled by a scalar specifi to city and type. Local prices of $\mathbf{y}$ are given by the vector $\mathbf{p}^{j} . Q_{g}^{j}$ cannot be purchased directly and depends on city amenities, $\mathbf{Z}^{j}$, according to the function $\mathbf{Q}^{j}=\widetilde{Q}\left(\mathbf{Z}^{j}\right)$. Households supply a single unit of labor in their city of residence and earn a wage, $w_{g}^{j}$, and also receive non-labor income, $I_{g}$, which does not depend on the city of residence. ${ }^{5}$ Out of gross income, $m_{g}^{j}=w_{g}^{j}+I_{g}$, households pay a federal tax, $\tau\left(w_{g}^{j}+I_{g}\right) .^{6}$

The after-tax net expenditure necessary to obtain utility $u_{g}$, given local prices, wages, and QOL is written as $E_{g}\left(\mathbf{p}^{j}, w_{g}^{j}, \tau, u_{g} ; Q_{g}^{j}\right) \equiv \min _{\mathbf{y}}\left\{\mathbf{p}^{j} \cdot \mathbf{y}-w_{g}^{j}-I_{g}+\tau\left(w_{g}^{j}+I_{g}\right): U_{g}\left(\mathbf{y}, Q_{g}^{j}\right) \geq u_{g}\right\}$ Since households are fully mobile, each type's utility, $u_{g}$, must be equalized across the cities it inhabits. Therefore, in an equilibrium, no household requires additional compensation to live in its city:

$$
E_{g}\left(\mathbf{p}^{j}, w_{g}^{j}, \tau, \bar{u}_{g} ; Q_{g}^{j}\right)=0
$$

where $\bar{u}_{g}$ is the obtained utility. Totally differentiating (1) around national averages of $\overline{\mathbf{p}}, \bar{w}_{g}$ and $\bar{Q}_{g}$ produces $\partial E_{g} / \partial \mathbf{p}^{j} \cdot \mathbf{d} \mathbf{p}^{j}+\partial E / \partial w \cdot d w_{g}^{j}+\partial E_{g} / \partial Q \cdot d Q_{g}^{j}=0$. Applying Shepard's Lemma and rearranging this formula, $\mathbf{y}_{g} \cdot \mathbf{d} \mathbf{p}^{j}-\left(1-\tau_{g}^{\prime}\right) \cdot d w_{g}^{j}=p_{Q g} \cdot d Q_{g}^{j}$ where $\tau_{g}^{\prime}$ is the marginal tax rate

\footnotetext{
${ }^{4}$ The methods here meant to complement quasi-experimental estimates of amenity values (e.g. Black 1999, Chay and Greenstone 2005), and structural migration models with household heterogeneity (e.g. Kennan and Walker 2003), which all require that that population stocks or $\mathrm{fl}$ ws be weighted correctly together with wages and housing costs.

${ }^{5}$ Roback (1980) models elastic labor supply, and find it has no first-orde effects on QOL estimates.

${ }^{6}$ Deductions for local public goods and housing are left out here, but are included in the application and discussed in full in Albouy (2009a), which also explains how federal expenditures are not correlated with federal taxes, and most federal public goods, mainly defense, benefi areas fairly equally. Therefore, differences in disposable income across areas should be measured after federal taxes. The local public sector does not need explicitly modeling: Local government goods may be treated as consumption goods, part traded and part non-traded, and differences in local government efficien y may be reflecte in $Q$ (Gyourko and Tracy 1989).
} 
and $p_{Q g} \equiv-\partial E_{g} / \partial Q$ is the marginal willingness-to-pay for QOL. Log-linearizing this formula, so that $\hat{w}_{g}^{j} \equiv d w_{g}^{j} / \bar{w}_{g}, \hat{p}_{i}^{j}=d p_{i}^{j} / \bar{p}_{i}$, for each good $i$, and normalizing $\hat{Q}_{g}^{j} \equiv-\left(\partial E_{g} / \partial Q\right) \cdot d Q_{g}^{j} / \bar{m}_{g}$,

$$
\hat{Q}_{g}^{j}=\mathbf{s}_{\mathbf{y g}} \cdot \widehat{\mathbf{p}}^{j}-\left(1-\tau_{g}^{\prime}\right) s_{w g} \hat{w}_{g}^{j}
$$

where $\mathbf{s}_{\mathbf{y g}}$ is a vector of expenditure shares, out of gross income, and $s_{w g} \equiv \bar{w}_{g} / \bar{m}_{g}$ is the share of gross income received from labor. In percentage terms, $\mathbf{s}_{\mathbf{y g}} \cdot \widehat{\mathbf{p}}^{j}$ represents how high the costof-living is in city $j$ relative to the national average, while $s_{w g} \hat{w}_{g}^{j}$ represents how high nominal income is, with the $\left(1-\tau_{g}^{\prime}\right)$ netting out federal taxes. Thus, (2) equates local QOL with how much cost-of-living exceeds nominal income levels, or how low after-tax real incomes are relative to the national average. $\hat{Q}^{j}$ is cardinal and represents the percent of total consumption households are willing to forego to live in city $j$ instead of an average city.

Household preferences are likely to differ significantl, but a useful measure of aggregate willingness-pay is obtained by weighting each household type according to their income share, $\mu_{g}$. Basing the parameters and differentials on income-weighted household averages, definin $\mathbf{s}_{\mathbf{y}}=\sum_{g} \mu_{g} \mathbf{S}_{\mathbf{y g}}$ and $\left(1-\tau^{\prime}\right) s_{w} \hat{w}^{j} \equiv \sum_{g} \mu_{g}\left(1-\tau_{g}^{\prime}\right) s_{w g} \hat{w}_{g}^{j}$, we may drop the subscript $g$ from (2) to obtain an aggregate QOL, $\hat{Q}^{j} \equiv \sum_{g} \mu_{g} s_{w g}$. While simple, this single index should largely capture the average willingness to pay of most households to live in certain cities, at least for the "marginal" households that are willing to move across cities, which in the long run, include most Americans. ${ }^{7}$ In the absence of strong sorting, the index aggregates the preferences of those with low income shares from labor, such as students and retirees, who care more about high prices, with those with high income shares from labor, like young workers, who care more about wages. The approximations also obviate the need to model production side of the economy - discussed in Appendix A.1 and more fully in Albouy (2009b) - especially when preferences are homogenous. Indices to accommodate household heterogeneity, moving costs, and labor-market disequilibrium are considered in Section 5.

\footnotetext{
7 Sorting of this kind is greatly reduced if retirees decide to locate close to their children, especially if families share income. Retirees and their working children who locate together act like a family "dynasty" as in Barro (1974).
} 


\subsection{Choosing the Correct Parameters}

Simplifying somewhat, most QOL estimates in the literature are based on a single measure of wages and a single measure of prices, namely housing costs, here termed $\hat{p}_{\text {hous }}^{j}{ }^{8}$ They have also ignored federal taxes, treated labor as the only source of income, and put the expenditure share on housing, $s_{\text {hous }}$, at around 25 percent, so that (2) is reduced to

$$
\hat{Q}_{\text {unadjusted }}^{j}=0.25 \hat{p}_{\text {hous }}^{j}-\hat{w}^{j}
$$

The improved measure used here, still relies on single indices of wages and costs, but with the formula

$$
\hat{Q}_{\text {adjusted }}^{j}=0.33 \hat{p}_{\text {hous }}^{j}-0.51 \hat{w}^{j} .
$$

This formula incorporates an effective federal tax rate on labor income of 32 percent (with some adjustments for tax benefit to owner-occupied housing), the fact that 75 percent of household income depends on local wages, and that, netting out tax-benefit to owner-occupied housing, the cost-of-living differences across cities are approximated by a third of housing-cost differences. This parametrization puts only 1.5 times more weight on low wages relative to housing costs, unlike previous studies which put 4 times more weight. ${ }^{9}$

\subsection{The Effective Expenditure Share on Housing Costs}

Separating goods into housing and non-housing, the cost-of-living differential may be recast as

$$
\mathbf{s}_{\mathbf{y}} \cdot \widehat{\mathbf{p}}^{j}=s_{\text {hous }} \hat{p}_{\text {hous }}^{j}+s_{\text {oth }} \hat{p}_{\text {oth }}^{j},
$$

\footnotetext{
8"Housing cost" refers to rent or an imputed rent based on housing prices for home-owners. I follow the standard practice of including utilities since contract rents often include them.

${ }^{9}$ More specificall the relative weight on wages relative to housing costs is 3.61 in Blomquist et al. (1988), 3.7 in Beeson and Eberts (1989), 4.82 in Gyourko and Tracy (1991), 3.72 in Gabriel et al. (2003), 4 in Davis and OrthaloMagne (2007), and 2.87 in Chen and Rosenthal (2008). The latter is closest to the study here. Equation (2) is based on a first-orde approximation of the mobility condition. As shown in Appendix A.3, a second-order approximation has only a minute impact on QOL estimates. Furthermore, Davis and Ortalo-Magne (2007) provide empirical evidence that $s_{\text {hous }}$ is fairly constant across time and metropolitan areas, justifying the use of a single number for $s_{y}$.
} 
where $s_{\text {oth }}$ and $\hat{p}_{\text {oth }}$ are the expenditure share and cost differential for non-housing goods. The Consumer Expenditure Survey (CEX) reports the share of gross income spent on shelter and utilities, $s_{\text {hous }}$, is 0.213 , and on other goods, $s_{\text {oth }}$, is 0.563 (Bureau of Labor Statistics 2002). The other 22.4 percent is saved or taxed.

While data on regional differences in housing costs are of good quality, data on regional differences in the cost of other goods are limited. Commonly used data on other goods come from the ACCRA Cost-of-Living Index, which measures price differences across expenditure categories. Problems with this data, discussed by Koo, Phillips, and Sigalla (2000), are that they cover a limited number of goods, are collected by volunteers, are meant for urban professionals, may exaggerate housing-cost differences, and most importantly, have limited geographic coverage. For this last reason, I use ACCRA data to infer how housing costs predict overall cost-of-living differences. A regression using 2004 data in natural logarithms reveals that housing costs predict other prices well, as seen through the high coefficien of determination: ${ }^{10}$

$$
\ln p_{\text {oth }}^{j}=3.57+0.263 \ln p_{\text {hous }}+e^{j} \quad R^{2}=0.66
$$

Substituting in the regression formula, $\hat{p}_{\text {oth }}^{j}=b \hat{p}_{\text {hous }}^{j}+e^{j}$, into equation (5)

$$
\mathbf{s}_{\mathbf{y}} \cdot \widehat{\mathbf{p}}^{j}=\underbrace{\left(s_{\text {hous }}+s_{\text {oth }} b\right)}_{\equiv " s_{y} "} \hat{p}_{\text {hous }}^{j}+s_{\text {oth }} e^{j} .
$$

Putting the parameters together, the cost-of-living differential is best predicted by weighing $\hat{p}^{j}$ with $s_{y}=0.362$, whereby non-housing goods account for $s_{\text {oth }} b / s_{y}=41$ percent of cost-of-living differences. Since the $R^{2}=0.66$ implies that two thirds of non-housing costs are predicted by housing costs, and only 14 percent of all cost-of-living variation is lost by ignoring idiosyncratic differences in the non-housing goods seen in the error term. Low prices that are not accounted for

\footnotetext{
${ }^{10}$ The index for non-housing costs is reweighed using expenditure shared from the CEX. Results using 1999 ACCRA data are almost identical.
} 
by the housing-cost index are then implicit in a higher QOL value. ${ }^{11}$

\subsection{The Share of Income from Labor}

Conceptually, $s_{w}$ accounts for the fraction of a household's income that depends on its location through local wages. Non-labor income sources - such as from assets or family transfers - are location independent. Even the value of a migrant's home equity is effectively location independent, since the price it can be sold for does not depend on where the migrant moves to. Previous QOL studies have typically determined only the ratio $s_{w} / s_{y}$ by assuming that each household supplies one full-time/full-year worker and divided the ratio by average household rent, producing values between 2.9 and 4.5, although there are typically 1.3 workers per household. Households vary in the share of income they earn from labor, but on average $s_{w}$ is about 75 percent (Krueger 1999). This is corroborated by data in the Survey of Consumer Finances (SCF). In 2001, households received 69.3 percent of income from wages, and 11.7 percent from "business, farm, and self-employment," some of which is derived from labor. Together, $s_{w}=0.75$ and $s_{y}=0.36$ imply that the relative weight of wages relative to housing costs in calculating QOL is $s_{w} / s_{y}=2.08 .^{12}$

\subsection{Federal Taxes and Deductions}

Federal taxes reduce the net income households gain from moving to a city offering higher wages. As fully explained in Albouy (2009a), to calculate the effective tax rate on inter-city wage differ-

\footnotetext{
${ }^{11}$ Gabriel, Mattey, and Wascher (2003) use the ACCRA data directly. Because the data do not cover enough cities, the authors cannot create individual city rankings, and instead perform their analysis by state. They claim that cost-ofliving differences within state should be small relative to differences between states, although this may be problematic in large states such as California, Illinois, Michigan, and New York. According to my calculations, the authors used an effective $s_{\text {hous }}=0.22$ and $s_{\text {oth }}=0.38$, leading to an effective $s_{y}$ of approximately 0.27 , quite similar to the other literature. Carrillo, Early, and Olsen (2010) construct a price index similar to the one here, but incorporate ACCRA data in cities where it is available. Shapiro (2006) uses a technique similar to the one here except he uses expenditure weights provided by ACCRA.

Moretti (2008) runs a regression like (6) across cities over time using local Consumer Price Index data from major cities,supplied by the Bureau of Labor Statistics. He estimates a larger value of $b=0.35$. Moretti's estimate is somewhat larger than the one here mainly because his CPI expenditure shares do not include income saved or paid in taxes. Once these expenditures are taken into account, the adjusted $b$ is 0.25 .

${ }^{12}$ According to Aizcorbe, Kennickell, and Moore (2003), the average household net worth in 2001, adjusted down for the stock-market bubble, was $\$ 341,300$, f ve times the average family income of $\$ 68,000$. At an annual real interest rate of 5 percent, this is worth $\$ 17,065$, or 25.1 percent of income.
} 
ences, several taxes must be considered. A base federal income tax rate is taken from TAXSIM (Feenberg and Coutts 1993), which for 2000 calculates a marginal rate of 25.1 percent, and applies to the average household, weighted by income. When combined with payroll taxes for Medicare and OASDI - net of marginal benefit from the simulation in Boskin et al. (1987, Table 4) the effective federal tax rate rises to 29.6 percent. ${ }^{13}$ Tax benefit to owner-occupied housing are also accounted for: this serves to effectively reduce the share $s_{y}$. In addition, state tax rates are incorporated to accommodate wage and price differentials within state. Although actual state-tax differentials are calculated from state tax rates and within-state wage and price differentials, total tax differences may be approximated by using $\tau^{\prime}=0.323$ and lowering $s_{y}$ from 0.36 to $0.33 .{ }^{14}$ Overall, taxes lowers the wage-to-housing-cost weight from 2.08 to 1.54.

\footnotetext{
${ }^{13}$ According to the Statistics on Income, although only 33 percent of tax returns itemize, they account for 67 percent of reported Adjusted Gross Income (AGI). Since the income-weighted share is what matters, 67 percent is multiplied by the effective tax reduction given in TAXSIM, in 2000 of 21.6 percent. Thus, on average these deductions reduce the effective price of eligible goods by 14.5 percent. Since eligible goods only include housing, this deduction applies to only 59 percent of home goods. Multiplying gives an effective price reduction of 8.6 percent for home goods. Divided by a federal tax rate of 29.6 percent, this produces a federal deduction level of 29 percent. A move to a high-wage city could potentially increase a household's marginal tax rate. A preliminary adjustment for progressivity used in the second-order approximations in Appendix A.3, suggests that the impact of progressive taxes is very small.

${ }^{14}$ State-tax differentials are computed by multiplying state tax and deduction rates by the wage and price differentials within state and include sales taxes, since these effectively tax labor. At the state level, the average effective marginal tax rate on wages is 6.2 percentage points, although, wage differences within state are only 44 percent as large, on average, as wage differences within the entire country. Quality of life is computed using the augmented formula

$$
\hat{Q}^{j}=\left(1-\delta \tau^{\prime}\right) \cdot s_{y} \hat{p}^{j}-\left(1-\tau^{\prime}\right) s_{w} \hat{w}^{j}+\tau_{S}^{\prime}\left[s_{w}\left(\hat{w}^{j}-\hat{w}^{S}\right)-\delta_{S} s_{y}\left(\hat{p}^{j}-\hat{p}^{S}\right)\right]
$$

where $\delta$ is the effective federal deduction rate and $\tau_{S}^{\prime}$ and $\delta_{S}$ are are marginal tax and deduction rates at the state-level, net of federal deductions, and $\hat{w}^{S}$ and $\hat{p}^{S}$ are the differentials for state $S$ as a whole relative to the entire country. State income tax rates from 2000 are taken from TAXSIM, which, per dollar, fall at an average marginal rate of 4.5 percent. State sales tax data in 2000 is taken from the Tax Policy Center, originally supplied by the Federation of Tax Administrators. The average state sales tax rate is 5.2 percent. Sales tax rates are reduced by 10 percent to accomodate untaxed goods and services other than food or housing (Feenberg et al. 1997), and by another 8 percent in states that exempt groceries, equal to its share of expenditures. State deductions for income taxes are calculated in an equivalent way using TAXSIM data, and also account for how housing expenditures are deducted from the sales tax. State adjustments raise the effective deduction level from 0.29 to 0.31 .
} 


\section{Wage, Housing-Cost, and Quality-of-Life Estimates}

\subsection{Data}

Wage and housing-cost differentials are estimated with the 5 percent sample of the U.S. Census data from the 2000 Integrated Public Use Microdata Series (IPUMS). Cities are define at the Metropolitan Statistical Area (MSA) level using 1999 OMB definitions using consolidated defi nitions (e.g. "San Francisco" includes Oakland and San Jose) so that commuting can be ignored, and grouping non-metropolitan areas within each state. This produces 276 metropolitan areas and 49 non-metropolitan-area groups.

Amenity data, are divided into two categories. Natural amenities are predetermined characteristics from climate and geography, including heating degree days and cooling degree days per year, sunshine, coastal proximity, and average slope of the land. Artificia amenities are determined by local inhabitants, such as restaurants and bars per capita, the Arts \& Culture Index from Places Rated, air quality, and safety. More details are provided in Appendix B.

\subsection{Wage and Housing-Cost Regressions}

Inter-urban wage differentials are calculated from the logarithm of hourly wages for full-time workers, ages 25 to 55. In keeping with Rosen (1979) and his successors, these differentials control for skill differences across cities to provide a meaningful analogue to the representative worker. Log wages are regressed on metro-indicators $\left(\mu^{j}\right)$ and on extensive controls $\left(X_{i}^{w j}\right)-$ interacted with gender - education, experience, race, occupation, industry, and veteran, marital, and immigrant status, in an equation of the form

$$
\ln w_{i}^{j}=X_{i}^{w j} \beta^{w}+\mu^{j}+e_{i}^{w j}
$$

The coefficient $\mu^{j}$ are normalized to have an average of zero and equated with the wage differentials, $\hat{w}^{j}$, interpreted as the causal effect of city $j$ 's characteristics on a worker's wages Accord- 
ingly, city $j^{\prime}$ s average wage, $\overline{\ln w}^{j}=\bar{X}^{w j} \beta^{w}+\mu^{j}$, is the sum of the location effect, $\mu^{j}$, and the composition effect, $\bar{X}^{w j} \beta^{w}$, predicted by local worker characteristics (see Appendix Figure A4). Across metros, the standard deviation of $\overline{\ln w}^{j}$ is 0.149 , which is mainly accounted for by the locational effect, $\mu^{j}$, which has a standard deviation of 0.128 . The standard deviation of $\bar{X}^{w j} \beta^{w}$ is only 0.048, meaning that observed characteristics explain only a limited fraction of wage differences across metropolitan areas . This may be surprising given the evidence on residential sorting (e.g. Epple and Sieg, 1999), although this is focused on sorting within metropolitan areas: sorting across metropolitan areas appears more limited, perhaps because of the complementarity of different labor types within local labor markets. Differences in $\beta^{w}$ by city, which leads to heterogeneity in $\mu^{j}$ by type, are not dealt with until section 5.4, although Appendix Figure A1 shows that location effects are remarkably similar across education groups, meaning the labor skills are somewhat, albeit not completely uniformly priced: these differences are investigated in section 5.4.

The estimates of $\mu^{j}$ may be biased by selection according to unobserved skills: if this causes wages in larger cities to be overestimated, than their QOL will be underestimated, since workers are receiving less actual compensation to live in them. To control for sorting, I re-estimate the location effects dropping all observations from workers who live in metropolitan areas that do not contain their state of birth. The location effects without migrants are almost identical - regressing them on the original effects yields a coefficien statistically indistinguishable from one (1.033, s.e. 0.026), and a root mean squared error of only 0.015 - suggesting that selection effects are unimportant. ${ }^{15}$

Both housing values and gross rents, including utilities, are used to calculate housing-cost dif-

\footnotetext{
${ }^{15}$ Place of birth is not available at the sub-state level. This classificatio of movers follows that of Beaudry, Doms, and Lewis (2010). In the literature, Glaeser and Maré (2001), Moretti (2004), and Baum-Snow and Pavan (2010) argue that the urban-rural wage gap is largely unaffected by selection bias, while Combes, Duranton and Gobillon (2008) argue that it is. The wage differentials could also be too small as some of the worker characteristics controlled for, such as occupation or industry, could depend on where the worker locates, although removing these controls has only a minute effect on the location effects.

Adjustment for unionization rates, which in 2000 range from 34.4 percent MN in Duluth to 0.6 percent in Hickory, NC, was also considered with data from Hirsch and Macpherson (2003). Lewis (1986) concludes that unions raise wages by approximately 15 percent. If higher wages are not absorbed by a higher cost-of-living - perhaps through restricted entry into union jobs - then this could cause after-tax real incomes to be up to 2.5 percent higher in Duluth relative to Hickory for reasons independent of local amenities, causing QOL to be underestimated in highly unionized areas. QOL estimates amended for unionization, are only slightly different than the ones reported. Since it is unclear whether unions actually raise wages (Dinardo and Lee 2004) without raising costs-of-living, the estimates are not adjusted for unionization.
} 
ferentials. To be consistent with previous studies, imputed rents are converted from housing values using a discount rate of 7.85 percent (Peiser and Smith 1985), to which utility costs are added: this makes imputed rents comparable to the gross rents available for rental units. To avoid measurement error from imperfect recall or rent control, the sample includes only units acquired in the last ten years. Housing-cost differentials are calculated in a manner similar to wage differentials, using a regression of gross rents on $\mathrm{fl}$ xible controls $\left(X_{i}^{p j}\right)$ - interacted with tenure - for size, rooms, acreage, commercial use, kitchen and plumbing facilities, type and age of building, and the number of residents per room.

$$
\ln p_{i}^{j}=X_{i}^{p j} \beta^{p}+\nu^{j}+e_{i}^{p j} .
$$

The coefficient $\nu^{j}$ are used as the housing-cost differentials, and are interpreted to measure how much costlier a standard unit of housing in city $j$ is relative to the national average. Unobserved differences in housing quality may bias estimates of $\nu^{j}$, so that places with nicer houses are misperceived to have a higher QOL. Yet the standard deviation of log housing cost is 0.277 log points, while for observable differences it is only 0.073 (see Appendix Figure A4). ${ }^{16}$

\subsection{Calculating and Visualizing Quality-of-Life Estimates}

Figure 1 graphs the wage and cost differentials for different cities, with $\hat{w}$ on the horizontal axis and $\hat{p}$ on the vertical axis. The solid line corresponds to the mobility condition (2),

$$
\hat{p}^{j}=\frac{1-\tau^{\prime}}{s_{y}} s_{w} \hat{w}^{j}+\frac{1}{s_{y}} \hat{Q}^{j},
$$

for cities with an average QOL, i.e. $\hat{Q}^{j}=0$. Along this line, costs rise with wage levels so that after-tax real incomes remain constant, as workers are paying to locate by well-paying jobs. When costs in a city are above this line, the city is inferred to have a higher QOL in proportion to the

\footnotetext{
${ }^{16}$ Since an indicator variable is used to control for rental units, this discount rate only affects the relative valuation of housing to utilities, and not to rental units. Malpezzi, Chun, and Green (1998) argue that housing-price indices derived from the Census perform as well or better than most other indices. I combine housing costs and rents to avoid issues of differing home-ownership rates across metro areas. Appendix B.2 presents evidence that rent and housing-cost differenctials are generally similar in 2000 , except in the costliest cities.
} 
distance from the line.

Table 1 lists wage, housing-cost, and QOL differentials for several metropolitan areas, the nine Census divisions, and for metropolitan areas of different population sizes. Appendix Table A1 presents estimates for all metro and non-metro areas; Appendix Table A2 presents estimates for the states. Pacifi locations score the highest, and other cities in the West do well: Honolulu (\#1), San Francisco (\#4) and San Diego (\#8) are in the top 10; Los Angeles, Seattle, Denver, and Portland are all in the top 40. On the East Coast, Miami (\#39), Boston (\#45), and New York (\#51) are the best large cities. Cities in the Midwest and in the South generally fare less well, although New Orleans and Chicago are above average.

QOL estimates using an (unadjusted) parametrization typical of the previous literature may be visualized using the dashed line in Figure 1, which has slope of 4. Unlike the solid line, the dashed line passes under most of the smaller cities in the sample, giving them a higher inferred QOL than in the adjusted case, and above most of the larger cities, giving them a lower inferred QOL. The adjusted QOL, using the favored parametrization, are graphed against the unadjusted QOL estimates in Figure 2, which displays just how different they are: when weighted by population, the correlation between the estimates is almost zero.

The largest discrepancies are in large cities, where both wages and costs are high, and smaller cities, where the opposite is true. While the adjusted estimates indicate a small positive relationship between population size and QOL, the unadjusted estimates indicate a starkly negative relationship. The unadjusted parametrization overstates the nominal income gain and understates the cost-ofliving loss from moving to larger cities, causing their QOL to be underestimated. ${ }^{17}$

Regressing QOL on wage levels and housing costs predicted by worker and housing composi-

\footnotetext{
${ }^{17}$ Most previous studies used the projection of the unadjusted QOL estimates onto the space of individual amenities used in their regression analysis, a procedure which may have mitigated some of the problems with the unadjusted parametrization. Beeson and Eberts (1989) were the firs authors to use the aggregate QOL measure seen here, although their study was limited to the 35 largest cities, largely obscuring the implied negative relationship between QOL and city size. My analysis with 1980 Census data - the same data used by Blomquist, Berger, and Hoehn (1988), Beeson and Eberts (1989), and Gyourko and Tracy (1991) - suggests that adjusted and unadjusted QOL estimates are more positively correlated in 1980 than in 2000, although the differences in 1980 are still substantial. Adjusted QOL estimates from 1980 still reveal a positive, albeit statistically insignificant relationship between QOL and city size.
} 
tion yields

$$
\hat{Q}^{j}=0.36 \quad \bar{X}^{w j} \beta^{w}-0.43 \quad \bar{X}^{w p} \beta^{p}+e^{j} \quad R^{2}=0.36
$$

The predicted coefficien on $\bar{X}^{w j} \beta^{w}$ is $0.51 \varepsilon_{Q, m}$, where $\varepsilon_{Q, m}$ is the elasticity of QOL with respect to income. Hence, $\varepsilon_{Q, m}$ appears to be positive, but not larger than one, although this may be confounded if skills and QOL are substitutes. The predicted coefficien on $\bar{X}^{p j} \beta^{j}$ is $-\varepsilon_{y, m}$, where $\varepsilon_{y, m}$ is the income elasticity of housing. This value is somewhat below the typical range for $\varepsilon_{y, m}$, between 0.7 and 1.0 (Harmon 1988), but this could reflec that housing and amenities are complements. ${ }^{18}$

\subsection{A Test of the Parametrized Mobility-Condition Slope}

The dotted line in Figure 1, estimated by regressing housing costs on wage level, motivates a test of the parameter choices, as the difference between this line and the calibrated mobility condition implies a statistical relationship between observed wages and unobserved QOL. Write the linear projection of QOL on wages and an incomplete vector of amenities as $\hat{Q}^{j}=\mathbf{Z}^{j} \pi_{Q}+b_{Q} \hat{w}^{j}+\eta^{j}$, where by construction $E\left[\eta^{j} \mid \mathbf{Z}^{j}, \hat{w}^{j}\right]=0$. Then, according to (10), the expectation of $\hat{p}^{j}$ conditional on $\mathbf{Z}^{j}$ and $\hat{w}^{j}$ is

$$
E\left[\hat{p}^{j} \mid \mathbf{Z}^{j}, \hat{w}^{j}\right]=\mathbf{Z}^{j} \pi_{Q}+\left(\frac{1-\tau^{\prime}}{s_{y}} s_{w}+\frac{b_{Q}}{s_{y}}\right) \hat{w}^{j} \equiv \mathbf{Z}^{j} \pi_{Q}+b_{w} \hat{w}^{j}
$$

The coefficien $b_{w}$ is the slope of the mobility condition under the correct parametrization, $(1-$ $\left.\tau^{\prime}\right) s_{w} / s_{y}$, plus a term which depends on the residualized correlation of QOL with wage levels, $b_{Q}$. If $b_{Q}=0$ without any amenity controls, then the mobility condition is given by the regression line. Moreover, any parametrization implies a value of $b_{Q}=s_{y} b_{w}-\left(1-\tau^{\prime}\right) s_{w}$. Estimated values of $b_{w}$

\footnotetext{
${ }^{18}$ If unobserved skills are positively related with observed skills, this regression suggests that unobserved skills may be positively related with QOL, causing QOL differences to be underestimated in cities with greater skills, such as in some larger cities. As QOL and observable housing characterstics are negatively related, QOL may be overestimated in cities with nicer housing, such as in some smaller cities.
} 
and implied values of $b_{Q}$ are reported in table $2 .{ }^{19}$

If QOL could be observed, then a direct regression of (10) would provide an unbiased estimate of $\left(1-\tau^{\prime}\right) s_{w} / s_{y}$, as $b_{Q}$ would be reduced to zero. Since QOL is unobserved, the best approach is to control for observed amenities to minimize $b_{Q}$, and to test whether the estimated $b_{w}$ is different from the parametrized slope. The test results shown in columns 3 and 4 of Table 2 reveal that estimates of $b_{w}$ are close to the adjusted parametrization, and far from the unadjusted one, which can only be correct if unobserved amenities are correlated very negatively with wage levels. ${ }^{20}$

\subsection{Relationship with Other QOL Measures}

Another check on the validity of the revealed-preference QOL estimates is to consider how they correlate with city rankings based on other methods. As explained in Becker et al. (1987), the Places Rated Almanac ranks cities along nine dimensions: climate, crime, health care, transportation, education, arts and culture, recreation, housing costs, and job outlook. These nine rankings are averaged geometrically to determine an overall "livability" ranking. The rankings are sensitive to many subjective decisions, but do have a certain plausibility that account for their popularity. As seen in Panel A of Table 3, the correlation between the Places Rated and adjusted QOL rankings is positive, while it is negative with the unadjusted QOL ranking. An issue with the "livability" index is that it incorporates cost-of-living and job-market components that do not belong in the revealed-preference QOL ranking. The economic QOL measure assumes that all cities are equally good once costs-of-living and labor markets are accounted for, while Places Rated looks for cities that offer the most valuable amenities at the lowest cost, similar to the "Best Value" recommendations seen in Consumer Reports. When recalculated to remove these components, the Places Rated ranking is correlated more positively with the adjusted ranking and more negatively with the

\footnotetext{
${ }^{19}$ The restriction $b_{Q}=0$ is implicitly assumed but not theoretically justifie by Glaeser, Kolko, and Saiz (2002)

${ }^{20} \mathrm{It}$ is worth noting that the parameters were intially chosen in order to predict the effect of federal taxes in Albouy (2009a), and not to estimate QOL. Also, most of the amenity measures in the regression were chosen prior to the development of this test. Thus, this test does not suffer from conventional pre-test bias.
} 
unadjusted ranking. $^{21}$

I also construct a ranking based on stated preferences from the Pew Research Center by Taylor et al. (2009). Respondents were named 10 cities in random order and asked "As I read through the following places, just tell me your firs reaction: would you want to live in this city or its surrounding metropolitan area or NOT want to live there?" The percent of "yes" and "no" responses are used to construct stated-preference rankings of 28 cities, which, as seen in Panel B of Table 3, are positively correlated with both QOL rankings, especially the adjusted one. ${ }^{22}$

The QOL estimates here also differ substantially from other revealed-preference estimates in the economic literature. As seen in Panel C, at the state level, the QOL estimates in Gabriel, Mattey and Wascher (2003) are correlated weakly to the adjusted estimates, but strongly to the unadjusted ones. As seen in Panel D, at the metro level, the QOL estimates in Chen and Rosenthal (2008) are correlated positively with the adjusted estimates and even more so with the unadjusted estimates, especially when non-metro areas are included. The similarity with the adjusted estimates arises as Chen and Rosenthal use a wage/housing cost weight of 2.86 - the smallest in the previous literature - although they still rank large cities like New York and Chicago well below average. ${ }^{23}$

\footnotetext{
${ }^{21}$ An additional support for the adjusted QOL estimates is provided by Carlino and Saiz (2008), who fin that the adjusted QOL estimates are positively correlated with the number of tourist visits in a city.

${ }^{22}$ This ranking has shortcomings as they are from 2008 and respondents were not told to ignore labor-market opportunities or cost-of-living, and all of the listed cities are fairly large. Nonetheless, the answers are likely to reflec cities that respondents consider to have an attractive QOL.

${ }^{23}$ Gabriel, Mattey, and Wascher (2003) use an effective wage/housing-cost weight of 3.72, taking into account their use of ACCRA data for non-housing costs. Shapiro (2006) takes into account non-housing costs, but never provides QOL measures.
} 


\section{Quality of Life and Individual Amenities}

\subsection{Two-Step Estimates}

Based on hedonic theory, the QOL values may be used to estimate how much value households put on particular amenities from a second-step regression

$$
\hat{Q}^{j}=\sum_{k} \pi_{k}^{Q} Z_{k}^{j}+\varepsilon^{Q j}
$$

where $\pi_{k}=-(\partial E / \partial Q)\left(\partial \tilde{Q} / \partial Z_{k}\right) / \bar{m}$ measures the fraction of gross income a household is willing to pay for one more unit of amenity $k$. Multiplying this coefficien by average gross household income $(\$ 68,000$ in 2000$)$ produces the dollar value. The residual $\varepsilon^{Q j}$ results from measurement error, unobserved amenities, mis-specification and unobserved differences in housing quality and worker skills. The separate contribution of wage and housing-cost effects are presented from regressions

$$
\hat{w}^{j}=\sum_{k} Z_{k}^{j} \pi_{k}^{w}+\varepsilon^{w j}, \hat{p}^{j}=\sum_{k} Z_{k}^{j} \pi_{k}^{p}+\varepsilon^{p j}
$$

where the model implies that $\pi_{k}^{Q}=s_{y} \pi_{k}^{p}-\left(1-\tau^{\prime}\right) s_{w} \pi_{k}^{w}$.

Beginning with Rosen (1979), previous studies have typically estimated amenity values using individual-level wage and housing-cost equations like (8) and (9), with a vector of amenity variables in place of MSA dummy variables, essentially substituting in (13). This one-step method produces estimates of $\pi_{k}^{p}$ and $\pi_{k}^{w}$ similar to the two-step method outlined above when the same amenities and weights are used in both equations (Ameniya 1978). The QOL estimates reported are typically from the prediction $\hat{Q}^{j *}=\sum_{k} \hat{\pi}_{k}^{Q *} Z_{k}^{j}$, which depends on the amenities chosen and ignores the residual, $\varepsilon^{Q j}$. Issues around clustering can cause standard errors from the one-step method to be too small (Gyourko, Kahn, and Tracy 1999), while the two-step method provides conservative standard errors (Wooldridge 2003) and a coefficien of multiple correlation (R-squared), describing how much QOL is explained by measured amenities. ${ }^{24}$

\footnotetext{
${ }^{24}$ Clustering at the city level in the one-step method produces standard errors for amenity values similar to those in
} 
Whatever the specifi method, inferring specifi amenity values with cross sectional data faces many conventional potential pitfalls. There is a high degree of collinearity between the amenity variables, making it difficul to obtain precise estimates for a reasonably large set of variables. Unmeasured amenities, such as a city's downtown charm, may contribute to omitted variable biases. Furthermore, artificia amenities may be highly endogenous, subjecting their estimated values to additional skepticism. Yet, oftentimes there is no other recourse, due to the unavailability of natural experiments and confounding factors in the dynamics of urban price and wage changes over time.

\subsection{Dependence of Quality of Life on Amenities}

Table 4 presents amenity-value estimates, with each measure signed so that each is an amenity, which a priori should yield a positive valuation. Column 1, which includes only natural amenities, estimates that households pay 0.89 percent of income to live in areas with 1000 fewer heating degree days, which translates to 3.9 percent of income for all excessive cold in a typical area; for cooling degree days the estimate is 3.13 , which translates to 4.0 percent of income to eliminate a typical area's excessive heat. Households pay 2.9 percent of income to live in areas where 10 percent more of the day is sunny (1.29 standard deviations), 1.7 percent of income to live in areas with a standard deviation higher inverse distance to the coast, and 2.7 percent of income to live in areas where the average slope is 10 percent higher. It is questionable whether these measures reflec true valuations of these amenities, but they seem plausible and it is remarkable that these f ve variables explain 70 percent of the variation in the adjusted QOL measure. As seen in columns 2 and 3, the amenity variables are better at explaining housing costs than wages. Estimates with the unadjusted QOL measures in column 4, more reliant on wages, explain less and lack plausibility, with households paying to live in hot areas away from the coast, without caring significantl about cold or sunshine..$^{25}$

the two-step method. Technically, the cities should be weighted by the predicted income of the inhabitants, although for transparency and simplicity, I weight them by population here, which produces almost identical results.

${ }^{25}$ Additional climate measures, such as annual rainfall, wind speed or humidity are generally not significan in these regressions. Separating Great Lake coasts from salt-water coasts results in slightly higher, but insignif cantly different, 
Columns 5 through 6 add artificia amenities. The adjusted estimates show that households have a high willingness-to-pay to live in areas with many eating and drinking establishments, arts and culture, and better air quality. However, there is no significan association between estimated QOL and indices of either property or violent crime. This demonstrates the limitations of the hedonic approach, especially for amenities that vary significantl within a metropolitan area. ${ }^{26}$ Nevertheless, the estimates appear better adjusted, as they fin coasts, culture, and sunny, temperate climates to be goods. ${ }^{27}$

\subsection{Amenities and City Size}

Urban amenities and disamenities depend largely on urban population and density, including safety, cleanliness, and cultural and consumption (Rosen 1979; Glaeser, Kolko and Saiz 2001). Including a metropolitan population variable in (12) helps to account for the amenities, observed or not, that are correlated with or endogenously result from city size. Columns 1 and 2 in Panel A of Table 5 report that population is related positively to adjusted QOL, but very negatively to unadjusted QOL, demonstrating the anti-urban bias in the previous literature. Controlling for amenities in columns 3 through 6 causes the relationship to disappear with adjusted QOL, but not with unadjusted QOL. The positive relationship between adjusted QOL and population is due to cities being larger where there is a nicer climate and geography, reflectin the household location choices noted by Rappaport and Sachs (2003) and Rappaport (2007). Using a density measure in place of a density measure in Panel B, produces rather similar results, albeit slightly in favor of denser cities being nicer places to live. ${ }^{28}$

\footnotetext{
valuations for sea coasts.

${ }^{26}$ Rosenthal and Ross (2010) argue that economically vibrant areas are favored targets for crime, further complicating the ability to identify the value of safety from cross-sectional data.

${ }^{27}$ Commuting time is not entered as an independent variable as this is an endogenous variable from the individual's viewpoint. Workers should be willing to commute longer hours in order to live in a more desirable metropolitan area. Empirically, the elasticity of commuting time with respect to population size is roughly 0.10 . Assuming commuting takes 10 percent of the working day and monetary costs are 5 percent of income, this implies that commuting increases the elasticity of QOL with respect to population by 0.015 .

${ }^{28}$ While this analysis find that there is no empirical relationship between city size and QOL it does not definit vely prove that there is no causal relationship. The slightly positive relationship between QOL and population is reduced to zero once natural amenities are controlled for, as the population size endogenously depends on available amenities. It
} 


\section{Taste Heterogeneity and Imperfect Mobility}

\subsection{Amending the Basic Model}

There are many ways to model heterogenous households, many of them perplexing. But it is possible to incorporate a continuous form of heterogeneity into the model that is tractable and useful for understanding a number of phenomena. Suppose that QOL in city $j$ is dependent on a universal component $Q^{j}$, and a household-specifi component, $\xi_{i}^{j}$, so that overall QOL for household $i$ in city $j$ is $Q_{i}^{j}=\underline{Q}^{j} \xi_{i}^{j}$. Furthermore, assume that $\xi_{i}^{j}$ is Pareto distributed with parameter $1 / \psi: F\left(\xi_{i}^{j}\right)=1-\left(\underline{\xi} / \xi_{i}^{j}\right)^{1 / \psi}, \xi_{i}^{j} \geq \underline{\xi}$. A higher $\psi$ implies greater heterogeneity in preferences, with $\psi=0$ corresponding to the model with homogenous preferences. For simplicity, assume that the outside utility for households is given by a constant $\bar{u}$. For some given constant, $N_{\max }^{j}$, there exists a marginal household $k$ with taste parameter $\xi_{k}^{j}$, so that the population in city $j$ is

$$
\begin{gathered}
N^{j}=N_{\max }^{j} \operatorname{Pr}\left(\xi_{i}^{j} \geq \xi_{k}^{j}\right)=N_{\max }^{j}\left[1-F\left(\xi_{k}^{j}\right)\right]=N_{\max }^{j}\left(\underline{\xi} / \xi_{k}^{j}\right)^{1 / \psi} . \text { Hence, } \\
\log N^{j}=\ln N_{\max }^{j}+\frac{1}{\psi}\left[\log \underline{\xi}-\log \xi_{k}^{j}\right] .
\end{gathered}
$$

Fully differentiating the equilibrium condition (1), treating $N$ as an endogenous variable, and noting that (14) implies $\hat{N}^{j}=-\hat{\xi}_{k}^{j} / \psi$, leads to an extended version of equation (2):

$$
s_{y} \hat{p}^{j}-s_{w}\left(1-\tau^{\prime}\right) \hat{w}^{j}=\underline{\hat{Q}}^{j}-\psi \hat{N}^{j}
$$

This says that the marginal willingness-to-pay to live in city $j$, given by the left-hand side, decreases by $\psi$ percent of income, when the population increases by one percent. $\psi$ may parametrize household mobility, with $\psi=0$ and $\psi=\infty$ characterizing perfect mobility and im-

is conceivable that, holding natural amenities fi ed, adding population to existing cities could lower QOL by increasing artificia urban disamenities. For this hypothesis to hold, there should be some unobserved, presumably natural, amenity that when controlled for would make the QOL-population gradient negative. Nevertheless, if this hypothesis is true, then controlling for artificia amenities should cause the population-QOL gradient to rise, which it did not appreciably, as controlling for urban disamenities should have made larger cities more attractive. Furthermore, since the measured amenities explain much of the existing variation in QOL, it is difficul to imagine that there is such an important unmeasured amenity that is unaccounted for. 
mobility, respectively. Rearranging (15) provides an upward-sloping local-labor supply curve in terms of wages and QOL, as well as a downward-sloping demand curve in terms of local prices: $\hat{N}^{j}=\left[s_{w}\left(1-\tau^{\prime}\right) \hat{w}^{j}-s_{y} \hat{p}^{j}+\hat{Q}^{j}\right] / \psi$. The more willingness-to-pay to live in a city varies across individuals, the less elastic is its labor supply, as inframarginal households need to be paid an increasing premium to move to it.

\subsection{Population Level and Density}

How the universal QOL component, $\underline{\hat{Q}}^{j}$, may be measured depends on how $\hat{N}^{j}$ is interpreted. Interpreting $\hat{N}^{j}$ as the population deviation from the national average, whereby $N_{\max }^{j}$ is constant across cities, is a natural way to account for preference heterogeneity. If a small number of individuals enjoy an amenity, say a coastal location, the few who enjoy it will likely have the highest marginal willingness-to-pay for it. Such is seen in discrete-choice models - which, as shown in Appendix A.4, can produce equation (15) - since they are identifie off of the population shares residing in different locations. This implies that more populous cities offer a higher QOL than is implied by wages and costs alone: if two cities offer the same wages and costs, the more populated city is deemed the one most amenable to the typical individual.

When considering tastes for city size, it may be better to characterize cities according to population size alone as the taste components, $\xi_{i}^{j}$, should be correlated across cities of the same size. In this case, Zipf's (1949) law for cities - the empirical findin that a city's population is inversely proportional to its rank, confirme for the U.S. by Ioannides and Overman (2003) - implies that the population is uniformly distributed across city sizes. Thus, adjusting for heterogenous preferences does not change the conclusion that households are, on the margin, indifferent over city sizes.

Regressions of city size on amenities, seen in column 1 of Table 6 , show a positive relationship between population size and coastal proximity, although that is the only significan natural amenity. Due to what are surely endogenous processes, there are also positive relationships with arts and culture, air pollution, and violent crime. The relationship with property crime is negative, as it is with restaurants and bars per capita, although both estimates are susceptible to division bias, since 
the measures are per capita. Since the land areas of cities increase with size, it may be preferable to consider the relationship between population density and amenities, as this effectively treats each acre of land as a separate choice. As seen in column 2, population density is positively related to both sunshine and coastal proximity, as well as arts and culture, but not significantl to the other variables.

The use of population levels or densities to value amenities is problematic if place-specifi tastes depend on local attachments, which are state dependent on previous population levels. These levels depend on previous local employment and housing opportunities, as well as amenities. Thus, Detroit may have a large population not because it offers a high QOL relative to its real-wage level, but because of its once vibrant economy. Existing residents have attachments to the area, but these are not of value to potential migrants.

\subsection{Population Growth and Labor-Market Disequilibrium}

In certain applications, $\hat{N}^{j}$ is better measured as the deviation relative to a previous population level, say where $N_{\max }^{j}$ is determined by previous population levels. Viewed dynamically, migration fl ws are expected to occur to cities where real wages are high relative to universal QOL, i.e. to cities that are "under-priced" relative to the amenities they offer. This disequilibrium may reflec factor imbalances that will be corrected for. In principle, $\psi$ should fall towards zero as the timeperiod in question expands: location-specifi tastes are more homogenous over the long run, as households adapt to local amenities, lose attachments to old locations, and amortize moving costs over a longer time period. Indeed, most Americans originate from populations in the Old World that migrated less than two centuries ago. But in the shorter-run, households must be offered a real-wage premium to move, and a larger premium attracts more migrants. It may also reflec that recent migrants may not receive as much of a premium as existing residents, at least at first This insight provides a micro-foundation for the disequilibrium model in Greenwood et al. (1991), whereby a city's QOL is measured through a weighted combination of its population growth and 
minus its real income. ${ }^{29}$

Figure 3 illustrates how city growth may be used to amend QOL estimates by plotting population changes between 1980 and 2000 against the original adjusted QOL estimates. This adjustment increases the value of fast-growing cities, like Las Vegas, Phoenix, and Atlanta. Slower-growth cities like Pittsburgh, Chicago, and New York, should have their QOL estimates lowered as workers there accept a real wage discount to preserve their local attachments. The positive correlation between growth rates and the adjusted QOL measures suggests that QOL differences may be larger than the original measure and that households may have an increasing preference for non-market goods. Gibrat's law for cities (Gabaix 1999) - the empirical findin that population growth rates are independent of city size - implies that adjusting for population growth should not bias preferences towards or against city size.

A regression based on population growth in Column 3 of Table 6 find that warm areas are gaining population, consistent with Glaeser and Tobio (2007), so that aversion to heat may be overvalued in Table 4. Sunny and sloped areas are also growing, meaning those amenities deserve higher values. Coastal proximity is negatively related to growth, as coastal areas have largely fille up: thus, as implied by the "superstar cities" hypothesis of Gyourko, Mayer and Sinai (2006) - amenities in tight supply see their marginal valuation rise at a faster rate than their average valuation, as the national population grows. Growth rates are positively related to arts and culture, and negatively with violent crime, although these effects could be endogenous. Yet, while growth should increase pollution, populations are migrating towards areas with cleaner air. ${ }^{30}$

Combining growth rates with wage and housing costs to measure QOL and amenity values requires determining the weight $\psi$. This is a behavioral parameter that can be estimated off of the

\footnotetext{
${ }^{29}$ Greenwood et al. (1991) separately estimate actual and equilibrium real wages, and fin that in only 7 out of 51 cases are the two the statistically different at the 90 percent significanc level (Hunt 1993). Their QOL estimates depend inversely on real wages and emigration, but are not adjusted for federal taxes or non-labor income. They are higher for Arkansas, Mississippi, and South Dakota than they are for Hawaii and California.

${ }^{30}$ Quigley and Raphael (2005), Glaeser, Gyourko, and Saks. (2005), and Gyourko, Mayer, and Sinai (2006) argue that supply restrictions on housing in areas, such as California, have caused housing costs in these areas to increase disproportionately without wage or amenity improvement. Yet, in the traditional Rosen-Roback model with homogenous households, supply restrictions in a single city raise housing costs nationwide but do not increase the relative price in that city, holding wages constant, although they do reduce local population.
} 
impact of labor demand shocks on wages and housing costs, assuming that QOL are unaffected by those shocks. Estimates in this style from Notowidigdo (2010) show wages and housing costs move closely together, implying small values of $\psi$, around 0.05 or below, although an extreme value of $\psi=0.1$ is used here for illustration and to account for possible QOL endogeneity. ${ }^{31}$ Dashed lines tracing out cities with the same amended QOL are drawn in Figure 3. Column 4 of Table 5 presents amended amenity valuations using a value of $\psi=0.1$, which show a somewhat more balanced dislike for heat relative to cold, stronger tastes for slopes, culture, and air quality, and weaker tastes for coastal location. Interestingly, these reduced-form results reflec core finding in the structural migration models of Bishop (2008) and Sinha and Cropper (2009), who fin very large valuations for clean air and warm weather, respectively, as their estimation technique puts weight on growth (i.e. $\psi$ ) that is quite large relative to wages and costs.

\subsection{Preference Heterogeneity across Observed Types}

Several studies have given considerable attention to how households with different skills value amenities differently. Differencing (15) for two different household types

$$
\left(1-\tau_{1}^{\prime}\right) s_{w 1} \hat{w}_{1}^{j}-\left(1-\tau_{2}^{\prime}\right) s_{w 2} \hat{w}_{2}^{j}=-\left(\underline{\hat{Q}}_{1}^{j}-\underline{\hat{Q}}_{2}^{j}\right)+\left(s_{y 1}-s_{y 2}\right) \hat{p}^{j}+\left(\psi_{1} \hat{N}_{1}^{j}-\psi_{2} \hat{N}_{2}^{j}\right)
$$

The standard case assumes $\psi_{1}=\psi_{2}=0$, so that type 1 is paid a premium relative to type 2 , i.e. $\hat{w}_{1}^{j}>\hat{w}_{2}^{j}$ if it i) enjoys the amenities of the city less, $\hat{Q}_{1}^{j}<\hat{Q}_{2}^{j}$; ii) is in a costlier city and has a higher housing expenditure share, $s_{y 1} \hat{p}^{j}>s_{y 2} \hat{p}^{j}$; and also if it iii) faces a higher marginal tax rate, $\tau_{1}^{\prime}>\tau_{2}^{\prime}$; or iv) receives a smaller share of income from labor, $s_{w 1}>s_{w 2}$. Definin $\tilde{s}_{w} \equiv\left(1-\tau^{\prime}\right) s_{w}$

\footnotetext{
${ }^{31}$ Notowidigdo (2010, Tables 2 and 4) find that over 10 years a positive employment shock that leads to 1.8 point increase in population, leads to a 0.52 point increase in wages and a 0.80 increase in housing costs. Using the calibration here, this is only a 0.01 increase in real income. The effect becomes larger with the size of the shock, increasing to 0.03 with a positive shock of one standard deviation. The linearized derivative, a good indicator of $\psi$, is approximately 0.05 . However, if QOL improves differentially in growing areas, which it may, this parameter will be biased downwards.
} 
and assuming $\psi_{1}=\psi_{2}=\psi$, we can rearrange (16) into the regression equation

$$
\tilde{s}_{w}\left(\hat{w}_{2}^{j}-\hat{w}_{1}^{j}\right)=\left(\tilde{s}_{w 1}-\tilde{s}_{w 2}\right) \hat{w}^{j}+\left(s_{y 2}-s_{y 1}\right) \hat{p}^{j}+\left(\underline{\hat{Q}}_{1}^{j}-\underline{Q}_{2}^{j}\right)-\psi\left(\hat{N}_{1}^{j}-\hat{N}_{2}^{j}\right)+\varepsilon^{j}
$$

where $\varepsilon^{j}=\left(\tilde{s}_{w}-\tilde{s}_{w 2}\right)\left(\hat{w}_{2}^{j}-\hat{w}^{j}\right)-\left(\tilde{s}_{w}-\tilde{s}_{w 1}\right)\left(\hat{w}_{1}^{j}-\hat{w}^{j}\right)$ is orthogonal to $\hat{w}^{j}$ by construction. ${ }^{32}$ The left-hand side of (17) expresses the relative willingness-to-pay of type 1 households, as a fraction of total income, for overall wage levels, $\hat{w}^{j}$, cost levels, $\hat{p}^{j}$, and amenities. The last term, $-\psi\left(\hat{N}_{1}^{j}-\hat{N}_{2}^{j}\right)$, expresses how higher relative wages elicits higher relative supplies. A positive $\psi$ may be rationalized even in a static setting, if workers of different types are attached to each other, and costly to separate. For instance, a family may have workers with different skills; see also Heckman and Scheinkman (1987).

This model is illustrated here with two worker types: college (type 1) and high-school (type 2). Figure 4 graphs relative differences in their wages, $\hat{w}_{1}-\hat{w}_{2}$, and quantities, $\hat{N}_{1}^{j}-\hat{N}_{2}^{j}$, the latter measured through a Katz and Murphy (1992) index. ${ }^{33}$ According to statistics from the SCF and CEX, high-school workers get a greater share of their income from wages, with $\tilde{s}_{w 1}-\tilde{s}_{w 2}=$ -0.120 , and spend a greater share of their income on housing and local goods, with $s_{y 2}-s_{y 1}=$ 0.061. ${ }^{34}$ Thus, they need to be paid relatively more to live in expensive areas, but will accept less of a premium in areas where overall wage levels are high. Column 1 of Table 7 demonstrates that this prediction is largely upheld. In principle, a regression of (17) should also be able to identify

\footnotetext{
${ }^{32}$ This follows from $\hat{w}^{j}=\lambda \hat{w}_{1}^{j}+(1-\lambda) \hat{w}_{2}^{j}$ and $\tilde{s}_{w}=\lambda \tilde{s}_{w 1}+(1-\lambda) \tilde{s}_{w 2}$ for the same constant $\lambda$, which is true for $\lambda=0.55$.

${ }^{33}$ The Katz-Murphy Index determines the number of college (high school) workers by giving workers a weight of $1(0)$ with a college degree, 0.38 (0.67) with some college, 0 (1) with a high-school degree, and -0.39 (1.11) with less than a high-school degree. The weights for workers with some college or less than high school, are determined by regressing their location effects on the location effects for college and high-school workers. The weights are somewhat close to Katz and Murphy's, despite the fact that the variation of wages is across metros, rather than across years.

${ }^{34}$ According to the $2000 \mathrm{CEX}$, the gross expenditure share on shelter and utilities is 0.191 for college graduates and 0.227 for high-school graduates. If we inflat both of these shares by 1.69 to include non-housing goods, the shares become 0.324 and 0.385 . In the SCF, the ratio of family net worth to income for college-headed familes is 1.69 times that of high-school-headed families, producing, $s_{w 1}=0.706$ while $s_{w 2}=0.822$. According to figure in Piketty and Saez (2007), marginal federal taxes are about 2.5 percentage points lower for high-school incomes and 2.5 points higher for college incomes. Thus $\left(1-\tau_{1}^{\prime}\right) s_{w 1}=0.460$ and $\left(1-\tau_{2}^{\prime}\right) s_{w 2}=0.577$. Notowidigdo (2010, Table 3) does not fin significantl different effects of employment shocks on college and non-college workers, implying similar values for $\psi_{1}$ and $\psi_{2}$, although the model here refers to levels and not changes. Berry and Glaeser (2005) document that human capital differences across cities doubled between 1970 and 2000.
} 
$\psi$, and relative valuations for amenities, $\underline{\hat{Q}}_{1}^{j}-\underline{\hat{Q}}_{2}^{j}$. With these additional variables in column 2 , the coefficient on $\hat{w}^{j}$ and $\hat{p}^{j}$ are both very close to their predicted values. ${ }^{35}$ The estimate of $\psi$ is negative, but small and insignificant This relative valuation for amenities are curious, suggesting that college-educated households seem to have a weaker aversion to cold and a weaker taste for coastal proximity, although these estimates could be biased by omitted amenities. ${ }^{36}$ The coefficien on property crimes that high-school educated households have a greater aversion to property crime, perhaps as they are more likely to locate in neighborhoods where it is concentrated.

A limitation with the above analysis is that relative wages depend only on labor-supply factors. To consider demand factors, assume that aggregate labor input in city production may be aggregated according to a constant elasticity of substitution, $\sigma$, with aggregate labor $N^{j}=$ $\left[\sum_{g}\left(A_{g}^{j} N_{g}^{j}\right)^{(\sigma-1) / \sigma}\right]^{\sigma /(\sigma-1)}$, where $A_{g}^{j}$ denotes the productivity of type $g$ in city $j$. Then, relative labor demand is decreasing in the relative wage and increasing with relative productivity, if $\sigma>1$ :

$$
\hat{N}_{1}^{j}-\hat{N}_{2}^{j}=-\sigma\left(\hat{w}_{1}^{j}-\hat{w}_{2}^{j}\right)+(\sigma-1)\left(\hat{A}_{1}^{j}-\hat{A}_{2}^{j}\right)
$$

With (16), relative wage and quantity differences are determined in the case where $s_{y 1}=s_{y 2}$ and $\tilde{s}_{w 1}=\tilde{s}_{w 2}$ :

$$
\begin{aligned}
\hat{w}_{1}^{j}-\hat{w}_{2}^{j} & =\frac{1}{\tilde{s}_{w}+\psi \sigma}\left[\psi(\sigma-1)\left(\hat{A}_{1}^{j}-\hat{A}_{2}^{j}\right)-\left(\underline{\hat{Q}}_{1}^{j}-\underline{Q}_{2}^{j}\right)\right] \\
\hat{N}_{1}^{j}-\hat{N}_{2}^{j} & =\frac{1}{\tilde{s}_{w}+\psi \sigma}\left[\tilde{s}_{w}(\sigma-1)\left(\hat{A}_{1}^{j}-\hat{A}_{2}^{j}\right)+\sigma\left(\underline{\hat{Q}}_{1}^{j}-\underline{\hat{Q}}_{2}^{j}\right)\right]
\end{aligned}
$$

Relative productivity differences appear in wage differences only if $\psi>0$ and $\sigma \neq 1$, and become dominant as $\sigma$ or $\psi \rightarrow \infty$. Both relative productivity and QOL differences impact labor quantities positively when $\sigma>1$, but become less important as $\psi \rightarrow \infty$.

The lack of a clear positive or negative relationship in Figure 4 between relative wages and

\footnotetext{
${ }^{35}$ Using 1990 data, Black, Kolesnikova, and Taylor (2009) fin similar results for $s_{y}$, but do not calibrate the prediction or control for overall wage levels. The prediction does not hold with 2000 data without controlling for the overall wage level.

${ }^{36}$ Without conditioning on wages and costs, coastal proximity has a positive correlation with relative college-worker willingness-to-pay as well as supply.
} 
supplies across cities suggests that neither supply nor demand factors dominate their relationship. The figur includes an upward-sloping hypothetical relative indifference curve, using $\psi=0.1$ and $\tilde{s}_{w}=0.51$ in $\hat{w}_{1}-\hat{w}_{2}=\left(\psi / \tilde{s}_{w}\right)\left(\hat{N}_{1}-\hat{N}_{2}\right)$, derived from (16) assuming equal prices, costs, and amenity values: areas to the lower-right of this relative supply curve are predicted to have higher costs, lower overall wages, or better amenities for college relative to high-school workers. A downward-sloping hypothetical substitution locus for firm is also drawn, using $\sigma=2$ using, $\hat{w}_{1}-\hat{w}_{2}=-(1 / \sigma)\left(\hat{N}_{1}-\hat{N}_{2}\right)$, derived from (18) assuming equal productivities: cities to the upper-right of this relative demand curve may offer productive advantages to college workers. ${ }^{37}$ Notice that if $\psi=0$, the supply curve is horizontal, meaning that college-educated households have stronger preferences for Las Vegas and Texarkana, and weaker preferences for Washington, DC and New York. The sloped line with $\psi=0.1$ reverses these relative preferences, making them more plausible, and attributes the relative wage differences to high-school workers being relatively productive in Las Vegas and less so in Washington. ${ }^{38}$

The amended valuations in column 4 combine the valuations in column 2 with the relative supply amounts in column 3 , attaching a weight of $\psi=0.1$ to them, assuming this weight was incorrectly estimated in column 2 . These results mainly reinforce previous ones, but also strengthen the evidence that college-educated workers have a greater demand for arts and culture and clean air, although they could be affecting their supply as well as their demand.

\footnotetext{
${ }^{37}$ The $\sigma$ elasticity is calibrated to model productivity feedbacks. If productivity depends on absolute productivity differences and the relative supply of workers of one's own type: $\hat{A}_{1}^{j}-\hat{A}_{2}^{j}=\beta_{A}\left(\hat{N}_{1}^{j}-\hat{N}_{2}^{j}\right)+\left(\underline{\hat{A}}_{1}^{j}-\underline{\hat{A}}_{2}^{j}\right)$. then a feedback-corrected elasticity of substitution is $\sigma^{*}=\sigma /\left[1-\beta_{A}(\sigma-1)\right] . \sigma^{*}=2$ is consistent with $\sigma=1.4$ from Katz and Murphy (1992) and $\beta_{A}=0.075$. Berry and Glaeser (2005) present a model where relative productivity differences affect relative wage levels but implicitly assume $\sigma=\infty$. Positive feedbacks in prefernces can increase the tendency to sort, if $\underline{\hat{Q}}_{1}^{j}-\underline{\hat{Q}}_{2}^{j}=\beta_{Q}\left(\hat{N}_{1}^{j}-\hat{N}_{2}^{j}\right)+\left(\underline{\underline{Q}}_{1}^{j}-\underline{\underline{Q}}_{2}^{j}\right)$, then a feed-back correccted $\psi^{*}=\psi-\beta_{Q}$.

${ }^{38}$ Another possibility is that $\psi>0$ controls for selection bias if worker types with better unobserved skills sort preferentially into areas where a greater number of them live. For example, New York may have a high measure of relative wages for college workers because of sorting rather than supply and demand factors, which is reflecte in the relatively larger supply of these workers.
} 


\section{Conclusion}

Neither population size nor density appear to negatively impact American QOL in modern times: it appears that urbanization's amenities largely compensate for its disamenities. Thus, there is no reason to see urbanization as lowering economic welfare, undermining arguments for policies to disperse the population to mitigate negative urban externalities. While most policy-makers are concerned about improving the amenities in their cities, the fact that most QOL differences are explained by natural amenities suggests that policy-makers should also consider ways to help households move to places with greater sun, mountains, coastal proximity, or temperate seasons. For instance, they could consider relaxing restrictions to residential development on lands wellendowed by nature, as higher densities are unlikely to reduce, and may even improve, local QOL.

Methodologically, it is encouraging that revealed-preference estimates of QOL are not at odds with popular notions of what cities are nice places to live, although hedonic methods suggest that certain amenities, such as climate and coastal proximity, may deserve greater weight than popular rankings may put on them. This work may renew confidenc that revealed-preference and hedonic methods, when properly applied, may produce sensible results even when relying on crosssectional data, although all of the estimates provided here certainly deserve greater scrutiny. Better accounting for taxes, household incomes, and expenditures may also help to improve research on QOL and local labor markets in future research.

\section{References}

Aizcorbe, Ana M., Arthur B. Kennickell, and Kevin B. Moore (2003) "Recent Changes in U.S. Family Finances: Evidence from the 1998 and 2001 Survey of Consumer Finances." Federal Reserve Bulletin, 89, pp. 1-32.

Albouy, David (2009a), "The Unequal Geographic Burden of Federal Taxation." Journal of Political Economy 117(4), pp. 635-667. 
Albouy, David (2009b), "What are Cities Worth? Land Rents, Local Productivity, and the Value of Amenities." National Bureau of Economic Research Working Paper No. 14981, Cambridge, MA. Ameniya, Takeshi (1978), "A Note on a Random Coefficient Model." International Economics Review, 19, pp. 793-796.

Barro, Robert (1974) "Are Government Bonds Net Wealth?" Journal of Political Economy, 82, pp. 1095-1117.

Baum-Snow, Nathaniel and Ronni Pavan (2010) "Understanding the City Size Wage Gap" mimeo. Brown University.

Beaudry, Paul, Mark Doms, and Ethan Lewis (forthcoming) "Should the PC be Considered a Technological Revolution? Evidence from U.S. Metropolitan Areas." Journal of Political Economy.

Becker, Richard A., Lorraine Denby, Robert McGill, and Allan R. Wilks (1987) "Analysis of Data From the Places Rated Almanac." The American Statistician, 41, pp. 169-186.

Beeson, Patricia E. (1991) "Amenities and Regional Differences in Returns to Worker Characteristics." Journal of Urban Economics, 30, pp. 224-241.

Beeson, Patricia E. and Randall W. Eberts (1989) "Identifying Productivity and Amenity Effects in Interurban Wage Differentials." The Review of Economics and Statistics, 71, pp. 443-452.

Berger, Mark C, Glenn C. Blomquist, and Werner Waldner (1987) "A Revealed-Preference Ranking of Quality of Life for Metropolitan Areas." Social Science Quarterly, 68, pp. 761-778.

Berry, Christopher and Edward Glaeser (2005) "The Divergence of Human Capital Levels across Cities." Regional Science 84(3), pp. 407-444.

Bishop, Kelly A. (2008) "Dynamic Model of Location Choice and Hedonic Valuation." Washington University mimeo. 
Black, Dan, Natalia Kolesnikova, and Lowell Taylor (2009). "Earnings Functions When Wages and Prices Vary by Location." Journal of Labor Economics, 27, pp. 21-47.

Black, Sandra E. (1999) "Do Better Schools Matter? Parental Valuation of Elementary Education" Quarterly Journal of Economics, 114, pp. 577-599.

Blomquist, Glenn C., Mark C. Berger, and John P. Hoehn (1988) "New Estimates of Quality of Life in Urban Areas." American Economic Review, 78, pp. 89-107.

Boskin, Michael J., Laurence J. Kotlikoff, Douglas J. Puffert, and John B. Shoven (1987) "Social Security: A Financial Appraisal Across and Within Generations." National Tax Journal, 40, pp. 19-34.

Bureau of Labor Statistics (2002) "Consumer Expenditures in 2000." Washington D.C.: Government Printing Office

Burnell, James D. and George Galster (1992) "Quality-of-life Measurements and Urban Size: An Empirical Note." Urban Studies, 29, pp. 727-735.

Carlino, Gerald A. and Albert Saiz (2008) "City Beautiful." Federal Reserve Bank of Philadelphia Working Paper No. 08-22.

Carrillo, Paul E., Dirk W. Early, and Edgar O. Olsen. (2010) "A Panel of Price Indices for Housing, Other Goods, and All Goods for All Areas in the United States 1982-2008." mimeo, University of Virginia.

Chay, Kenneth and Michael Greenstone (2005) "Does Air Quality Matter? Evidence from the Housing Market." Journal of Political Economy, 113, pp. 376-424

Chen, Yu and Stuart Rosenthal (2008) "Local Amenities and Life-Cycle Migration: Do People Move for Jobs or Fun?" Journal of Urban Economics, 64, pp. 519-537.

Clark, David, James R. Kahn and Haim Ofek (1988) "City Size, Quality of Life, and the Urbanization Deflato of the GNP: 1910-1984." Southern Economic Journal, 54, pp. 701-714. 
Combes, Pierre-Philippe, Gilles Duranton and Gobillon Laurent. (2008) "Spatial Wage Disparities: Sorting Matters!" Journal of Urban Economics 63(2), pp. 723-742.

Davis, Morris and Francois Ortalo-Magne (2007) "Household Expenditures, Wages, and Rents." mimeo, University of Wisconsin.

Dinardo, John and David S. Lee (2004) "Economic Impacts of New Unionization On Private Sector Employers: 1984-2001." Quarterly Journal of Economics, 119, pp. 1383-1441.

Elgin, Duane, Tom Thomas, Tom Logothetti and Sue Cox (1974) "City Size and the Quality of Life: An Analysis of the Policy Implications of Continued Population Concentration" U.S. Department of Health, Education \& Welfare.

Epple, Dennis and Holger Sieg (1999) "Estimating Equilibrium Models of Locational Sorting." Journal of Political Economy, 107(4), pp. 645-681.

Feenberg, Daniel R. and Elisabeth Coutts (1993), "An Introduction to the TAXSIM Model." Journal of Policy Analysis and Management, 12, pp. 189-194.

Feenberg, Daniel R., Andrew W. Mitrusi, and James M. Poterba (1997), "Distributional Effects of Adopting a National Retail Sales Tax." National Bureau of Economic Research Working Paper No. 5885, Cambridge, MA.

Gabaix, Xavier (1999) "Zipf's Law for Cities: An Explanation." Quarterly Journal of Economics, 114, pp. 739-767.

Gabriel, Stuart A., Joe P. Mattey, William L. Wascher (2003) "Compensating Differentials and Evolution in the Quality-of-life among U.S. States." Regional Science and Urban Economics, 33, pp. 619-649.

Gabriel, Stuart A. and Stuart S. Rosenthal (2004) "Quality of the Business Environment versus Quality of Life: Do Firms and Households Like the Same Cities?" The Review of Economics and Statistics, 86, pp.548-444. 
Glaeser, Edward L. Joseph Gyourko and Raven E. Saks (2005) "Why Have Housing Prices Gone Up?" American Economic Review Papers and Proceedings, 95, pp. 329-333.

Glaeser, Edward L., Jed Kolko, and Albert Saiz (2001) "Consumer City." Journal of Economic Geography, 1, pp. 27-50.

Glaeser, Edward L. and David Maré (2001) "Cities and Skills." Journal of Labor Economics, 19, pp. 316-342.

Glaeser, Edward L. and Kristina Tobio (2007) "The Rise of the Sunbelt." National Bureau of Economic Research Working Paper No. 13071, Cambridge, MA.

Greenwood, Michael J., Gary L. Hunt, Dan S. Rickman, and George I. Treyz (1991) "Migration, Regional Equilibrium, and the Estimation of Compensating Differentials." American Economic Review, 81, pp. 1382-1390.

Gyourko, Joseph, Christopher Mayer, and Todd Sinai (2006) "Superstar Cities." National Bureau of Economic Research Working Paper No. 12355, Cambridge, MA.

Gyourko, Joseph and Joseph Tracy (1989) "The Importance of Local Fiscal Conditions in Analyzing Local Labor Markets." Journal of Political Economy, 97, pp. 1208-31.

Gyourko, Joseph and Joseph Tracy (1991) "The Structure of Local Public Finance and the Quality of Life." Journal of Political Economy, 99, pp. 774-806.

Gyourko, Joseph, Matthew Kahn and Joseph Tracy (1999) "Quality of Life and Environmental Comparisons." in E. Mills and P. Cheshire, eds. Handbook of Regional and Urban Economics, Vol. 3. Amsterdam: North Holland.

Heckman, James and Jose Scheinkman (1987) "The Importance of Bundling in a GormanLancaster Model of Earnings" The Review of Economic Studies, 54(2), pp. 243-255. 
Hirsch, Barry T. and David A. Macpherson (2003) "Union Membership and Coverage Database from the Current Population Survey: Note." Industrial and Labor Relations Review, 56, pp. 34954.

Hoch, Irving (1972) "Income and City Size." Urban Studies, 9, pp. 299-328.

Hoehn, John P., Mark C. Berger and Glenn C. Blomquist (1987) "A Hedonic Model of Interregional Wages, Rents, and Amenity Values." Journal of Regional Science, pp. 605-620.

Hunt, Gary L. (1993) "Equilibrium and Disequilibrium in Migration Modelling." Regional Studies, 27, pp. 341-349.

Ioannides, Yannis M. and Henry G. Overman (2003). "Zipf's Law for Cities: An Empirical Examination." Regional Science and Urban Economics, 33(2), pp. 127-137.

Katz, Lawrence F. and Kevin M. Murphy (1992) "Changes in Relative Wages, 1963-1987: Supply and Demand Factors." Quarterly Journal of Economics, 107(1), pp. 35-78.

Kennan, John and James R. Walker (2003) "The Effect of Expected Income on Individual Migration Decisions." NBER Working Paper No. 9585. Cambridge, MA.

Koo, Jahyeoung, Keith R. Phillips, and Fiona D. Sigalla (2000) "Measuring Regional Cost of Living." Journal of Business \& Economic Statistics, 18, pp. 127-136.

Krueger, Alan B. (1999), "Measuring Labor's Share." American Economic Review, 89, pp. 45-51.

Lambiri, Dionysia, Bianca Biagi, and Vicente Royuela (2007) "Quality of Life in the Economic and Urban Economic Literature." Social Indicators Research, 84, pp. 1-25.

Lee, Sanghoon (2010) "Ability Sorting and Consumer City." Journal of Urban Economics 68, pp. 20-33.

Lewis, H. G. (1986) Union Relative Wage Effects: A Survey Chicago: University of Chicago Press. 
Malpezzi, Stephen, Gregory H. Chun, and Richard K. Green (1998) "New Place-to-Place Housing Price Indexes for U.S. Metropolitan Areas, and Their Determinants." Real Estate Economics, 26, pp. 235-274.

Moretti, Enrico (2004) "Estimating the Social Return to Education: Evidence from Longitudinal and Repeated Cross-Sectional Data." Journal of Econometrics, 121, pp. 175-212.

Moretti, Enrico (2008) "Real Wage Inequality." National Bureau of Economic Research Working Paper No. 14370, Cambridge, MA.

Nordhaus, William D. and James Tobin (1972) "Is Growth Obsolete?" in Economic Research: Retrospect and Prospect, Vol. 5. Economic Growth. New York: Columbia Univ. Press (for National Bureau of Economic Research).

Notowidigdo, Matthew (2010) "The Incidence of Local Labor Demand Shocks." mimeo, University of Chicago.

Peiser, Richard B. and Lawrence B. Smith (1985) "Homeownership Returns, Tenure Choice and Inflation. American Real Estate and Urban Economics Journal, 13, pp. 343-60.

Piketty, Thomas and Emmanuel Saez (2007) "How Progressive is the U.S. Federal tax system? A Historical and International Perspective." Journal of Economic Perspectives , 21, pp. 3-24.

Quigley, John Q. and Stephen Raphael (2005) "Regulation and the High Cost of Housing in California." American Economic Review Papers and Proceedings, 95, pp. 324-328.

Rappaport, Jordan (2007) "Moving to Nicer Weather." Regional Science and Urban Economics, 37, pp. 375-398.

Rappaport, Jordan (2008) "Consumption Amenities and City Population Density." Regional Science and Urban Economics, 38, pp. 533-552.

Rappaport, Jordan and Jeffrey D. Sachs (2003) "The United States as a Coastal Nation." Journal of Economic Growth, 8, pp. 5-46. 
Roback, Jennifer (1980) "The Value of Local Urban Amenities: Theory and Measurement." Ph.D. dissertation, University of Rochester.

Roback, Jennifer (1982) "Wages, Rents, and the Quality of Life." Journal of Political Economy, 90, pp. 1257-1278.

Roback, Jennifer (1988) "Wages, Rents, and Amenities: Differences among Workers and Regions." Economic Inquiry, 26, pp. 23-41.

Ruggles, Steven; Matthew Sobek; Trent Alexander; Catherine A. Fitch; Ronald Goeken; Patricia Kelly Hall; Miriam King; and Chad Ronnander. (2004) Integrated Public Use Microdata Series: Version 3.0. Minneapolis: Minnesota Population Center.

Rosen, Harvey (1985) "Housing Subsidies: Effects on Housing Decisions, Efficien y, and Equity." in M. Feldstein and A. Auerbach, eds. Handbook of Public Economics, Vol.. 1, Amsterdam: North Holland, pp. 375-420.

Rosen, Sherwin (1979) "Wages-based Indexes of Urban Quality of Life." in P. Mieszkowski and M. Straszheim, eds. Current Issues in Urban Economics, Baltimore: John Hopkins Univ. Press.

Rosenthal, Stuart and Amanda Ross (2010) "Violent Crime, Entrepreneurship, and Cities." Journal of Urban Economics 67, pp. 135-149.

Savageau, David (1999) Places Rated Almanac. Foster City, CA: IDG Books Worldwide.

Shapiro, Jesse M. (2006) "Smart Cities: Quality of Life, Productivity, and the Growth Effects of Human Capital." The Review of Economics and Statistics, 88, pp. 324-335.

Sinha, Paramita and Maureen Cropper (2009) "The Value of Climate Amenities: Evidence from U.S. Migration Decisions." mimeo, University of Maryland.

Taylor, Paul, Rich Morin, Kim Parker, D’Vera Cohn, Wendy Wang (2009) "For Nearly Half of America, Grass is Greener Somewhere Else." Pew Research Center. 
Timmins, Christopher. (2007) "If You Cannot Take the Heat, Get Out of the Cerrado... Recovering the Equilibrium Amenity Cost of Nonmarginal Climate Change in Brazil." Journal of Regional Science, 47. pp. 1-25.

Wooldridge, Jeffrey M. (2003) "Cluster-Sample Methods in Applied Econometrics." American Economic Review: Papers and Proceedings, 93, pp. 133-138.

Zipf, G. (1949) Human Behaviour and the Principle of Least Effort. Reading MA: AddisonWesley. 


\section{Appendix - Not for Publication}

\section{A Additional Theoretical Details}

\section{A.1 Aggregation of Types}

To aggregate types, let labor be aggregated according to the CES aggregator in section 5.4 and for simplicity, that there are two goods: a good $x$ traded across cities, and a home good, $y$, like housing, that is not traded and has a price $p^{j}$. Production is assumed to have constant returns to scale in labor, which can differ by household, together with capital and home-goods, which can be used as inputs. In equilibrium, because firm are mobile, the unit cost function for $x$ must equal the price of $x$, which is one

$$
c_{X}\left(w_{1}^{j} / A_{1 X}^{j}, \ldots, w_{g}^{j} / A_{G X}^{j}, p^{j}\right)=1
$$

Log-linearizing (A.1) around the national average

$$
\sum_{g} \theta_{g} \hat{w}_{g}^{j}+\theta_{Y} \hat{p}^{j}=\sum_{g} \theta_{g} \hat{A}_{g}^{j} \equiv \hat{A}_{X}^{j}
$$

where $\theta_{g}$ is used to denote the cost-share of each labor type. Let the share of national income accruing to type $g$ worker be $\mu_{g}=\bar{N}_{g} \bar{m}_{g} / \sum_{g^{\prime}} \bar{N}_{g^{\prime}} \bar{m}_{g^{\prime}}$, defin the following income-weighted averages

$$
s_{y}=\sum_{g} \mu_{g} s_{y g}, \hat{Q}^{j}=\sum_{g} \mu_{g} \hat{Q}_{g}^{j},
$$

and let $s_{x}=1-s_{y}$.

A case worth considering is one where type- 1 households receive all of their income from wages, and type- 2 households receive all their income from capital and land. This approximates the situations of prime-age workers, whose incomes are fully tied to local-wage levels, and retirees, whose incomes are completely independent of local-wage levels. Thus $\mu_{1}=s_{w}=s_{x} \theta_{1}$ and $\mu^{b}=1-s_{w}=s_{y}+s_{x}\left(1-\theta_{1}\right)$. In this situation, we expect 1-types to sort into high-wage cities, and 2 -types into low-wage cities. Nevertheless, approximating around the average city where sorting effects are neutralized,

$$
\begin{aligned}
s_{y 1} \hat{p}^{j}-\left(1-\tau_{1}^{\prime}\right) \hat{w}_{1}^{j} & =\hat{Q}_{1}^{j} \\
s_{y 2} \hat{p}^{j} & =\hat{Q}_{2}^{j}
\end{aligned}
$$

Averaging these two equations according to their shares of total income, $s_{w}$ and $1-s_{w}$, produces equation (2) in the main text. This result is more approximate in cities with prices and wages far from the average, where sorting is more of an issue. A second-order approximation would require that labor income be weighed more heavily in high-wage cities.

An advantage of using income-weighted averages is that it produces sensible comparative statics results when considering the effect of differences in QOL and productivity for either householdtype on wages and home-good prices. Ignoring taxes for expositional ease, solving the system 
reveals the wage differential for a type 1 household:

$$
s_{w 1} \hat{w}_{1}^{j}=\frac{\mu_{1}}{s_{R}}\left(s_{y 1} \hat{Q}^{b}-s_{y 2} \hat{Q}^{a}\right)-\frac{s_{x} \theta_{Y}}{s_{R}} \hat{Q}_{1}^{j}+\frac{s_{y}}{s_{R}} s_{x} \hat{A}_{X}
$$

where $s_{R}=s_{y}+s_{x} \theta_{Y}$. The term beginning with $\mu_{1}$ explains how type 1 is paid less in cities with amenities it values relatively more. Both types are paid more in productive cities, $\hat{A}_{X}$, regardless of which type of labor is made more productive. The home-good and average wage differential, weighted by wage-income shares, aggregate neatly into

$$
\begin{aligned}
\hat{p}^{j} & =\frac{1}{s_{R}} \hat{Q}^{j}+\frac{s_{x}}{s_{R}} \hat{A}_{X}^{j} \\
\hat{w}^{j} & \equiv \frac{1}{s_{w}} \sum_{g} \mu_{j} s_{w g} \hat{w}_{g}^{j}=-\frac{\theta_{Y}}{\theta_{N} s_{R}} \hat{Q}^{j}+\frac{s_{y} s_{x}}{s_{R}} \hat{A}_{X}^{j}
\end{aligned}
$$

reflectin how local QOL and productivity fully determine cost and wage differences across cities.

\section{A.2 Functional Form and Aggregation over Incomes}

Assume that utility takes the following form with separable labor supply and $\sigma_{Q}$ representing the elasticity of substitution between $Q$ and the composite commodity $\phi(x, y)$, where $\phi$ is homothetic:

$$
U(x, y ; Q)=\left[\omega Q^{\frac{\sigma_{Q}-1}{\sigma_{Q}}}+\phi(x, y)^{\frac{\sigma_{Q}-1}{\sigma_{Q}}}\right]^{\frac{\sigma_{Q}}{\sigma_{Q}-1}}
$$

Then it is possible to show that

$$
p_{Q}=\frac{\partial V / \partial Q}{\partial V / \partial m}=\frac{\omega}{\lambda}\left(\frac{m \lambda}{Q}\right)^{\frac{1}{\sigma_{Q}}}
$$

where $\lambda=$ the marginal utility of consumption. In the case where quality-of-life and consumption are perfect substitutes, $\sigma_{Q} \rightarrow \infty$, then $p_{Q}=\omega / \lambda$, which is constant. If instead, preferences are Cobb-Douglas, $\sigma_{Q}=1$, then, $p_{Q}=\omega m / Q$, and $\hat{Q}=\omega \cdot d Q$. Indifference curves for the two cases 
are illustrated below

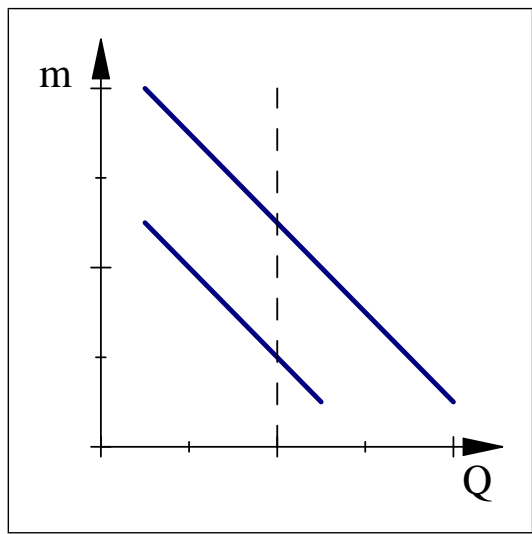

Perfect Substitutes

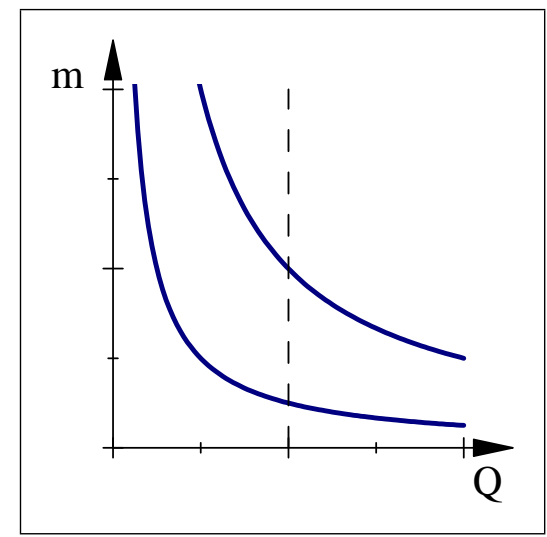

Cobb-Douglas

In the perfect substitutes case, the willingness to pay for quality-of-life remains constant with income. In the Cobb-Douglas case, the willingness to pay rises proportionally with income. It is this latter case which more consistent with the theoretical presentation and with the semi-logarithmic functional forms justifie empirically in Section B.3.

\section{A.3 Second-Order Approximation of the Mobility Condition}

The first-orde approximation of QOL in equation (2) may be expanded into a second-order approximation, which solves the quadratic equation

$\frac{1}{s_{x}+s_{y}}\left(\hat{Q}^{j}\right)^{2}-\left(\frac{s_{y}}{s_{x}+s_{y}} \hat{p}+1\right) \hat{Q}^{j}+s_{y}\left(1-\frac{1}{2} \eta^{c} \hat{p}^{j}\right) \hat{p}^{j}-\left(1-\tau^{\prime}\right) s_{w}\left[1+\frac{1}{2} \varepsilon_{\left(1-\tau^{\prime}\right)} s_{w} \hat{w}^{j}\right] \hat{w}^{j}=0$

where $\eta^{c}$ is the compensated elasticity of demand for home goods, and $\varepsilon_{\left(1-\tau^{\prime}\right)}$ is the elasticity of the marginal net of tax rate $\left(1-\tau^{\prime}\right)$ with respect to income, $m$, or

$$
\varepsilon_{\left(1-\tau^{\prime}\right)}=\frac{d \ln \left(1-\tau^{\prime}\right)}{d \ln m}=\frac{-\tau^{\prime \prime}}{1-\tau^{\prime}} m
$$

In a progressive tax system the marginal tax rate is increasing, so $\tau^{\prime \prime}>0$, implying that this elasticity should be negative. Equation (A.7) accounts for three phenomena. First, if $\sigma_{D}<1$, then the home-good expenditure share, $s_{y}$, increases with $\hat{p}^{j}$, as the demand for home goods is inelastic. Second, because of progressivity, households who move to higher-wage areas pay a higher tax rate, reducing the net-of tax rate $\left(1-\tau^{\prime}\right)$. Third, households in higher-wage areas derive a larger fraction of income from labor sources, seen in an increasing $s_{w}$.

The impact of using the second-order approximation is considered using parameter values of $\eta^{c}$ and $\varepsilon_{\left(1-\tau^{\prime}\right)}$ that lead to the largest plausible deviation from the first-orde approximation. A value of $\eta^{c}=0.5$ is close to the lower bound of plausible values from a variety of housing-demand estimates, including Rosen (1985), Goodman and Kawai (1986), Goodman (1988) Ermisch, Findlay, and Gibb (1996), Goodman (2002), and Ionnides and Zabel (2003). Estimates of $\varepsilon_{\left(1-\tau^{\prime}\right)}$ that I obtained using data from Piketty and Saez (2007) are small, with a value of $\varepsilon_{\left(1-\tau^{\prime}\right)}=-0.1$ being the furthest plausible value away from zero. 
Using these values, mobility conditions for $\hat{Q}^{j}$ levels of $0.1,0$, and -0.1 are plotted in Figure A1 using the first-orde approximation, shown by the solid lines, and the second-order, shown by the dashed lines. Overall, the firs and second-order approximations are similar. A closer look of the second-order approximation suggests that the first-orde QOL estimates may be overestimated in high-wage-high-cost areas, but only by a very small amount.

\section{A.4 Discrete Choice Modeling}

The model presented in (5.1) has very similar implications to the discrete choice model often used in structural work. For a given individual $i$ of type $k$, in city $j$, assume that the expenditure function is given by

$$
E_{g}\left(\mathbf{p}^{j}, w_{g}^{j}, \tau, u ; \underline{Q}_{g}^{j}, \xi_{i j}\right)=\tilde{E}_{g}\left(\mathbf{p}^{j}, w_{g}^{j}, \tau ; \underline{Q}_{g}^{j}\right) \exp \left(-\xi_{i}^{j}\right) \exp (u)
$$

where and $\xi_{i j}$ represents a taste parameter of person $i$ for city $j$. With this specification we can then represent indirect utility as quasilinear: $V_{i g}^{j} \equiv-\ln \tilde{E}_{g}\left(\mathbf{p}^{j}, w_{g}^{j}, \tau ; \underline{Q}_{g}^{j}\right)+\xi_{i}^{j}$. Individuals will choose the city that maximizes utiility, which assume for simplicity is known. Additionaly, assume that $\xi_{i}^{j}$ follows a double-exponentiated (Gumbel) distribution with zero mean and variance $\pi^{2} \psi_{g}^{2} / 6$. Then the probability that someone of type $g$ will occupy city $j$ is

$$
P_{g}^{j}=\operatorname{Pr}\left(V_{i g}^{j}>\max _{j^{\prime} \neq j} V_{i g}^{j^{\prime}}\right)=\frac{\exp \left[-\ln \tilde{E}_{g}\left(\mathbf{p}^{j}, w_{g}^{j}, \tau ; \underline{Q}_{g}^{j}\right) / \psi_{g}\right]}{\sum_{j^{\prime}} \exp \left[-\ln \tilde{E}_{g}\left(\mathbf{p}^{j}, w_{g}^{j}, \tau ; \underline{Q}_{g}^{j}\right) / \psi_{g}\right]}
$$

The denominator on the right-hand side may be treated as a constant, $B$, since it does vary by city, and since we are modeling a city which only contains a small portion of the total population. When the total population is $\bar{N}_{g}$, then the population of that type in city $j$ is

$$
N_{g}^{j}=\bar{N}_{g} P_{g}^{j}=\frac{1}{B} \exp \left[-\ln \tilde{E}_{g}\left(\mathbf{p}^{j}, w_{g}^{j}, \tau ; \underline{Q}_{g}^{j}\right) / \psi_{g}\right]
$$

Taking logs and rearraning

$$
\psi_{g} \ln N_{j k}+\psi_{g} \ln B=-\ln \tilde{E}_{g}\left(\mathbf{p}^{j}, w_{g}^{j}, \tau ; \underline{Q}_{g}^{j}\right)
$$

Log-linearizing this formula, treating $B$ as a constant, gives

$$
\psi_{g} \hat{N}_{g}^{j}=s_{w g}\left(1-\tau_{g}^{\prime}\right) \hat{w}_{g}^{j}-\mathbf{s}_{\mathbf{y g}} \cdot \widehat{\mathbf{p}}^{j}+\underline{\hat{Q}}_{g}^{j}
$$

which is a simple generalization of (15). The assumption of quasilinearity, which avoids the problem of modeling income effects, is fairly innocuous for marginal households, whose second option offer almost the same utility as their firs choice. This model may be amended to have $\hat{N}_{g}^{j}$ as a dynamic change, relative to a previous level, by incorporating a switching costs for moving from one city to another, as seen in Kennan and Walker (2003). 


\section{B Data and Estimation Details}

\section{B.1 Wage and Housing Cost Data}

I use United States Census data from the 2000 Integrated Public-Use Microdata Series (IPUMS), from Ruggles et al. (2004), to calculate wage and housing price differentials. The average city has 14,199 wage and 11,119 housing-price observations; the smallest city has 1093 wage and 817 housing-price observations.

The wage differentials are calculated for workers ages 25 to 55, who report working at least 30 hours a week, 26 weeks a year. The MSA assigned to a worker is determined by their place of residence, rather than their place of work. The wage differential of an MSA is found by regressing log hourly wages on individual covariates and indicators for a worker's MSA of residence, using the coefficient on these MSA indicators. The covariates consist of

- 12 indicators of educational attainment;

- a quartic in potential experience, and potential experience interacted with years of education;

- 9 indicators of industry at the one-digit level (1950 classification)

- 9 indicators of employment at the one-digit level (1950 classification)

- 4 indicators of marital status (married, divorced, widowed, separated);

- an indicator for veteran status, and veteran status interacted with age;

- 5 indicators of minority status (Black, Hispanic, Asian, Native American, and other);

- an indicator of immigrant status, years since immigration, and immigrant status interacted with black, Hispanic, Asian, and other;

- 2 indicators for English proficien y (none or poor).

All covariates are interacted with gender.

I firs run the regression using census-person weights. From the regressions a predicted wage is calculated using individual characteristics alone, controlling for MSA, to form a new weight equal to the predicted wage times the census-person weight. These new income-adjusted weights are needed since workers need to be weighted by their income share (see Appendix A.1). The new weights are then used in a second regression, which is used to calculate the city-wage differentials from the MSA indicator variables. In practice, this weighting procedure has only a small effect on the estimated wage differentials.

Housing-cost differentials are calculated using the logarithm of rents, whether they are reported gross rents or imputed rents derived from housing values. Only housing units moved into within the last 10 years are included in the sample to ensure that the price data are fairly accurate. The differential housing cost of an MSA is calculated in a manner similar to wages, except using a regression of the actual or imputed rent on a set of covariates at the unit level. The covariates for the adjusted differential are 
- 9 indicators of building size;

- 9 indicators for the number of rooms, 5 indicators for the number of bedrooms, number of rooms interacted with number of bedrooms, and the number of household members per room;

- 2 indicators for lot size;

- 7 indicators for when the building was built;

- 2 indicators for complete plumbing and kitchen facilities;

- an indicator for commercial use;

- an indicator for condominium status (owned units only).

I firs run a regression of housing values on housing characteristics and MSA indicator variables using only owner-occupied units, weighting by census-housing weights. A new value-adjusted weight is calculated by multiplying the census-housing weights by the predicted value from this firs regression using housing characteristics alone, controlling for MSA. A second regression is run using these new weights for all units, rented and owner-occupied, on the housing characteristics fully interacted with tenure, along with the MSA indicators, which are not interacted. The houseprice differentials are taken from the MSA indicator variables in this second regression. As with the wage differentials, this adjusted weighting method has only a small impact on the measured price differentials.

Differences in wages and housing-costs predicted by observable characteristics are illustrated in Appendix Figure A4.

\section{B.2 Comparing Housing Costs and Rents}

In measuring housing costs, it is sensible to use both rental and owner-occupied units, since together these capture the housing costs of residents in a city. Nevertheless, across cities the ratio of housing prices to rents can vary substantially. Figure A2 graphs the housing-cost differentials used above, which are based on both actual rents and imputed rents of owner-occupied units, against actual rents. Across most cities, rent and housing-price differences are fairly similar, and so the two measures are fairly close. In cities with housing-cost differentials above 0.2 , such as Boston, Los Angeles, New York, and San Francisco, these housing-cost differentials are significantl larger than rent differentials. Since housing prices should reflec the present value of the stream of future rents, this suggests that relative rents in these cities were expected to rise, although it is not clear whether rents were expected to rise because of improvements in QOL, improvements in the local job-market, or for other reasons.

Using only rent differentials would result in lower QOL estimates for these higher-cost cities. However, there are a number of problems with using only rent differentials. First, rent control in cities such as San Francisco and New York may artificiall depress rents. Second, homeownership rates decline significantl as price-to-rent ratios rise, which implies that the share of rental units in the sample is larger in high-price cities. Using both rental and owner-occupied units avoids the issue of having to deal with changes in the sample composition due to changes in the 
home-ownership rate. In order to avoid these problems, and to preserve comparability with QOL estimates in the existing measure, the traditional measure of housing costs is used in the analysis here.

\section{B.3 Functional Form}

Wage and housing-cost differentials are measured logarithmically, so that $\hat{Q}^{j}$ in (2) is measured as the fraction of income a household is willing to pay (or to accept if negative) to live in city $j$, rather than an in an average city. Most studies have measured QOL in dollar terms. As explained in Appendix A.2, when aggregating across households with different incomes, the choice of logarithms applies best when households value amenities proportionally to their income, rather than in stable dollar amounts regardless of income.

Empirically, the semi-logarithmic functional form in (8) and (9) is supported by work in Blomquist, Berger, and Hoehn (1988), who use maximum likelihood estimation with a Box-Cox transformation of the form $\left(w^{\gamma}-1\right) / \gamma$. They fin that a value of $\gamma=0.1$ best fit the data for wages, and $\gamma=0.2$ for housing costs, both of which are fairly close to $\gamma=0$, which corresponds to the logarithm. Similar estimates (not shown) using much larger samples from the 2000 Census, and with MSA dummy variables on the right-hand side (rather than measured amenities), result in estimates of $\gamma$ close to 0.1 for both wages and housing costs. This is not dependent on the control variables, as a similar value of $\gamma$ is estimated if predicted effects of the controls are firs subtracted from wages and prices, with the residuals then regressed on the MSA dummies. Thus, city wage and housing-cost differentials across worker and housing types are best expressed in percentage terms rather than in dollar amounts.

\section{B.4 Amenity Data}

All climate and geographic data are calculated at the public-use microdata area (PUMA) and averaged up to the metropolitan level, weighted by population. Population density is measured at the census tract level, and also population-averaged.

Heating and cooling degree days (Annual) Degree day data are used to estimate amounts of energy required to maintain comfortable indoor temperature levels. Daily values are computed from each days mean temperature $(\max +\min / 2)$. Daily heating degree days are equal to $\max \{0,65-$ meantemp $\}$ and daily cooling degree days are $\max \{0$, meantemp -65$\}$. Annual degree days are the sum of daily degree days over the year. The data here refer to averages from 1970 to 2000 (National Climactic Data Center 2008).

Sunshine Average percentage of possible. The total time that sunshine reaches the surface of the earth is expressed as the percentage of the maximum amount possible from sunrise to sunset with clear sky conditions. (National Climactic Data Center 2008).

Average slope (percent) The average slope of the land in the metropolitan area. Coded by author using GSI software.

Coastal proximity Equal to one over the distance in miles to the nearest coastline. Coded by author using GSI software. 
Violent crimes (per capita) These consist of the average of the four z-scores (standard deviations) for aggravated assaults, robbery, forcible rape, and murder (City and County Data Book 2000).

Property crimes (per capita) These consist of the average of the four z-scores (standard deviations) for aggravated burglary, larceny, motor theft, and arson (City and County Data 2000)

Air quality index (Median) An AQI value is calculated for each pollutant in an area (groundlevel ozone, particle pollution, carbon monoxide, sulfur dioxide, and nitrogen dioxide). The highest AQI value for the individual pollutants is the AQI value for that day. An AQI over 300 is considered hazardous; under 50, good; values in between correspond to moderate, unhealthy, and very unhealthy (Environmental Protection Agency, 2008).

Bars and restaurants Number of establishments classifie as eating and drinking places (NAICS 722) in County Business Patterns 2000.

Arts and Culture Index from Places Rated Almanac (Savageau 1999). Based on a ranking of cities, it ranges from 100 (New York, NY) to 0 (Houma, LA).

\section{References}

Aura, Saku and Thomas Davidoff (forthcoming) "Supply Constraints and Housing Prices." Economics Letters.

Ermisch, J.F., J. Findlay, and K. Gibb (1996) "The Price Elasticity of Housing Demand in Britain: Issues of Sample Selection." Journal of Housing Economics, 5, pp. 64-86.

Goodman, Allen C. (1988) "An Econometric Model of Housing Price, Permanent Income, Tenure Choice, and Housing Demand." Journal of Urban Economics, 23, pp. 327-353.

Goodman Allen C. (2002) "Estimating Equilibrium Housing Demand for 'Stayers.'" Journal of Urban Economics, 51, pp. 1-24.

Goodman, Allen C. and Masahiro Kawai (1986) "Functional Form, Sample Selection, and Housing Demand." Journal of Urban Economics, 20, pp. 155-167.

Ioannides, Yannis M. and Jeffrey E. Zabel (2003) "Neighborhood Effects and Housing Demand." Journal of Applied Econometrics, 18, pp. 563-584. 
TABLE 1: WAGE, HOUSING-COST, AND QUALITY-OF-LIFE DIFFERENTIALS, 2000

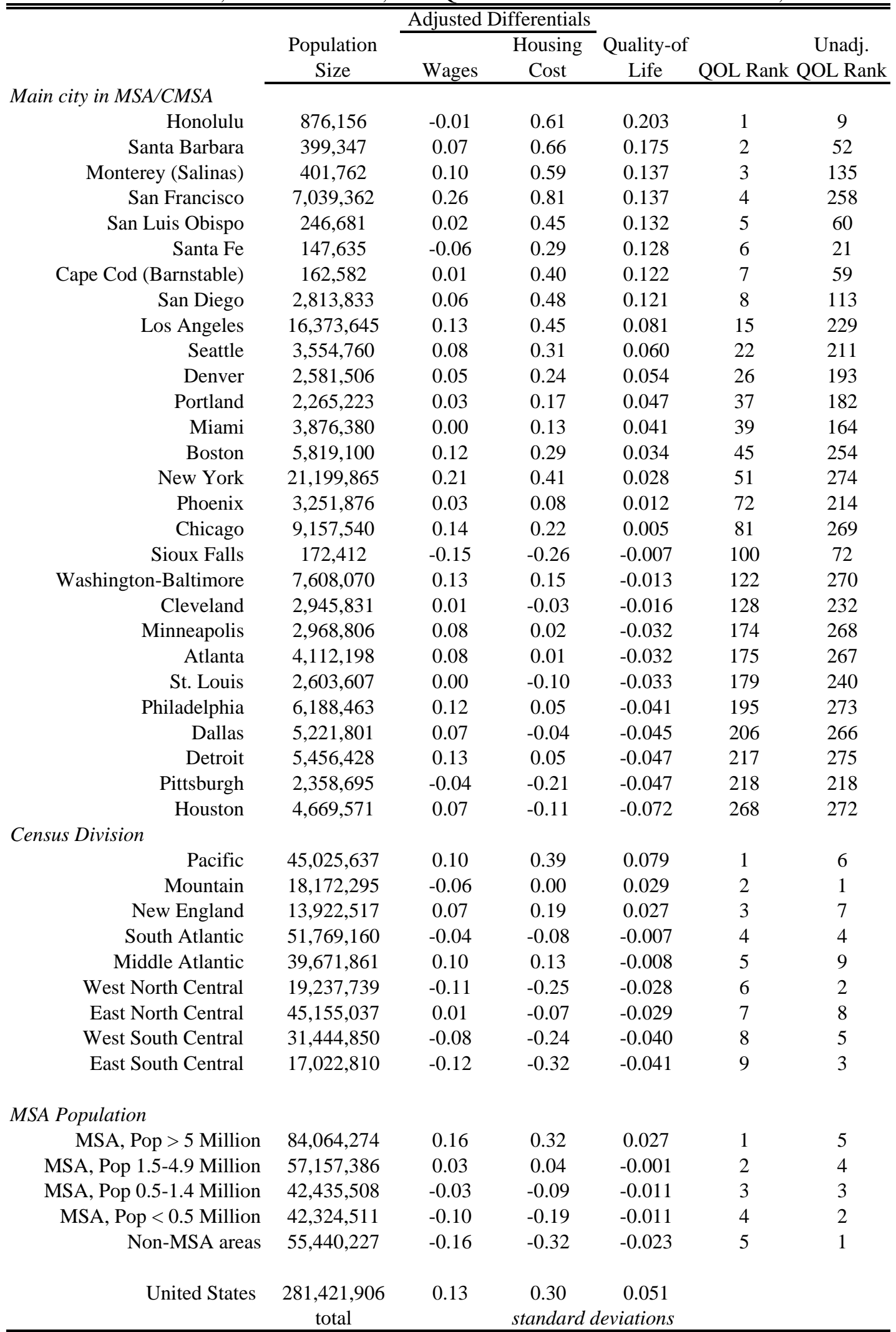

Wage and housing price data are taken from the U.S. Census 2000 IPUMS. Wage differentials are based on the average logarithm of hourly wages for full-time workers ages 25 to 55 . Housing-cost differentials based on the average logarithm of rents and housing prices for units first occupied within the last 10 years. Adjusted differentials are city-fixed effects from individual level regressions on extended sets of worker and housing covariates. 
TABLE 2: REGRESSION OF HOUSING COSTS ON WAGE LEVELS, AND A TEST OF THE CALIBRATED SLOPE COEFFECIENT FOR THE MOBILITY

\begin{tabular}{|c|c|c|c|}
\hline & $\begin{array}{l}\text { No Controls } \\
\text { (2) }\end{array}$ & $\begin{array}{c}\text { Controls for } \\
\text { Natural } \\
\text { Amenities } \\
\text { (3) }\end{array}$ & $\begin{array}{l}\text { Controls for } \\
\text { Natural and } \\
\text { Artificial } \\
\text { Amenities } \\
\text { (4) }\end{array}$ \\
\hline \multicolumn{4}{|l|}{ Panel A: Slope Estimates } \\
\hline $\begin{array}{r}\text { Wage differential } \\
\text { (robust s.e.) }\end{array}$ & $\begin{array}{c}2.14 \\
(0.20)\end{array}$ & $\begin{array}{c}1.59 \\
(0.08)\end{array}$ & $\begin{array}{c}1.48 \\
(0.10)\end{array}$ \\
\hline R-squared & 0.74 & 0.91 & 0.93 \\
\hline \multicolumn{4}{|c|}{ Panel B: p-value of test that the regression slope equals the mobility-condition slope } \\
\hline Adjusted slope $=1.53$ & 0.002 & 0.476 & 0.596 \\
\hline Unadjusted slope $=4.00$ & 0.000 & 0.000 & 0.000 \\
\hline \multicolumn{4}{|c|}{ Panel C: Implied relationship between wages and (residual) quality of life, $b_{Q}$} \\
\hline Adjusted & 0.20 & 0.02 & -0.02 \\
\hline Unadjusted & -0.62 & -0.80 & -0.83 \\
\hline \multicolumn{4}{|c|}{$\begin{array}{l}\text { Robust errors are shown in parentheses. Regressions are weighted by population. } \\
\text { Natural amenities, listed in Table } 4 \text { include heating degree days, cooling degree days, } \\
\text { percent of sunshine possible, inverse distance to a coast, and average land slope. } \\
\text { Artificial amenities include bars and restaurants per capita, Places Rated arts and } \\
\text { culture index, median air quality index, and violent and property crime per capita } \\
\text { indices. Each regression is run on } 247 \text { observations with non-missing data for all of } \\
\text { these variables. }\end{array}$} \\
\hline
\end{tabular}




\section{TABLE 3: RANK CORRELATION OF QUALITY-OF-LIFE WITH POPULAR, STATED-PREFERENCE, AND PREVIOUS HEDONIC METHODS}

\begin{tabular}{|c|c|c|}
\hline & $\begin{array}{c}\text { Adj. QOL } \\
\text { (1) }\end{array}$ & $\begin{array}{l}\text { Unadj. } \\
\text { QOL } \\
\text { (2) }\end{array}$ \\
\hline \multicolumn{3}{|c|}{ Panel A: Places Rated Almanac "Livability" Index } \\
\hline Raw Score & 0.20 & -0.29 \\
\hline Revised Score & 0.22 & -0.33 \\
\hline Number of Metro Areas & 274 & 274 \\
\hline \multicolumn{3}{|l|}{ Panel B: PEW Stated-Preference Ranking } \\
\hline "Yes" answers & 0.67 & 0.58 \\
\hline Absence of "No" answers & 0.62 & 0.60 \\
\hline Number of Metro Areas & 28 & 28 \\
\hline \multicolumn{3}{|l|}{ Panel C: Gabriel et al. (2003) State Rankings } \\
\hline Ranking from 1990 & 0.03 & 0.74 \\
\hline Ranking from 1980 & 0.09 & 0.76 \\
\hline Number of States & 50 & 50 \\
\hline \multicolumn{3}{|c|}{ Panel d: Chen and Rosenthal (2008) 2000 Rankings } \\
\hline Metro Areas Only & 0.80 & 0.81 \\
\hline Including Non-Metro Areas & 0.78 & 0.80 \\
\hline Number of Metro Areas & 241 & 241 \\
\hline Number of Non-Metro Areas & 49 & 49 \\
\hline \multicolumn{3}{|c|}{$\begin{array}{l}\text { Places rated ranking used for first city in CMSA. Revised Place } \\
\text { Rated Score eliminates cost-of-living and job-market components } \\
\text { Chen and Rosenthal estimates aggregated from the PMSA t } \\
\text { CMSA level using averages weighted by population. All rankin } \\
\text { correlations are highly significant, with p-values less than } 0.01 \text {. }\end{array}$} \\
\hline
\end{tabular}


TABLE 4: HEDONIC ESTIMATES OF THE VALUE OF INDIVIDUAL AMENITIES

\begin{tabular}{|c|c|c|c|c|c|c|}
\hline \multirow{2}{*}{$\frac{\text { Type of Amentiy Variables }}{\text { Dependent Variables }}$} & \multicolumn{4}{|c|}{$\underline{\text { Natural Amenities Only }}$} & \multicolumn{2}{|c|}{$\frac{\text { Natural and Artificial }}{\text { Amenities }}$} \\
\hline & $\begin{array}{l}\text { Adj QOL } \\
(1) \\
\end{array}$ & $\begin{array}{l}\text { Hous. Cost } \\
(2) \\
\end{array}$ & $\begin{array}{c}\text { Wages } \\
(3) \\
\end{array}$ & $\begin{array}{c}\text { Unadj. QOL } \\
(4)\end{array}$ & $\begin{array}{l}\text { Adj QOL } \\
(7) \\
\end{array}$ & $\begin{array}{c}\text { Unadj. QOL } \\
(8) \\
\end{array}$ \\
\hline $\begin{array}{r}\text { Minus 1000s of Heating Degree Days, 65F base } \\
\qquad(\text { mean }=4.37, \mathrm{sd}=2.16)\end{array}$ & $\begin{array}{l}0.0090^{* * * *} \\
(0.0021)\end{array}$ & $\begin{array}{c}0.0582 * * * \\
(0.0152)\end{array}$ & $\begin{array}{l}0.0199 * * \\
(0.0083)\end{array}$ & $\begin{array}{l}-0.0053 \\
(0.0051)\end{array}$ & $\begin{array}{l}0.0134 * * * \\
(0.0025)\end{array}$ & $\begin{array}{c}0.0076 \\
(0.0053)\end{array}$ \\
\hline $\begin{array}{r}\text { Minus 1000s of Cooling Degree Days, } 65 \mathrm{~F} \text { base } \\
\qquad(\text { mean }=1.29, \mathrm{sd}=0.89)\end{array}$ & $\begin{array}{c}0.0317 * * * \\
(0.0056)\end{array}$ & $\begin{array}{c}0.2459 * * * \\
(0.0361)\end{array}$ & $\begin{array}{l}0.0959 * * * \\
(0.0189)\end{array}$ & $\begin{array}{c}-0.0344 * * * \\
(0.0118)\end{array}$ & $\begin{array}{l}0.0325 * * * \\
(0.0050)\end{array}$ & $\begin{array}{l}-0.0066 \\
(0.0126)\end{array}$ \\
\hline $\begin{array}{r}\text { Sunshine, percent possible } \\
(\text { mean }=0.0603, \mathrm{sd}=0.078)\end{array}$ & $\begin{array}{l}0.2468 * * * \\
(0.0426)\end{array}$ & $\begin{array}{l}1.2152 * * * \\
(0.2786)\end{array}$ & $\begin{array}{l}0.3002 * * \\
(0.1490)\end{array}$ & $\begin{array}{c}0.0036 \\
(0.0924)\end{array}$ & $\begin{array}{l}0.2626 * * * \\
(0.0413)\end{array}$ & $\begin{array}{c}0.0303 \\
(0.0688)\end{array}$ \\
\hline $\begin{array}{l}\text { Inverse distance to coast } \\
(\text { mean }=60.3, \mathrm{sd}=7.8)\end{array}$ & $\begin{array}{l}0.5305^{* * *} * \\
(0.0535)\end{array}$ & $\begin{array}{l}4.0174 * * * \\
(0.4820)\end{array}$ & $\begin{array}{l}1.5426 * * * \\
(0.3016)\end{array}$ & $\begin{array}{c}-0.5383 * * * \\
(0.1926)\end{array}$ & $\begin{array}{l}0.3123 * * * \\
(0.0585)\end{array}$ & $\begin{array}{l}-0.2475 \\
(0.1696)\end{array}$ \\
\hline $\begin{array}{l}\text { Average Slope of Land, in percent } \\
\qquad(\text { mean }=1.69, \mathrm{sd}=1.65)\end{array}$ & $\begin{array}{l}0.0089 * * * \\
(0.0015)\end{array}$ & $\begin{array}{c}0.0022 \\
(0.0090)\end{array}$ & $\begin{array}{c}-0.0166 * * * \\
(0.0047)\end{array}$ & $\begin{array}{l}0.0172 * * * \\
(0.0030)\end{array}$ & $\begin{array}{c}0.0086 * * * \\
(0.0018)\end{array}$ & $\begin{array}{l}0.0102 * * * \\
(0.0032)\end{array}$ \\
\hline $\begin{array}{l}\text { Restaurants and Bars per Thousand } \\
(\text { mean }=1.71, \mathrm{sd}=0.28)\end{array}$ & & & & & $\begin{array}{c}0.0416 * * * \\
(0.0100)\end{array}$ & $\begin{array}{c}0.0805^{* * * *} \\
(0.0203)\end{array}$ \\
\hline $\begin{array}{l}\text { Log of Places Rated Arts \& Culture Index/100 } \\
\qquad(\text { mean }=0.82, \mathrm{sd}=0.24)\end{array}$ & & & & & $\begin{array}{c}0.0379 * * * \\
(0.0093)\end{array}$ & $\begin{array}{c}-0.1305 * * * \\
\quad(0.0199)\end{array}$ \\
\hline $\begin{array}{r}\text { Minus Median Air Quality Index } / 100 \\
\qquad(\text { mean }=0.50, \mathrm{sd}=0.13)\end{array}$ & & & & & $\begin{array}{c}0.0733 * * * \\
(0.0191)\end{array}$ & $\begin{array}{c}0.0515 \\
(0.0513)\end{array}$ \\
\hline $\begin{array}{l}\text { Safety from Violent Crime Index } \\
\qquad(\text { mean }=0.50, \mathrm{sd}=0.13)\end{array}$ & & & & & $\begin{array}{l}-0.0100 \\
(0.0079)\end{array}$ & $\begin{array}{l}-0.0026 \\
(0.0080)\end{array}$ \\
\hline $\begin{array}{l}\text { Safety Property Crime Index } \\
\quad(\text { mean }=0.50, \mathrm{sd}=0.13)\end{array}$ & & & & & $\begin{array}{c}0.0051 \\
(0.0043)\end{array}$ & $\begin{array}{l}-0.0019 \\
(0.0078)\end{array}$ \\
\hline $\begin{array}{r}\text { R-squared } \\
\text { Number of Observations }\end{array}$ & $\begin{array}{c}0.70 \\
321\end{array}$ & $\begin{array}{c}0.66 \\
321\end{array}$ & $\begin{array}{l}0.45 \\
321\end{array}$ & $\begin{array}{c}0.28 \\
321\end{array}$ & $\begin{array}{l}0.79 \\
247\end{array}$ & $\begin{array}{l}0.57 \\
247\end{array}$ \\
\hline
\end{tabular}

Robust standard errors shown in parentheses. $* \mathrm{p}<0.1, * * \mathrm{p}<0.05, * * * \mathrm{p}<0.01$. Regressions weighted by population. Variables are described in the Appendix. 


\begin{tabular}{|c|c|c|c|c|c|c|}
\hline \multirow{2}{*}{$\begin{array}{r}\text { Type of Amentiy Variables } \\
\text { Dependent Quality of Life Variable }\end{array}$} & \multicolumn{2}{|c|}{ No Controls } & \multicolumn{2}{|c|}{$\frac{\text { Natual Amenities }}{\underline{\text { Controls }}}$} & \multicolumn{2}{|c|}{$\frac{\text { Natural and Artificial }}{\underline{\text { Amenities }}}$} \\
\hline & $\begin{array}{l}\text { Adjusted } \\
\text { (1) }\end{array}$ & $\begin{array}{l}\text { Unadj. } \\
\text { (2) }\end{array}$ & $\begin{array}{l}\text { Adjusted } \\
\text { (3) }\end{array}$ & $\begin{array}{l}\text { Unadj. } \\
\text { (4) }\end{array}$ & $\begin{array}{l}\text { Adjusted } \\
\text { (6) }\end{array}$ & $\begin{array}{l}\text { Unadj. } \\
\text { (7) }\end{array}$ \\
\hline $\begin{array}{r}\text { Panel A: Metropolitan Population } \\
\text { Logarithm of Population }\end{array}$ & $\begin{array}{c}0.012 * * * \\
(0.004)\end{array}$ & $\begin{array}{c}-0.032 * * * \\
(0.005)\end{array}$ & $\begin{array}{c}0.002 \\
(0.002)\end{array}$ & $\begin{array}{c}-0.036 * * * \\
(0.003)\end{array}$ & $\begin{array}{c}0.003 \\
(0.003)\end{array}$ & $\begin{array}{c}-0.041 * * * \\
(0.005)\end{array}$ \\
\hline Number of Observations & 276 & 276 & 274 & 274 & 247 & 247 \\
\hline \multicolumn{7}{|l|}{ Panel B: Population Density } \\
\hline Logarithm of Density & $\begin{array}{c}0.019 * * * \\
(0.005)\end{array}$ & $\begin{array}{c}-0.046 * * * \\
(0.003)\end{array}$ & $\begin{array}{c}0.005^{* *} \\
(0.002)\end{array}$ & $\begin{array}{c}-0.054 * * * \\
(0.004)\end{array}$ & $\begin{array}{l}0.007 * \\
(0.004)\end{array}$ & $\begin{array}{c}-0.041 * * * \\
(0.008)\end{array}$ \\
\hline Number of Observations & 321 & 321 & 321 & 321 & 247 & 247 \\
\hline
\end{tabular}

Robust standard errors shown in parentheses. $* \mathrm{p}<0.1,{ }^{* *} \mathrm{p}<0.05,{ }^{* * *} \mathrm{p}<0.01$. The density measure is calculated at the census tract level, and averaged according to population. Regressions weighted by population. 
TABLE 6: ALTERNATE QUALITY-OF-LIFE INDICATORS RELATED TO QUANTITIES AND INDIVIDUAL AMENITIES

\begin{tabular}{|c|c|c|c|c|}
\hline Dependent Variables & $\begin{array}{c}\log \\
\text { Population } \\
\text { (1) }\end{array}$ & $\begin{array}{l}\log \\
\text { Density } \\
\text { (2) }\end{array}$ & $\begin{array}{c}\text { Log Pop } \\
\text { Growth } \\
1980-2000 \\
\text { (3) }\end{array}$ & $\begin{array}{l}\text { Growth- } \\
\text { Amended } \\
\text { QOL } \\
\text { Measure } \\
\text { (4) }\end{array}$ \\
\hline $\begin{array}{r}\text { Minus 1000s of Heating Degree Days, } 65 \mathrm{~F} \text { base } \\
(\text { mean }=4.37, \mathrm{sd}=2.16)\end{array}$ & $\begin{array}{c}0.0398 \\
(0.0599)\end{array}$ & $\begin{array}{l}-0.0324 \\
(0.0461)\end{array}$ & $\begin{array}{c}0.0184 \\
(0.0154)\end{array}$ & $\begin{array}{c}0.0152 * * * \\
(0.0029)\end{array}$ \\
\hline $\begin{array}{r}\text { Minus 1000s of Cooling Degree Days, 65F base } \\
\qquad(\text { mean }=1.29, \mathrm{sd}=0.89)\end{array}$ & $\begin{array}{c}0.1316 \\
(0.1100)\end{array}$ & $\begin{array}{l}-0.0726 \\
(0.1451)\end{array}$ & $\begin{array}{c}-0.0863 * * \\
(0.0353)\end{array}$ & $\begin{array}{c}0.0239 * * * \\
(0.0050)\end{array}$ \\
\hline $\begin{array}{r}\text { Sunshine, percent possible } \\
(\text { mean }=0.0603, \mathrm{sd}=0.078)\end{array}$ & $\begin{array}{c}0.7976 \\
(0.7338)\end{array}$ & $\begin{array}{l}1.6780 * * \\
(0.7537)\end{array}$ & $\begin{array}{r}0.7871^{* *} \\
(0.3081)\end{array}$ & $\begin{array}{c}0.3418 * * * \\
(0.0597)\end{array}$ \\
\hline $\begin{array}{l}\text { Inverse distance to coast } \\
(\text { mean }=60.3, \mathrm{sd}=7.8)\end{array}$ & $\begin{array}{l}9.4781 * * * \\
(2.8825)\end{array}$ & $\begin{array}{l}5.0610 * * * \\
(1.4963)\end{array}$ & $\begin{array}{c}-0.9095^{* *} \\
(0.3621)\end{array}$ & $\begin{array}{c}0.2196 * * * \\
(0.0730)\end{array}$ \\
\hline $\begin{array}{l}\text { Average Slope of Land, in percent } \\
\qquad(\text { mean }=1.69, \mathrm{sd}=1.65)\end{array}$ & $\begin{array}{l}-0.0250 \\
(0.0389)\end{array}$ & $\begin{array}{c}0.0127 \\
(0.0199)\end{array}$ & $\begin{array}{l}0.0273 * \\
(0.0139)\end{array}$ & $\begin{array}{c}0.0113 * * * \\
(0.0025)\end{array}$ \\
\hline $\begin{array}{r}\text { Restaurants and Bars per Thousand } \\
(\text { mean }=1.71, \mathrm{sd}=0.28)\end{array}$ & $\begin{array}{c}-0.8858 * * * \\
(0.309)\end{array}$ & $\begin{array}{l}-0.212 \\
(0.176)\end{array}$ & $\begin{array}{l}-0.056 \\
(0.075)\end{array}$ & $\begin{array}{c}0.0355 * * * \\
(0.012)\end{array}$ \\
\hline $\begin{array}{l}\text { Log of Places Rated Arts \& Culture Index/100 } \\
\qquad(\text { mean }=0.82, \text { sd }=0.24)\end{array}$ & $\begin{array}{l}3.7292 * * * \\
(0.228)\end{array}$ & $\begin{array}{l}0.8015^{* * *} \\
(0.159)\end{array}$ & $\begin{array}{l}0.1814 * * * \\
(0.050)\end{array}$ & $\begin{array}{c}0.0574 * * * \\
(0.011)\end{array}$ \\
\hline $\begin{array}{r}\text { Minus Median Air Quality Index/100 } \\
(\text { mean }=0.50, \mathrm{sd}=0.13)\end{array}$ & $\begin{array}{l}-2.1739 * * * \\
(0.443)\end{array}$ & $\begin{array}{l}-0.274 \\
(0.343)\end{array}$ & $\begin{array}{l}0.2117^{*} \\
(0.122)\end{array}$ & $\begin{array}{c}0.0945^{* * * *} \\
(0.024)\end{array}$ \\
\hline $\begin{array}{l}\text { Safety from Violent Crime Index } \\
(\text { mean }=0.50, \mathrm{sd}=0.13)\end{array}$ & $\begin{array}{c}-0.1939^{*} \\
(0.114)\end{array}$ & $\begin{array}{c}0.080 \\
(0.086)\end{array}$ & $\begin{array}{c}0.0493 * \\
(0.030)\end{array}$ & $\begin{array}{l}-0.005 \\
(0.010)\end{array}$ \\
\hline $\begin{array}{l}\text { Safety Property Crime Index } \\
\quad(\text { mean }=0.50, \mathrm{sd}=0.13)\end{array}$ & $\begin{array}{l}0.3035^{* *} \\
(0.118)\end{array}$ & $\begin{array}{l}-0.103 \\
(0.074)\end{array}$ & $\begin{array}{l}-0.030 \\
(0.029)\end{array}$ & $\begin{array}{c}0.002 \\
(0.006)\end{array}$ \\
\hline $\begin{array}{r}\text { R-squared } \\
\text { Number of Observations }\end{array}$ & $\begin{array}{l}0.84 \\
247\end{array}$ & $\begin{array}{l}0.31 \\
247\end{array}$ & $\begin{array}{l}0.58 \\
247\end{array}$ & $\begin{array}{l}0.74 \\
247\end{array}$ \\
\hline
\end{tabular}

Robust standard errors shown in parentheses. ${ }^{*} \mathrm{p}<0.1, * * \mathrm{p}<0.05, * * * \mathrm{p}<0.01$. Regressions weighted by population. The results are in column 4 are based on the QOL measure used in column 6 of Table 4, but adding 0.1 times the log population growth, used in column 3 here. 
TABLE 7: RELATIVE WILLINGNESS TO PAY OF COLLEGE VS. HIGH-SCHOOL HEADED HOUSEHOLDS FOR WAGES, COSTS-OF-LIVING, AND AMENITIES

\begin{tabular}{|c|c|c|c|c|}
\hline \multirow[t]{2}{*}{ Dependent Variable } & \multicolumn{2}{|c|}{$\begin{array}{c}\text { College-HS } \\
\text { QOL Diff } \\
\text { Wage } \\
\text { Only }\end{array}$} & \multirow[t]{2}{*}{$\begin{array}{l}\text { College-HS } \\
\text { Relative } \\
\text { Quanity } \\
\text { Supply } \\
\text { (3) } \\
\end{array}$} & \multirow[t]{2}{*}{$\begin{array}{c}\text { College-HS } \\
\text { QOL Diff } \\
\text { Wage and } \\
\text { Together } \\
(4)\end{array}$} \\
\hline & $(1)$ & $(2)$ & & \\
\hline Overall Wage Differential & $\begin{array}{c}-0.1084 * * * \\
(0.0358)\end{array}$ & $\begin{array}{c}-0.0990 * * \\
(0.0450)\end{array}$ & $\begin{array}{l}-0.4394 \\
(0.4157)\end{array}$ & $\begin{array}{c}-0.1398 * * \\
(0.0540)\end{array}$ \\
\hline Housing-Cost Differential & $\begin{array}{c}0.0262 \\
(0.0161)\end{array}$ & $\begin{array}{l}0.0586^{* *} \\
(0.0238)\end{array}$ & $\begin{array}{l}0.7922 * * * \\
(0.1943)\end{array}$ & $\begin{array}{l}0.1321 * * * \\
(0.0300)\end{array}$ \\
\hline Log Relative Supply of College/HS Workers & & $\begin{array}{l}-0.0073 \\
(0.0071)\end{array}$ & & $\begin{array}{l}-0.1000 \\
\text { (imposed) }\end{array}$ \\
\hline $\begin{array}{l}\text { Minus 1000s of Heating Degree Days, 65F base } \\
\qquad(\text { mean }=4.37, \mathrm{sd}=2.16)\end{array}$ & & $\begin{array}{c}-0.0073 * * * \\
(0.0017)\end{array}$ & $\begin{array}{l}-0.0296 \\
(0.0216)\end{array}$ & $\begin{array}{c}-0.0101 * * * \\
(0.0025)\end{array}$ \\
\hline $\begin{array}{r}\text { Minus 1000s of Cooling Degree Days, 65F base } \\
\qquad(\text { mean }=1.29, \mathrm{sd}=0.89)\end{array}$ & & $\begin{array}{c}0.0019 \\
(0.0047)\end{array}$ & $\begin{array}{l}-0.0504 \\
(0.0548)\end{array}$ & $\begin{array}{l}-0.0028 \\
(0.0069)\end{array}$ \\
\hline $\begin{array}{r}\text { Sunshine, percent possible } \\
(\text { mean }=0.0603, \mathrm{sd}=0.078)\end{array}$ & & $\begin{array}{c}0.0150 \\
(0.0398)\end{array}$ & $\begin{array}{l}-0.4300 \\
(0.2938)\end{array}$ & $\begin{array}{l}-0.0250 \\
(0.0462)\end{array}$ \\
\hline $\begin{array}{l}\text { Inverse distance to coast } \\
(\text { mean }=60.3, \mathrm{sd}=7.8)\end{array}$ & & $\begin{array}{l}-0.1333 * * \\
(0.0561)\end{array}$ & $\begin{array}{c}-1.0452 * * \\
(0.4557)\end{array}$ & $\begin{array}{c}-0.2302 * * * \\
\quad(0.0733)\end{array}$ \\
\hline $\begin{array}{l}\text { Average Slope of Land, in percent } \\
\qquad(\text { mean }=1.69, \mathrm{sd}=1.65)\end{array}$ & & $\begin{array}{c}0.0000 \\
(0.0018)\end{array}$ & $\begin{array}{l}-0.0200 \\
(0.0143)\end{array}$ & $\begin{array}{l}-0.0020 \\
(0.0020)\end{array}$ \\
\hline $\begin{array}{r}\text { Restaurants and Bars per Thousand } \\
\qquad(\text { mean }=1.71, \mathrm{sd}=0.28)\end{array}$ & & $\begin{array}{c}0.008 \\
(0.010)\end{array}$ & $\begin{array}{c}0.100 \\
(0.115)\end{array}$ & $\begin{array}{c}0.0170 \\
(0.0155)\end{array}$ \\
\hline $\begin{array}{l}\text { Log of Places Rated Arts \& Culture Index/100 } \\
\qquad(\text { mean }=0.82, \mathrm{sd}=0.24)\end{array}$ & & $\begin{array}{l}-0.007 \\
(0.009)\end{array}$ & $\begin{array}{l}0.5982 * * * \\
(0.084)\end{array}$ & $\begin{array}{c}0.0484 * * * \\
(0.0114)\end{array}$ \\
\hline $\begin{array}{l}\text { Minus Median Air Quality Index/100 } \\
\qquad(\text { mean }=0.50, \mathrm{sd}=0.13)\end{array}$ & & $\begin{array}{c}0.024 \\
(0.017)\end{array}$ & $\begin{array}{l}0.5627 * * * \\
(0.213)\end{array}$ & $\begin{array}{c}0.0766 * * * \\
(0.0219)\end{array}$ \\
\hline $\begin{array}{l}\text { Safety from Violent Crime Index } \\
\qquad(\text { mean }=0.50, \mathrm{sd}=0.13)\end{array}$ & & $\begin{array}{c}0.000 \\
(0.004)\end{array}$ & $\begin{array}{c}0.001 \\
(0.032)\end{array}$ & $\begin{array}{c}0.0002 \\
(0.0050)\end{array}$ \\
\hline $\begin{array}{r}\text { Safety Property Crime Index } \\
(\text { mean }=0.50, \mathrm{sd}=0.13)\end{array}$ & & $\begin{array}{c}-0.0098 * * * \\
(0.003)\end{array}$ & $\begin{array}{l}-0.009 \\
(0.032)\end{array}$ & $\begin{array}{c}-0.0106 * * \\
(0.0042)\end{array}$ \\
\hline $\begin{array}{r}\text { R-squared } \\
\text { Number of Observations }\end{array}$ & $\begin{array}{l}0.10 \\
325\end{array}$ & $\begin{array}{l}0.50 \\
247\end{array}$ & $\begin{array}{l}0.67 \\
247\end{array}$ & $\begin{array}{l}0.65 \\
247\end{array}$ \\
\hline
\end{tabular}

Robust standard errors shown in parentheses. $* \mathrm{p}<0.1, * * \mathrm{p}<0.05, * * * \mathrm{p}<0.01$. Regressions weighted by population. The dependent variable in columns 1 and 2 is 0.51 times the difference between the highschool premium and college premium for a metro area, measuring the wage sacrifice of college relative to high-school workers, using average marginal tax rates and labor income shares. The dependent variable in column 3 is a Katz-Murphy (1992) measure of the supply of college relative to high-school labor. The dependent variable in column 4 is the dependent variable in column 2 plus 0.1 times the dependent variable in column 3 . 


\section{Figure 1: Housing Costs versus Wage Levels across Metro Areas, 2000}

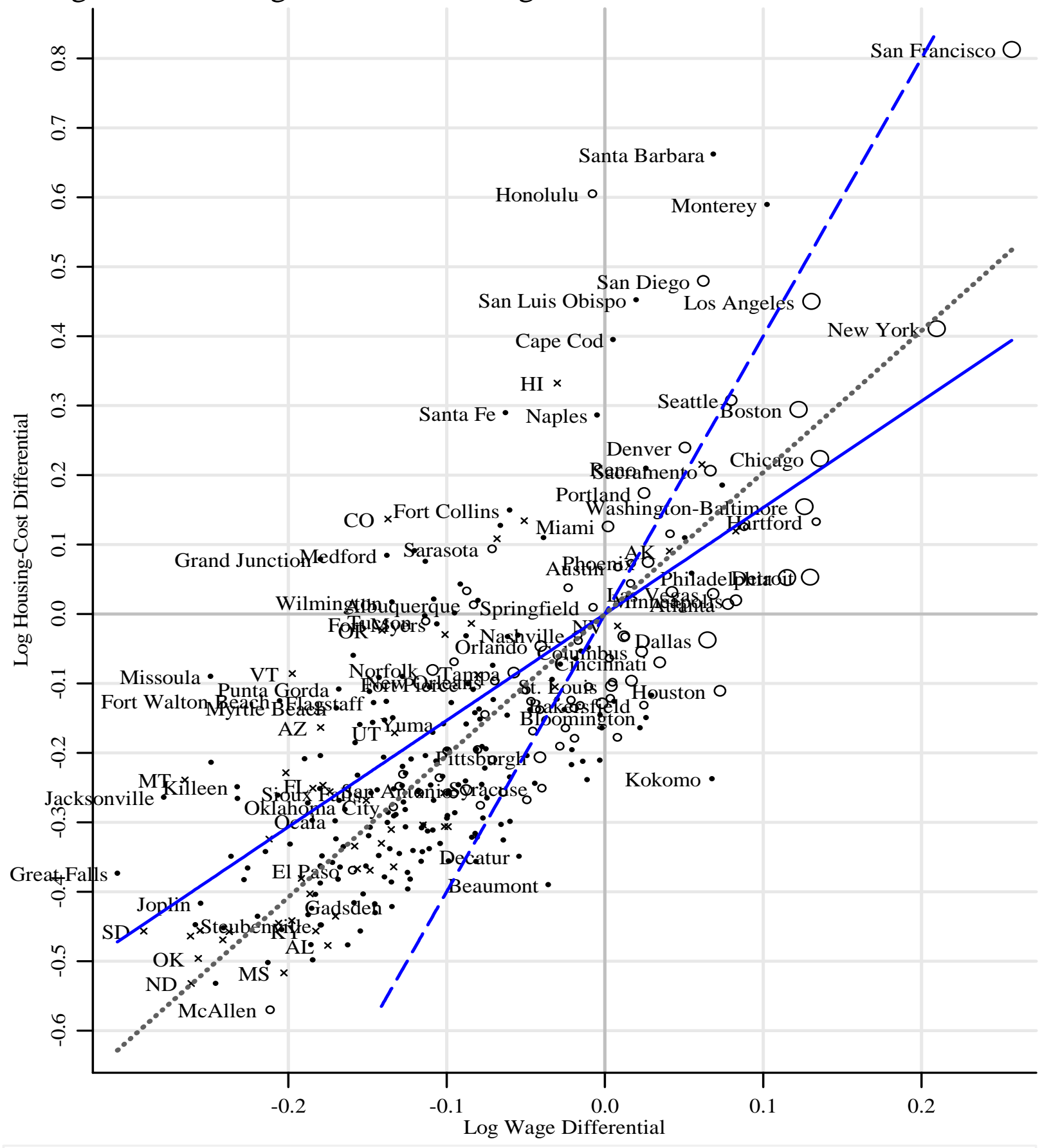
METRO POP
$\bigcirc>5.0$ Million
Avg Mobility Cond: slope $=1.53$
O 1.5-5.0 Million
○ $\quad 0.5-1.5$ Million
$-\_--$Unadjusted Avg Mobility Cond: slope $=4$
- $\quad<0.5$ Million
$\times \quad$ Non-Metro Areas
Regression Line: slope $=2.04$ (s.e. .06) 


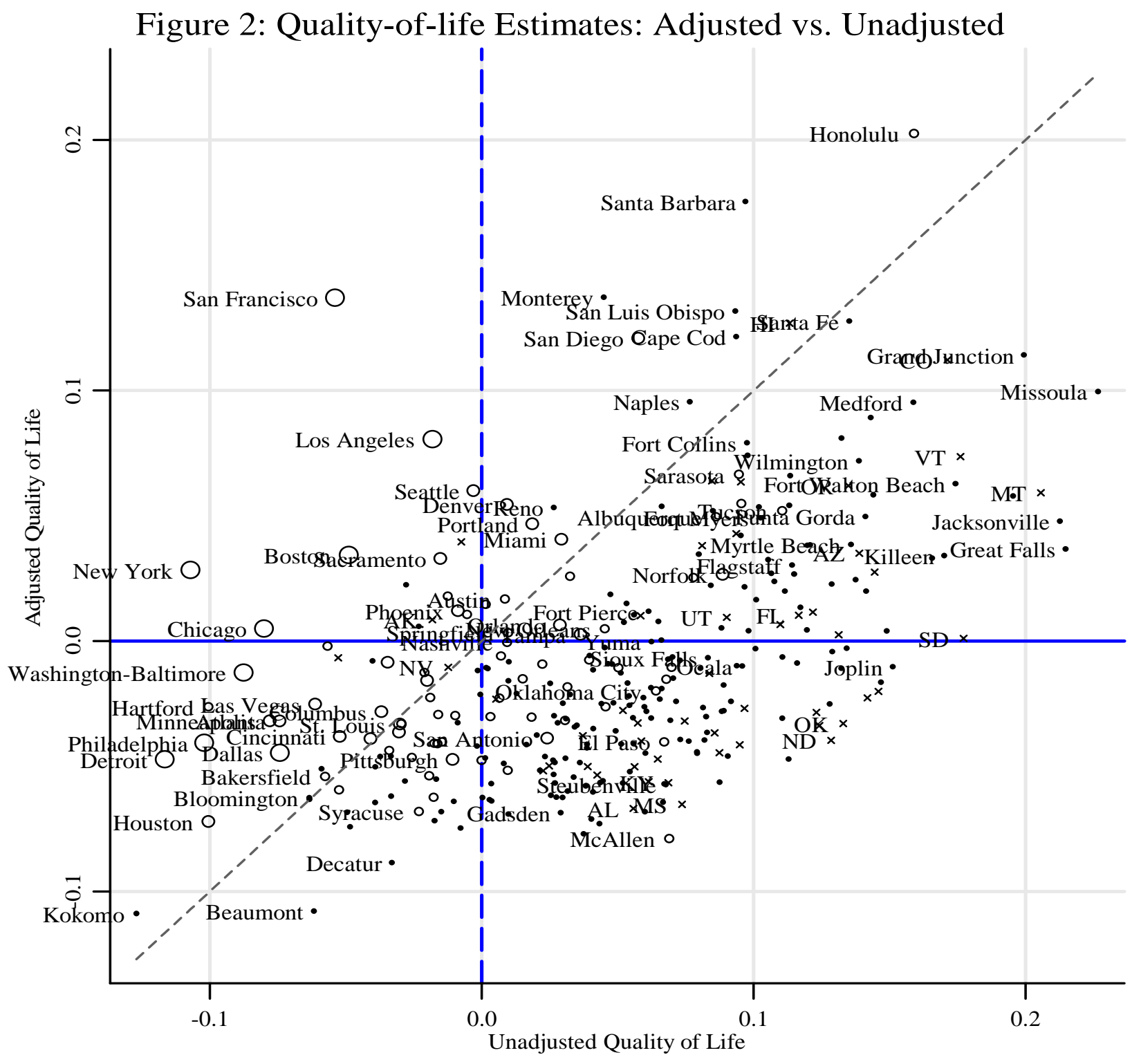

$--------\quad$ Diagonal line

Correlation between adjusted and unadjusted estimates $=.48$ (unweighted), .06 (weighted) 
Figure 3: Quality of Life and Population Growth

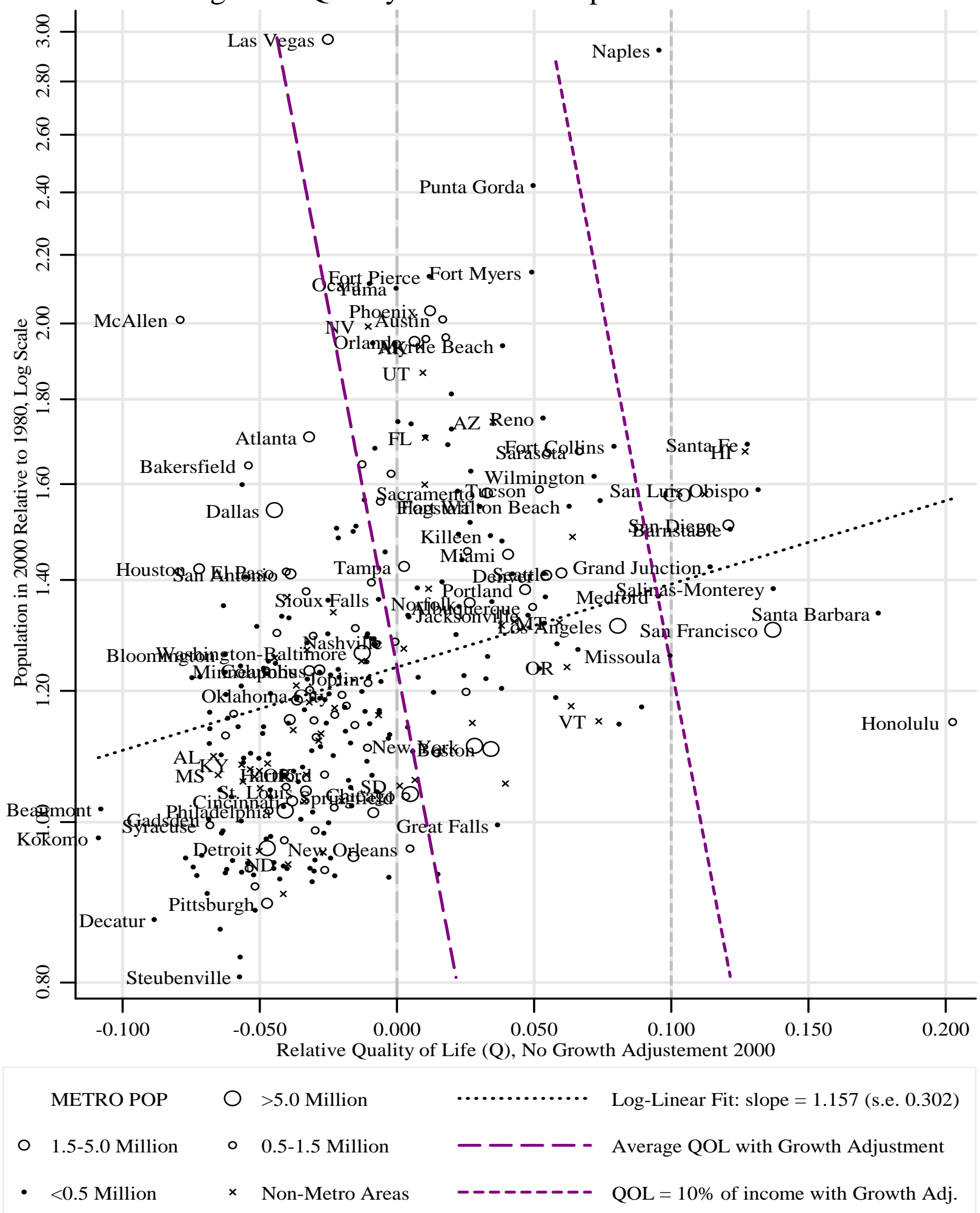




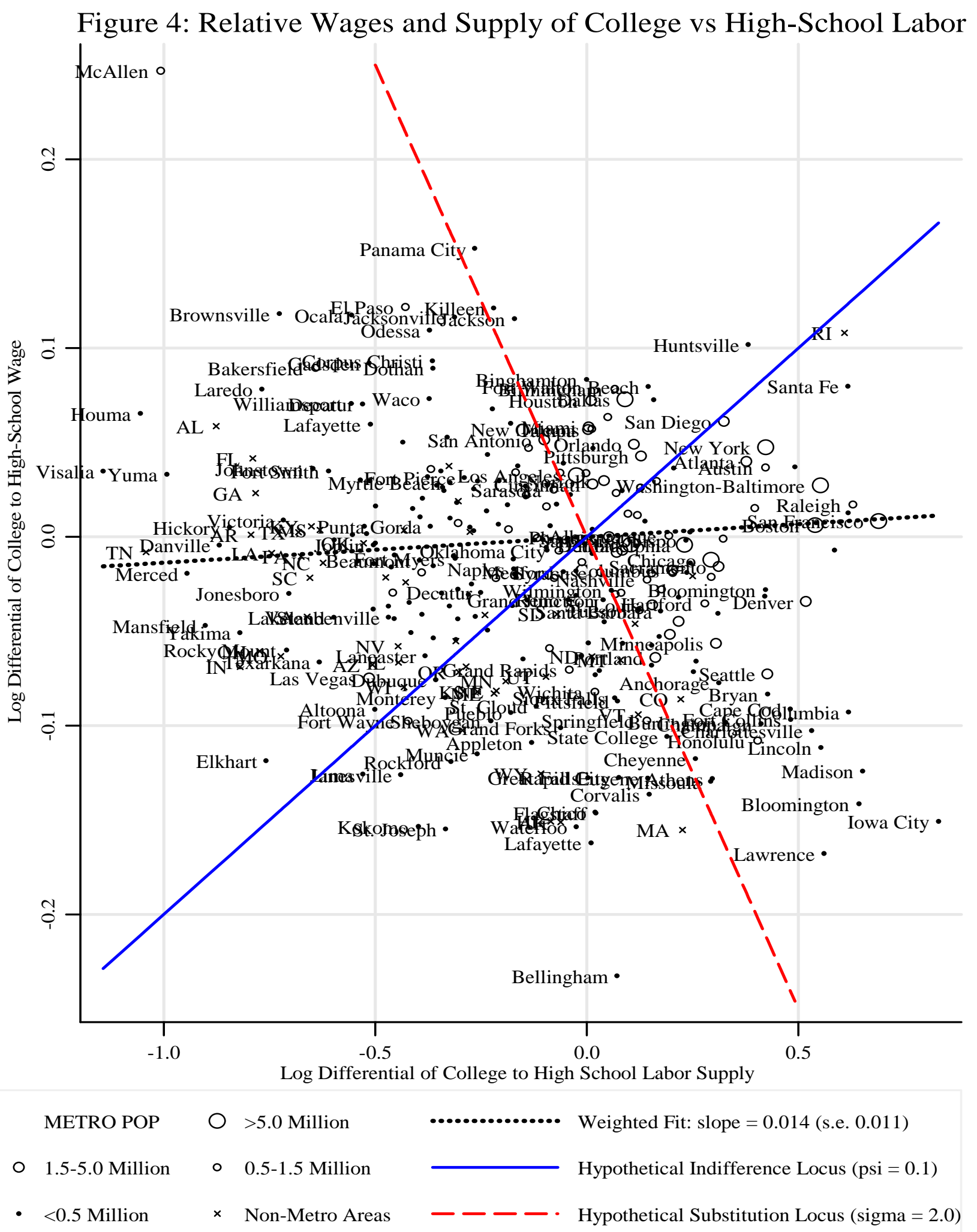




\begin{tabular}{|c|c|c|c|c|c|c|c|}
\hline \multirow[b]{2}{*}{ Full Name of Metropolitan Area } & \multirow[b]{2}{*}{$\begin{array}{c}\text { Population } \\
\text { Size }\end{array}$} & \multirow[b]{2}{*}{ Wages } & \multirow[b]{2}{*}{$\begin{array}{c}\text { Housing } \\
\text { Cost }\end{array}$} & \multicolumn{2}{|c|}{ Adjusted } & \multicolumn{2}{|c|}{ Unadjusted } \\
\hline & & & & $\begin{array}{l}\text { Quality of } \\
\text { Life }\end{array}$ & $\begin{array}{l}\text { QOL } \\
\text { Rank }\end{array}$ & $\begin{array}{l}\text { Quality of } \\
\text { Life }\end{array}$ & $\begin{array}{l}\text { QOL } \\
\text { Rank }\end{array}$ \\
\hline Honolulu, HI & 876,156 & -0.008 & 0.605 & 0.203 & 1 & 0.159 & 9 \\
\hline Santa Barbara-Santa Maria-Lompoc, CA & 399,347 & 0.069 & 0.662 & 0.175 & 2 & 0.097 & 52 \\
\hline Salinas (Monterey-Carmel), CA & 401,762 & 0.102 & 0.590 & 0.137 & 3 & 0.045 & 135 \\
\hline San Francisco-Oakland-San Jose, CA & $7,039,362$ & 0.257 & 0.813 & 0.137 & 4 & -0.054 & 258 \\
\hline San Luis Obispo-Atascadero-Paso Robles, CA & 246,681 & 0.020 & 0.452 & 0.132 & 5 & 0.093 & 60 \\
\hline Santa Fe, NM & 147,635 & -0.063 & 0.290 & 0.128 & 6 & 0.135 & 21 \\
\hline Non-metro, HI & 335,381 & -0.030 & 0.332 & 0.127 & . & 0.113 & . \\
\hline Barnstable-Yarmouth (Cape Cod), MA & 162,582 & 0.005 & 0.395 & 0.122 & 7 & 0.094 & 59 \\
\hline San Diego, CA & $2,813,833$ & 0.062 & 0.479 & 0.121 & 8 & 0.058 & 113 \\
\hline Grand Junction, CO & 116,255 & -0.180 & 0.079 & 0.114 & 9 & 0.199 & 4 \\
\hline Non-metro, $\mathrm{CO}$ & 693,605 & -0.137 & 0.137 & 0.112 & . & 0.171 & . \\
\hline Missoula, MT & 95,802 & -0.249 & -0.090 & 0.100 & 10 & 0.227 & 1 \\
\hline Naples, FL & 251,377 & -0.005 & 0.286 & 0.096 & 11 & 0.077 & 82 \\
\hline Medford-Ashland, OR & 181,269 & -0.138 & 0.084 & 0.095 & 12 & 0.159 & 10 \\
\hline Eugene-Springfield, OR & 322,959 & -0.120 & 0.091 & 0.089 & 13 & 0.143 & 15 \\
\hline Corvalis, OR & 78,153 & -0.113 & 0.076 & 0.081 & 14 & 0.132 & 23 \\
\hline Los Angeles-Riverside-Orange County, CA & $16,373,645$ & 0.131 & 0.450 & 0.081 & 15 & -0.018 & 229 \\
\hline Fort Collins-Loveland, $\mathrm{CO}$ & 251,494 & -0.060 & 0.150 & 0.079 & 16 & 0.098 & 51 \\
\hline Bellingham, WA & 166,814 & -0.066 & 0.127 & 0.074 & 17 & 0.098 & 50 \\
\hline Non-metro, VT & 439,436 & -0.198 & -0.086 & 0.074 & . & 0.176 & . \\
\hline Wilmington, NC & 233,450 & -0.134 & 0.017 & 0.072 & 18 & 0.139 & 18 \\
\hline Sarasota-Bradenton, FL & 589,959 & -0.071 & 0.094 & 0.066 & 19 & 0.095 & 57 \\
\hline Burlington, VT & 169,391 & -0.108 & 0.021 & 0.066 & 20 & 0.113 & 35 \\
\hline Non-metro, CA & $1,121,254$ & -0.051 & 0.134 & 0.064 & . & 0.085 & . \\
\hline Non-metro, MA & 247,672 & -0.068 & 0.108 & 0.063 & . & 0.095 & . \\
\hline Fort Walton Beach, FL & 170,498 & -0.205 & -0.125 & 0.063 & 21 & 0.174 & 6 \\
\hline Non-metro, OR & 919,033 & -0.141 & -0.024 & 0.062 & . & 0.135 & . \\
\hline Seattle-Tacoma-Bremerton, WA & $3,554,760$ & 0.080 & 0.308 & 0.060 & 22 & -0.003 & 211 \\
\hline Non-metro, MT & 596,684 & -0.265 & -0.239 & 0.059 & . & 0.206 & . \\
\hline Asheville, NC & 225,965 & -0.159 & -0.060 & 0.058 & 23 & 0.144 & 14 \\
\hline Cheyenne, WY & 81,607 & -0.249 & -0.214 & 0.058 & 24 & 0.195 & 5 \\
\hline Colorado Springs, CO & 516,929 & -0.087 & 0.033 & 0.055 & 25 & 0.096 & 55 \\
\hline Denver-Boulder-Greeley, CO & $2,581,506$ & 0.051 & 0.240 & 0.054 & 26 & 0.009 & 193 \\
\hline Charlottesville, VA & 159,576 & -0.114 & -0.003 & 0.054 & 27 & 0.113 & 36 \\
\hline Madison, WI & 426,526 & -0.039 & 0.110 & 0.054 & 28 & 0.066 & 99 \\
\hline Chico-Paradise, CA & 203,171 & -0.091 & 0.043 & 0.054 & 29 & 0.102 & 46 \\
\hline Reno, NV & 339,486 & 0.026 & 0.210 & 0.053 & 30 & 0.027 & 172 \\
\hline Portland, ME & 243,537 & -0.080 & 0.019 & 0.052 & 31 & 0.085 & 70 \\
\hline Tucson, AZ & 843,746 & -0.113 & -0.010 & 0.052 & 32 & 0.111 & 41 \\
\hline Punta Gorda, FL & 141,627 & -0.168 & -0.108 & 0.050 & 33 & 0.141 & 17 \\
\hline Albuquerque, NM & 712,738 & -0.083 & 0.013 & 0.050 & 34 & 0.086 & 69 \\
\hline Fort Myers-Cape Coral, FL & 440,888 & -0.106 & -0.014 & 0.049 & 35 & 0.103 & 45 \\
\hline Jacksonville, NC & 150,355 & -0.279 & -0.264 & 0.048 & 36 & 0.213 & 3 \\
\hline Portland-Salem, OR-WA & $2,265,223$ & 0.025 & 0.174 & 0.047 & 37 & 0.019 & 182 \\
\hline Non-metro, $\mathrm{NH}$ & 496,087 & -0.101 & -0.030 & 0.043 & . & 0.094 & . \\
\hline Redding, CA & 163,256 & -0.095 & 0.001 & 0.042 & 38 & 0.095 & 56 \\
\hline Miami-Fort Lauderdale, FL & $3,876,380$ & 0.002 & 0.126 & 0.041 & 39 & 0.029 & 164 \\
\hline Non-metro, RI & 61,968 & 0.061 & 0.215 & 0.040 & . & -0.008 & . \\
\hline Myrtle Beach, SC & 196,629 & -0.170 & -0.135 & 0.039 & 40 & 0.136 & 20 \\
\hline Lawrence, KS & 99,962 & -0.149 & -0.112 & 0.038 & 41 & 0.121 & 28 \\
\hline State College, PA & 135,758 & -0.143 & -0.092 & 0.038 & 42 & 0.120 & 29 \\
\hline Non-metro, WA & 994,967 & -0.084 & -0.014 & 0.038 & . & 0.081 & . \\
\hline Great Falls, MT & 80,357 & -0.308 & -0.373 & 0.037 & 43 & 0.215 & 2 \\
\hline Non-metro, AZ & 603,632 & -0.180 & -0.163 & 0.035 & . & 0.139 & . \\
\hline Iowa City, IA & 111,006 & -0.088 & -0.032 & 0.035 & 44 & 0.080 & 78 \\
\hline Boston-Worcester-Lawrence, MA-NH-ME-CT & $5,819,100$ & 0.122 & 0.294 & 0.034 & 45 & -0.049 & 254 \\
\hline Killeen-Temple, TX & 312,952 & -0.232 & -0.249 & 0.034 & 46 & 0.170 & 7 \\
\hline Rapid City, SD & 88,565 & -0.232 & -0.266 & 0.033 & 47 & 0.166 & 8 \\
\hline Sacramento-Yolo, CA & $1,796,857$ & 0.067 & 0.206 & 0.033 & 48 & -0.015 & 222 \\
\hline Bloomington, IN & 120,563 & -0.128 & -0.090 & 0.032 & 49 & 0.105 & 44 \\
\hline Flagstaff, AZ-UT & 122,366 & -0.146 & -0.128 & 0.030 & 50 & 0.114 & 34 \\
\hline New York, Northern New Jersey, Long Island, NY-NJ-CT-PA & $21,199,864$ & 0.210 & 0.411 & 0.028 & 51 & -0.107 & 274 \\
\hline Non-metro, ME & 808,317 & -0.202 & -0.229 & 0.027 & . & 0.144 & . \\
\hline Bryan-College Station, TX & 152,415 & -0.138 & -0.126 & 0.027 & 52 & 0.107 & 43 \\
\hline Panama City, FL & 148,217 & -0.155 & -0.159 & 0.027 & 53 & 0.115 & 33 \\
\hline Norfolk-Virginia Beach-Newport News, VA- & $1,569,541$ & -0.109 & -0.081 & 0.027 & 54 & 0.089 & 65 \\
\hline Salt Lake City-Ogden, UT & $1,333,914$ & -0.023 & 0.038 & 0.026 & 55 & 0.033 & 156 \\
\hline Charleston-North Charleston, SC & 549,033 & -0.095 & -0.069 & 0.025 & 56 & 0.078 & 81 \\
\hline Fayetteville, NC & 302,963 & -0.190 & -0.209 & 0.024 & 57 & 0.138 & 19 \\
\hline
\end{tabular}




\begin{tabular}{|c|c|c|c|c|c|c|c|}
\hline \multirow[b]{2}{*}{ Full Name of Metropolitan Area } & \multirow[b]{2}{*}{$\begin{array}{c}\text { Population } \\
\text { Size }\end{array}$} & \multirow[b]{2}{*}{ Wages } & \multirow[b]{2}{*}{$\begin{array}{c}\text { Housing } \\
\text { Cost }\end{array}$} & \multicolumn{2}{|c|}{ Adjusted } & \multicolumn{2}{|c|}{ Unadjusted } \\
\hline & & & & $\begin{array}{l}\text { Quality of } \\
\text { Life }\end{array}$ & $\begin{array}{l}\text { QOL } \\
\text { Rank }\end{array}$ & $\begin{array}{l}\text { Quality of } \\
\text { Life }\end{array}$ & $\begin{array}{l}\text { QOL } \\
\text { Rank } \\
\end{array}$ \\
\hline Gainesville, FL & 217,955 & -0.147 & -0.156 & 0.024 & 58 & 0.108 & 42 \\
\hline Columbia, MO & 135,454 & -0.180 & -0.204 & 0.023 & 59 & 0.129 & 26 \\
\hline Anchorage, AK & 260,283 & 0.074 & 0.185 & 0.022 & 60 & -0.028 & 237 \\
\hline Tallahassee, FL & 284,539 & -0.111 & -0.106 & 0.022 & 61 & 0.084 & 71 \\
\hline Lincoln, NE & 250,291 & -0.134 & -0.150 & 0.022 & 62 & 0.097 & 53 \\
\hline Daytona Beach, FL & 493,175 & -0.158 & -0.185 & 0.020 & 63 & 0.111 & 38 \\
\hline Las Cruces, NM & 174,682 & -0.207 & -0.261 & 0.020 & 64 & 0.141 & 16 \\
\hline Provo-Orem, UT & 368,536 & -0.055 & -0.030 & 0.019 & 65 & 0.047 & 130 \\
\hline West Palm Beach-Boca Raton, FL & $1,131,184$ & 0.041 & 0.115 & 0.018 & 66 & -0.012 & 219 \\
\hline Austin-San Marcos, TX & $1,249,763$ & 0.008 & 0.067 & 0.017 & 67 & 0.009 & 194 \\
\hline Athens, GA & 153,444 & -0.139 & -0.153 & 0.016 & 68 & 0.101 & 47 \\
\hline Pittsfield, MA & 84,699 & -0.061 & -0.033 & 0.015 & 69 & 0.053 & 121 \\
\hline Providence-Fall River-Warwick, RI-MA & $1,188,613$ & 0.017 & 0.073 & 0.015 & 70 & 0.001 & 204 \\
\hline Billings, MT & 129,352 & -0.180 & -0.252 & 0.013 & 71 & 0.117 & 31 \\
\hline Phoenix-Mesa, AZ & $3,251,876$ & 0.027 & 0.075 & 0.012 & 72 & -0.009 & 214 \\
\hline Fort Pierce-Port St. Lucie, FL & 319,426 & -0.086 & -0.100 & 0.012 & 73 & 0.061 & 107 \\
\hline Non-metro, ID & 786,043 & -0.185 & -0.251 & 0.012 & . & 0.122 & . \\
\hline Raleigh-Durham-Chapel Hill, NC & $1,187,941$ & 0.016 & 0.044 & 0.011 & 74 & -0.005 & 212 \\
\hline Boise City, ID & 432,345 & -0.083 & -0.109 & 0.010 & 75 & 0.056 & 114 \\
\hline Non-metro, FL & $1,144,881$ & -0.178 & -0.247 & 0.010 & . & 0.117 & . \\
\hline Non-metro, DE & 156,638 & -0.080 & -0.088 & 0.010 & . & 0.058 & . \\
\hline Non-metro, UT & 524,673 & -0.133 & -0.171 & 0.009 & . & 0.090 & . \\
\hline Non-metro, AK & 366,649 & 0.041 & 0.090 & 0.009 & . & -0.018 & . \\
\hline Spokane, WA & 417,939 & -0.097 & -0.128 & 0.008 & 76 & 0.065 & 102 \\
\hline Yuba City, CA & 139,149 & -0.071 & -0.074 & 0.007 & 77 & 0.052 & 122 \\
\hline Non-metro, WY & 345,642 & -0.174 & -0.256 & 0.007 & . & 0.110 & . \\
\hline Orlando, FL & $1,644,561$ & -0.040 & -0.046 & 0.006 & 78 & 0.029 & 166 \\
\hline New London-Norwich, CT-RI & 293,566 & 0.050 & 0.110 & 0.006 & 79 & -0.023 & 235 \\
\hline Fayetteville-Springdale-Rogers, AR & 311,121 & -0.140 & -0.206 & 0.005 & 80 & 0.088 & 67 \\
\hline Chicago-Gary-Kenosha, IL-IN-WI & $9,157,540$ & 0.136 & 0.224 & 0.005 & 81 & -0.080 & 269 \\
\hline New Orleans, LA & $1,337,726$ & -0.070 & -0.097 & 0.005 & 82 & 0.045 & 133 \\
\hline Springfield, MO & 325,721 & -0.188 & -0.272 & 0.004 & 83 & 0.120 & 30 \\
\hline Pensacola, FL & 412,153 & -0.156 & -0.232 & 0.004 & 84 & 0.098 & 49 \\
\hline Abilene, TX & 126,555 & -0.236 & -0.349 & 0.004 & 85 & 0.149 & 12 \\
\hline Springfield, MA & 591,932 & -0.007 & 0.009 & 0.003 & 86 & 0.010 & 190 \\
\hline Tampa-St. Petersburg-Clearwater, FL & $2,395,997$ & -0.057 & -0.084 & 0.003 & 87 & 0.036 & 150 \\
\hline Non-metro, NM & 783,991 & -0.212 & -0.324 & 0.002 & . & 0.131 & . \\
\hline Non-metro, SD & 493,867 & -0.291 & -0.457 & 0.001 & . & 0.177 & . \\
\hline Melbourne-Titusville-Palm Bay, FL & 476,230 & -0.109 & -0.171 & 0.000 & 88 & 0.066 & 100 \\
\hline Yuma, AZ & 160,026 & -0.102 & -0.158 & 0.000 & 89 & 0.062 & 104 \\
\hline Nashville, TN & $1,231,311$ & -0.017 & -0.030 & -0.001 & 90 & 0.009 & 192 \\
\hline Stockton-Lodi, CA & 563,598 & 0.088 & 0.126 & -0.002 & 91 & -0.057 & 259 \\
\hline Cedar Rapids, IA & 191,701 & -0.080 & -0.137 & -0.003 & 92 & 0.045 & 134 \\
\hline Casper, WY & 66,533 & -0.226 & -0.366 & -0.003 & 93 & 0.134 & 22 \\
\hline Pueblo, CO & 141,472 & -0.168 & -0.269 & -0.003 & 94 & 0.101 & 48 \\
\hline Clarksville-Hopkinsville, TN-KY & 207,033 & -0.214 & -0.342 & -0.004 & 95 & 0.129 & 25 \\
\hline Lafayette, IN & 182,821 & -0.071 & -0.123 & -0.006 & 96 & 0.040 & 144 \\
\hline Fresno, CA & 922,516 & -0.017 & -0.039 & -0.006 & 97 & 0.007 & 196 \\
\hline Goldsboro, NC & 113,329 & -0.185 & -0.297 & -0.006 & 98 & 0.111 & 39 \\
\hline Montgomery, AL & 333,055 & -0.122 & -0.209 & -0.006 & 99 & 0.070 & 88 \\
\hline Sioux Falls, SD & 172,412 & -0.148 & -0.258 & -0.007 & 100 & 0.083 & 72 \\
\hline Non-metro, CT & 148,665 & 0.083 & 0.119 & -0.007 & . & -0.053 & . \\
\hline Lewiston-Auburn, ME & 90,830 & -0.126 & -0.229 & -0.007 & 101 & 0.069 & 92 \\
\hline Columbia, SC & 536,691 & -0.076 & -0.145 & -0.008 & 102 & 0.040 & 145 \\
\hline Hickory-Morganton-Lenoir, NC & 341,851 & -0.128 & -0.220 & -0.008 & 103 & 0.073 & 85 \\
\hline Modesto, CA & 446,997 & 0.055 & 0.059 & -0.008 & 104 & -0.040 & 251 \\
\hline Yakima, WA & 222,581 & -0.028 & -0.072 & -0.008 & 105 & 0.010 & 187 \\
\hline Milwaukee-Racine, WI & $1,689,572$ & 0.042 & 0.032 & -0.009 & 106 & -0.035 & 246 \\
\hline Laredo, TX & 193,117 & -0.199 & -0.332 & -0.009 & 107 & 0.116 & 32 \\
\hline Champaign-Urbana, IL & 179,669 & -0.082 & -0.142 & -0.009 & 108 & 0.047 & 131 \\
\hline Dover, DE & 126,697 & -0.088 & -0.158 & -0.009 & 109 & 0.048 & 129 \\
\hline Jacksonville, FL & $1,100,491$ & -0.050 & -0.110 & -0.009 & 110 & 0.022 & 179 \\
\hline Lubbock, TX & 242,628 & -0.164 & -0.282 & -0.010 & 111 & 0.094 & 58 \\
\hline Ocala, FL & 258,916 & -0.170 & -0.298 & -0.010 & 112 & 0.096 & 54 \\
\hline Joplin, MO & 157,322 & -0.255 & -0.417 & -0.010 & 113 & 0.151 & 11 \\
\hline Knoxville, TN & 687,249 & -0.128 & -0.231 & -0.011 & 114 & 0.070 & 89 \\
\hline Non-metro, NV & 250,521 & 0.008 & -0.017 & -0.011 & . & -0.012 & . \\
\hline Lancaster, PA & 470,658 & -0.015 & -0.053 & -0.011 & 115 & 0.002 & 203 \\
\hline Little Rock-North Little Rock, AR & 583,845 & -0.100 & -0.197 & -0.011 & 116 & 0.050 & 126 \\
\hline
\end{tabular}




\begin{tabular}{|c|c|c|c|c|c|c|c|}
\hline \multirow[b]{2}{*}{ Full Name of Metropolitan Area } & \multirow[b]{2}{*}{$\begin{array}{c}\text { Population } \\
\text { Size }\end{array}$} & \multirow[b]{2}{*}{ Wages } & \multirow[b]{2}{*}{$\begin{array}{c}\text { Housing } \\
\text { Cost }\end{array}$} & \multicolumn{2}{|c|}{ Adjusted } & \multicolumn{2}{|c|}{ Unadjusted } \\
\hline & & & & $\begin{array}{l}\text { Quality of } \\
\text { Life }\end{array}$ & $\begin{array}{l}\text { QOL } \\
\text { Rank }\end{array}$ & $\begin{array}{l}\text { Quality of } \\
\text { Life }\end{array}$ & $\begin{array}{l}\text { QOL } \\
\text { Rank }\end{array}$ \\
\hline Wichita Falls, TX & 140,518 & -0.228 & -0.383 & -0.011 & 117 & 0.132 & 24 \\
\hline Amarillo, TX & 217,858 & -0.144 & -0.253 & -0.011 & 118 & 0.081 & 77 \\
\hline Green Bay, WI & 226,778 & -0.018 & -0.064 & -0.011 & 119 & 0.002 & 202 \\
\hline Savannah, GA & 293,000 & -0.079 & -0.151 & -0.012 & 120 & 0.041 & 141 \\
\hline Merced, CA & 210,554 & -0.011 & -0.048 & -0.012 & 121 & -0.001 & 209 \\
\hline Washington-Baltimore, DC-MD-VA-WV & $7,608,070$ & 0.126 & 0.154 & -0.013 & 122 & -0.088 & 270 \\
\hline Charlotte-Gastonia-Rock Hill, NC-SC & $1,499,293$ & 0.013 & -0.033 & -0.013 & 123 & -0.021 & 233 \\
\hline Tuscaloosa, AL & 164,875 & -0.100 & -0.195 & -0.013 & 124 & 0.051 & 125 \\
\hline Non-metro, NC & $2,612,257$ & -0.151 & -0.268 & -0.013 & . & 0.084 & . \\
\hline Auburn-Opelika, AL & 115,092 & -0.133 & -0.252 & -0.015 & 125 & 0.070 & 87 \\
\hline Greensboro--Winston Salem--High Point, NC & $1,251,509$ & -0.047 & -0.126 & -0.015 & 126 & 0.015 & 185 \\
\hline Mobile, AL & 540,258 & -0.130 & -0.248 & -0.015 & 127 & 0.068 & 93 \\
\hline Cleveland-Akron, $\mathrm{OH}$ & $2,945,831$ & 0.012 & -0.032 & -0.016 & 128 & -0.020 & 232 \\
\hline Visalia-Tulare-Porterville, CA & 368,021 & -0.033 & -0.094 & -0.016 & 129 & 0.010 & 189 \\
\hline Lawton, OK & 114,996 & -0.259 & -0.448 & -0.016 & 130 & 0.147 & 13 \\
\hline Roanoke, VA & 235,932 & -0.107 & -0.212 & -0.017 & 131 & 0.054 & 120 \\
\hline Sheboygan, WI & 112,646 & -0.062 & -0.146 & -0.017 & 132 & 0.025 & 176 \\
\hline Bangor, ME & 90,864 & -0.170 & -0.324 & -0.018 & 133 & 0.089 & 64 \\
\hline Omaha, NE-IA & 716,998 & -0.080 & -0.195 & -0.018 & 134 & 0.032 & 158 \\
\hline Glens Falls, NY & 124,345 & -0.113 & -0.204 & -0.019 & 135 & 0.062 & 106 \\
\hline La Crosse, WI-MN & 126,838 & -0.128 & -0.247 & -0.019 & 136 & 0.066 & 98 \\
\hline Oklahoma City, OK & $1,083,346$ & -0.134 & -0.278 & -0.020 & 137 & 0.064 & 103 \\
\hline Non-metro, NE & 811,425 & -0.262 & -0.464 & -0.020 & . & 0.146 & . \\
\hline Appleton-Oshkosh-Neenah, WI & 358,365 & -0.047 & -0.138 & -0.021 & 138 & 0.013 & 186 \\
\hline Greenville, NC & 133,798 & -0.081 & -0.195 & -0.021 & 139 & 0.033 & 155 \\
\hline Des Moines, IA & 456,022 & -0.030 & -0.123 & -0.021 & 140 & 0.000 & 208 \\
\hline Lakeland-Winter Haven, FL & 483,924 & -0.118 & -0.254 & -0.022 & 141 & 0.054 & 119 \\
\hline Waterloo-Cedar Falls, IA & 128,012 & -0.127 & -0.271 & -0.023 & 142 & 0.059 & 112 \\
\hline Allentown-Bethlehem-Easton, PA & 637,958 & 0.003 & -0.064 & -0.023 & 143 & -0.019 & 230 \\
\hline Non-metro, MO & $1,800,410$ & -0.256 & -0.456 & -0.023 & . & 0.142 & . \\
\hline Louisville, KY-IN & $1,025,598$ & -0.041 & -0.138 & -0.023 & 144 & 0.007 & 197 \\
\hline Non-metro, MD & 385,446 & -0.032 & -0.105 & -0.023 & . & 0.005 & . \\
\hline Topeka, KS & 169,871 & -0.137 & -0.286 & -0.023 & 145 & 0.066 & 101 \\
\hline Dubuque, IA & 89,143 & -0.148 & -0.307 & -0.024 & 146 & 0.072 & 86 \\
\hline San Angelo, TX & 104,010 & -0.179 & -0.348 & -0.024 & 147 & 0.092 & 61 \\
\hline Rocky Mount, NC & 143,026 & -0.110 & -0.246 & -0.025 & 148 & 0.048 & 128 \\
\hline Canton-Massillon, $\mathrm{OH}$ & 406,934 & -0.078 & -0.191 & -0.025 & 149 & 0.030 & 162 \\
\hline Tyler, TX & 174,706 & -0.103 & -0.234 & -0.025 & 150 & 0.044 & 137 \\
\hline Jonesboro, AR & 82,148 & -0.241 & -0.452 & -0.025 & 151 & 0.128 & 27 \\
\hline Las Vegas, NV-AZ & $1,563,282$ & 0.068 & 0.029 & -0.025 & 152 & -0.061 & 262 \\
\hline Eau Claire, WI & 148,337 & -0.118 & -0.256 & -0.026 & 153 & 0.054 & 118 \\
\hline Biloxi-Gulfport-Pascagoula, MS & 363,988 & -0.132 & -0.289 & -0.026 & 154 & 0.060 & 111 \\
\hline Scranton--Wilkes-Barre--Hazleton, PA & 624,776 & -0.105 & -0.236 & -0.026 & 155 & 0.046 & 132 \\
\hline Hartford, CT & $1,183,110$ & 0.134 & 0.133 & -0.026 & 156 & -0.100 & 271 \\
\hline St. Joseph, MO & 102,490 & -0.165 & -0.335 & -0.027 & 157 & 0.081 & 76 \\
\hline Non-metro, IA & $1,600,191$ & -0.192 & -0.381 & -0.027 & . & 0.097 & . \\
\hline Non-metro, WI & $1,723,367$ & -0.117 & -0.260 & -0.028 & . & 0.052 & . \\
\hline Johnson City-Kingsport-Bristol, TN-VA & 480,091 & -0.180 & -0.363 & -0.028 & 158 & 0.089 & 63 \\
\hline Hattiesburg, MS & 111,674 & -0.179 & -0.364 & -0.028 & 159 & 0.088 & 66 \\
\hline Sherman-Denison, TX & 110,595 & -0.133 & -0.291 & -0.028 & 160 & 0.061 & 108 \\
\hline Columbus, $\mathrm{OH}$ & $1,540,157$ & 0.023 & -0.054 & -0.028 & 161 & -0.037 & 247 \\
\hline Non-metro, AR & $1,352,381$ & -0.237 & -0.457 & -0.029 & . & 0.123 & . \\
\hline Harrisburg-Lebanon-Carlisle, PA & 629,401 & -0.010 & -0.105 & -0.029 & 162 & -0.016 & 223 \\
\hline Dayton-Springfield, $\mathrm{OH}$ & 950,558 & -0.021 & -0.124 & -0.030 & 163 & -0.010 & 216 \\
\hline Benton Harbor, MI & 162,453 & -0.075 & -0.194 & -0.030 & 164 & 0.027 & 171 \\
\hline Alexandria, LA & 126,337 & -0.172 & -0.358 & -0.030 & 165 & 0.083 & 74 \\
\hline Baton Rouge, LA & 602,894 & -0.045 & -0.169 & -0.030 & 166 & 0.003 & 200 \\
\hline Greenville-Spartanburg-Anderson, SC & 962,441 & -0.071 & -0.210 & -0.030 & 167 & 0.018 & 183 \\
\hline Williamsport, PA & 120,044 & -0.126 & -0.282 & -0.031 & 168 & 0.056 & 116 \\
\hline Lynchburg, VA & 214,911 & -0.137 & -0.300 & -0.031 & 169 & 0.062 & 105 \\
\hline Enid, OK & 57,813 & -0.219 & -0.435 & -0.031 & 170 & 0.111 & 40 \\
\hline Jackson, MS & 440,801 & -0.093 & -0.246 & -0.031 & 171 & 0.031 & 159 \\
\hline Sharon, PA & 120,293 & -0.149 & -0.319 & -0.032 & 172 & 0.069 & 90 \\
\hline Tulsa, OK & 803,235 & -0.096 & -0.260 & -0.032 & 173 & 0.031 & 161 \\
\hline Minneapolis-St. Paul, MN-WI & $2,968,806$ & 0.083 & 0.020 & -0.032 & 174 & -0.078 & 268 \\
\hline Non-metro, VA & $1,550,447$ & -0.158 & -0.334 & -0.032 & . & 0.075 & . \\
\hline Atlanta, GA & $4,112,198$ & 0.078 & 0.014 & -0.032 & 175 & -0.074 & 267 \\
\hline York, PA & 381,751 & -0.026 & -0.138 & -0.033 & 176 & -0.009 & 215 \\
\hline Lexington, $\mathrm{KY}$ & 479,198 & -0.088 & -0.241 & -0.033 & 177 & 0.028 & 167 \\
\hline
\end{tabular}




\begin{tabular}{|c|c|c|c|c|c|c|c|}
\hline \multirow[b]{2}{*}{ Full Name of Metropolitan Area } & \multirow[b]{2}{*}{$\begin{array}{l}\text { Population } \\
\text { Size }\end{array}$} & \multirow[b]{2}{*}{ Wages } & \multirow[b]{2}{*}{$\begin{array}{l}\text { Housing } \\
\text { Cost }\end{array}$} & \multicolumn{2}{|c|}{ Adjusted } & \multicolumn{2}{|c|}{ Unadjusted } \\
\hline & & & & $\begin{array}{l}\text { Quality of } \\
\text { Life }\end{array}$ & $\begin{array}{l}\text { QOL } \\
\text { Rank }\end{array}$ & $\begin{array}{l}\text { Quality of } \\
\text { Life }\end{array}$ & $\begin{array}{l}\text { QOL } \\
\text { Rank }\end{array}$ \\
\hline Non-metro, SC & $1,205,050$ & -0.135 & -0.311 & -0.033 & . & 0.057 &. \\
\hline Non-metro, OK & $1,352,292$ & -0.257 & -0.496 & -0.033 & . & 0.133 & . \\
\hline Richmond-Petersburg, VA & 996,512 & 0.005 & -0.098 & -0.033 & 178 & -0.030 & 239 \\
\hline St. Louis, MO-IL & $2,603,607$ & 0.004 & -0.104 & -0.033 & 179 & -0.030 & 240 \\
\hline Corpus Christi, TX & 380,783 & -0.099 & -0.255 & -0.034 & 180 & 0.035 & 152 \\
\hline Non-metro, KS & $1,167,355$ & -0.241 & -0.469 & -0.034 & . & 0.124 & . \\
\hline Chattanooga, TN-GA & 465,161 & -0.099 & -0.258 & -0.034 & 181 & 0.034 & 153 \\
\hline Erie, PA & 280,843 & -0.108 & -0.268 & -0.035 & 182 & 0.041 & 140 \\
\hline Monroe, LA & 147,250 & -0.126 & -0.307 & -0.036 & 183 & 0.049 & 127 \\
\hline Kansas City, MO-KS & $1,776,062$ & -0.002 & -0.129 & -0.036 & 184 & -0.030 & 241 \\
\hline Sumter, SC & 104,646 & -0.180 & -0.388 & -0.037 & 185 & 0.083 & 73 \\
\hline Non-metro, TN & $1,827,139$ & -0.186 & -0.403 & -0.037 & . & 0.086 & . \\
\hline Springfield, IL & 201,437 & -0.076 & -0.222 & -0.038 & 186 & 0.020 & 181 \\
\hline Non-metro, MI & $1,768,978$ & -0.102 & -0.258 & -0.038 & . & 0.037 & . \\
\hline Cincinnati-Hamilton, OH-KY-IN & $1,979,202$ & 0.035 & -0.070 & -0.038 & 187 & -0.052 & 256 \\
\hline San Antonio, TX & $1,592,383$ & -0.088 & -0.254 & -0.039 & 188 & 0.024 & 177 \\
\hline Indianapolis, IN & $1,607,486$ & 0.017 & -0.096 & -0.039 & 189 & -0.041 & 252 \\
\hline Fargo-Moorhead, ND-MN & 174,367 & -0.169 & -0.382 & -0.039 & 190 & 0.073 & 84 \\
\hline Dothan, AL & 137,916 & -0.183 & -0.404 & -0.040 & 191 & 0.082 & 75 \\
\hline Non-metro, ND & 358,234 & -0.261 & -0.532 & -0.040 & . & 0.128 & . \\
\hline Non-metro, GA & $2,519,789$ & -0.141 & -0.330 & -0.040 & . & 0.059 & . \\
\hline Cumberland, MD-WV & 102,008 & -0.167 & -0.365 & -0.040 & 192 & 0.076 & 83 \\
\hline El Paso, TX & 679,622 & -0.159 & -0.369 & -0.040 & 193 & 0.067 & 96 \\
\hline Rochester, NY & $1,098,201$ & -0.019 & -0.136 & -0.040 & 194 & -0.015 & 220 \\
\hline Philadelphia-Wilmington-Atlantic City, PA-NJ-DE-MD & $6,188,463$ & 0.115 & 0.052 & -0.041 & 195 & -0.102 & 273 \\
\hline Albany-Schenectady-Troy, NY & 875,583 & -0.016 & -0.132 & -0.041 & 196 & -0.017 & 227 \\
\hline Florence, $\mathrm{AL}$ & 142,950 & -0.143 & -0.348 & -0.041 & 197 & 0.056 & 115 \\
\hline Toledo, $\mathrm{OH}$ & 618,203 & -0.025 & -0.164 & -0.041 & 198 & -0.016 & 224 \\
\hline Owensboro, KY & 91,545 & -0.136 & -0.338 & -0.041 & 199 & 0.051 & 124 \\
\hline Shreveport-Bossier City, LA & 392,302 & -0.116 & -0.308 & -0.041 & 200 & 0.039 & 146 \\
\hline Davenport-Moline-Rock Island, IA-IL & 359,062 & -0.078 & -0.245 & -0.041 & 201 & 0.016 & 184 \\
\hline Non-metro, WV & $1,042,776$ & -0.206 & -0.445 & -0.041 & . & 0.095 & . \\
\hline Elkhart-Goshen, IN & 182,791 & -0.049 & -0.204 & -0.042 & 202 & -0.002 & 210 \\
\hline Muncie, IN & 118,769 & -0.115 & -0.304 & -0.043 & 203 & 0.039 & 147 \\
\hline Grand Rapids-Muskegon-Holland, MI & $1,088,514$ & 0.004 & -0.122 & -0.044 & 204 & -0.034 & 245 \\
\hline Fort Smith, AR-OK & 207,290 & -0.187 & -0.433 & -0.044 & 205 & 0.079 & 80 \\
\hline Non-metro, TX & $3,159,940$ & -0.198 & -0.442 & -0.045 & . & 0.087 & . \\
\hline Dallas-Fort Worth, TX & $5,221,801$ & 0.065 & -0.037 & -0.045 & 206 & -0.074 & 266 \\
\hline Altoona, PA & 129,144 & -0.151 & -0.363 & -0.045 & 207 & 0.060 & 109 \\
\hline Anniston, AL & 112,249 & -0.185 & -0.424 & -0.045 & 208 & 0.079 & 79 \\
\hline Grand Forks, ND-MN & 97,478 & -0.204 & -0.455 & -0.046 & 209 & 0.091 & 62 \\
\hline Reading, PA & 373,638 & -0.003 & -0.146 & -0.046 & 210 & -0.033 & 244 \\
\hline Lansing-East Lansing, MI & 447,728 & 0.006 & -0.126 & -0.046 & 211 & -0.037 & 248 \\
\hline Evansville-Henderson, IN-KY & 296,195 & -0.095 & -0.286 & -0.046 & 212 & 0.023 & 178 \\
\hline Birmingham, AL & 921,106 & -0.019 & -0.179 & -0.047 & 213 & -0.026 & 236 \\
\hline South Bend, IN & 265,559 & -0.060 & -0.235 & -0.047 & 214 & 0.001 & 205 \\
\hline Waco, TX & 213,517 & -0.109 & -0.311 & -0.047 & 215 & 0.031 & 160 \\
\hline Bismarck, ND & 94,719 & -0.246 & -0.532 & -0.047 & 216 & 0.113 & 37 \\
\hline Non-metro, MN & $1,456,119$ & -0.156 & -0.367 & -0.047 & . & 0.065 & . \\
\hline Detroit-Ann Arbor-Flint, MI & $5,456,428$ & 0.130 & 0.053 & -0.047 & 217 & -0.117 & 275 \\
\hline Pittsburgh, PA & $2,358,695$ & -0.041 & -0.207 & -0.047 & 218 & -0.011 & 218 \\
\hline Mansfield, $\mathrm{OH}$ & 175,818 & -0.100 & -0.294 & -0.048 & 219 & 0.026 & 174 \\
\hline Wichita, KS & 545,220 & -0.064 & -0.257 & -0.048 & 220 & 0.000 & 207 \\
\hline St. Cloud, MN & 167,392 & -0.099 & -0.290 & -0.049 & 221 & 0.027 & 170 \\
\hline Florence, SC & 125,761 & -0.121 & -0.341 & -0.049 & 222 & 0.036 & 151 \\
\hline Wausau, WI & 125,834 & -0.074 & -0.265 & -0.049 & 223 & 0.008 & 195 \\
\hline Non-metro, IN & $1,690,582$ & -0.101 & -0.306 & -0.050 & . & 0.025 & . \\
\hline Non-metro, NY & $1,503,399$ & -0.115 & -0.304 & -0.050 & . & 0.039 & . \\
\hline Non-metro, IL & $1,877,585$ & -0.148 & -0.369 & -0.050 & . & 0.056 & . \\
\hline Janesville-Beloit, WI & 152,307 & -0.002 & -0.164 & -0.050 & 224 & -0.039 & 249 \\
\hline Richland-Kennewick-Pasco, WA & 191,822 & 0.030 & -0.117 & -0.051 & 225 & -0.059 & 261 \\
\hline Charleston, WV & 251,662 & -0.104 & -0.331 & -0.052 & 226 & 0.021 & 180 \\
\hline Youngstown-Warren, $\mathrm{OH}$ & 594,746 & -0.079 & -0.276 & -0.052 & 227 & 0.010 & 191 \\
\hline Non-metro, $\mathrm{OH}$ & $2,139,364$ & -0.099 & -0.306 & -0.052 & . & 0.023 & . \\
\hline Pine Bluff, AR & 84,278 & -0.159 & -0.416 & -0.052 & 228 & 0.055 & 117 \\
\hline Houma, LA & 194,477 & -0.111 & -0.338 & -0.053 & 229 & 0.027 & 173 \\
\hline Non-metro, PA & $1,889,525$ & -0.134 & -0.364 & -0.054 & . & 0.042 & . \\
\hline Buffalo-Niagara Falls, NY & $1,170,111$ & -0.028 & -0.190 & -0.054 & 230 & -0.019 & 231 \\
\hline Bakersfield, CA & 661,645 & 0.025 & -0.132 & -0.054 & 231 & -0.058 & 260 \\
\hline
\end{tabular}




\begin{tabular}{|c|c|c|c|c|c|c|c|}
\hline \multirow[b]{2}{*}{ Full Name of Metropolitan Area } & \multirow[b]{2}{*}{$\begin{array}{c}\text { Population } \\
\text { Size }\end{array}$} & \multirow[b]{2}{*}{ Wages } & \multirow[b]{2}{*}{$\begin{array}{c}\text { Housing } \\
\text { Cost }\end{array}$} & \multicolumn{2}{|c|}{ Adjusted } & \multicolumn{2}{|c|}{ Unadjusted } \\
\hline & & & & $\begin{array}{l}\text { Quality of } \\
\text { Life }\end{array}$ & $\begin{array}{l}\text { QOL } \\
\text { Rank }\end{array}$ & $\begin{array}{l}\text { Quality of } \\
\text { Life }\end{array}$ & $\begin{array}{l}\text { QOL } \\
\text { Rank }\end{array}$ \\
\hline Binghamton, NY & 252,320 & -0.112 & -0.313 & -0.054 & 232 & 0.034 & 154 \\
\hline Columbus, GA-AL & 274,624 & -0.139 & -0.379 & -0.056 & 234 & 0.045 & 136 \\
\hline Kalamazoo-Battle Creek, MI & 452,851 & -0.021 & -0.196 & -0.056 & 235 & -0.028 & 238 \\
\hline Non-metro, LA & $1,098,766$ & -0.170 & -0.435 & -0.056 & . & 0.061 & . \\
\hline Elmira, NY & 91,070 & -0.130 & -0.345 & -0.057 & 237 & 0.044 & 138 \\
\hline Non-metro, KY & $2,068,667$ & -0.183 & -0.456 & -0.057 & . & 0.069 & . \\
\hline Lafayette, LA & 385,647 & -0.116 & -0.356 & -0.057 & 238 & 0.027 & 169 \\
\hline Danville, VA & 110,156 & -0.153 & -0.403 & -0.057 & 239 & 0.052 & 123 \\
\hline Augusta-Aiken, GA-SC & 477,441 & -0.077 & -0.294 & -0.057 & 240 & 0.004 & 199 \\
\hline Wheeling, WV-OH & 153,172 & -0.179 & -0.448 & -0.057 & 241 & 0.067 & 95 \\
\hline Steubenville-Weirton, OH-WV & 132,008 & -0.180 & -0.448 & -0.057 & 242 & 0.068 & 94 \\
\hline Longview-Marshall, TX & 208,780 & -0.135 & -0.386 & -0.058 & 243 & 0.038 & 148 \\
\hline Terre Haute, IN & 149,192 & -0.125 & -0.372 & -0.060 & 245 & 0.032 & 157 \\
\hline Sioux City, IA-NE & 124,130 & -0.145 & -0.417 & -0.060 & 246 & 0.041 & 142 \\
\hline Pocatello, ID & 75,565 & -0.125 & -0.396 & -0.062 & 247 & 0.025 & 175 \\
\hline Peoria-Pekin, IL & 347,387 & -0.021 & -0.217 & -0.062 & 248 & -0.033 & 243 \\
\hline Odessa-Midland, TX & 237,132 & -0.123 & -0.382 & -0.062 & 249 & 0.027 & 168 \\
\hline Fort Wayne, IN & 502,141 & -0.049 & -0.268 & -0.062 & 250 & -0.018 & 228 \\
\hline Utica-Rome, NY & 299,896 & -0.115 & -0.342 & -0.062 & 251 & 0.030 & 163 \\
\hline Jackson, TN & 107,377 & -0.081 & -0.322 & -0.063 & 252 & 0.000 & 206 \\
\hline Bloomington-Normal, IL & 150,433 & 0.026 & -0.149 & -0.063 & 253 & -0.063 & 265 \\
\hline Rochester, MN & 124,277 & 0.022 & -0.164 & -0.063 & 254 & -0.063 & 264 \\
\hline Albany, GA & 120,822 & -0.082 & -0.316 & -0.063 & 255 & 0.003 & 201 \\
\hline Lima, $\mathrm{OH}$ & 155,084 & -0.084 & -0.322 & -0.064 & 256 & 0.004 & 198 \\
\hline Lake Charles, LA & 183,577 & -0.066 & -0.303 & -0.064 & 257 & -0.010 & 217 \\
\hline Johnstown, PA & 232,621 & -0.186 & -0.476 & -0.064 & 258 & 0.067 & 97 \\
\hline Jackson, MI & 158,422 & -0.014 & -0.212 & -0.065 & 259 & -0.039 & 250 \\
\hline Non-metro, MS & $1,820,996$ & -0.203 & -0.517 & -0.065 & . & 0.074 & . \\
\hline Macon, GA & 322,549 & -0.060 & -0.299 & -0.068 & 261 & -0.015 & 221 \\
\hline Texarkana, TX-Texarkana, AR & 129,749 & -0.185 & -0.498 & -0.068 & 262 & 0.060 & 110 \\
\hline Rockford, IL & 371,236 & -0.003 & -0.211 & -0.068 & 263 & -0.049 & 255 \\
\hline Gadsden, AL & 103,459 & -0.134 & -0.421 & -0.069 & 264 & 0.029 & 165 \\
\hline Duluth-Superior, MN-WI & 243,815 & -0.099 & -0.356 & -0.069 & 265 & 0.010 & 188 \\
\hline Parkersburg-Marietta, WV-OH & 151,237 & -0.155 & -0.457 & -0.071 & 266 & 0.040 & 143 \\
\hline Decatur, AL & 145,867 & -0.064 & -0.326 & -0.072 & 267 & -0.017 & 226 \\
\hline Houston-Galveston-Brazoria, TX & $4,669,571$ & 0.073 & -0.111 & -0.072 & 268 & -0.100 & 272 \\
\hline Huntington-Ashland, WV-KY-OH & 315,538 & -0.162 & -0.477 & -0.073 & 269 & 0.043 & 139 \\
\hline Saginaw-Bay City-Midland, MI & 403,070 & -0.011 & -0.239 & -0.074 & 270 & -0.048 & 253 \\
\hline Victoria, TX & 84,088 & -0.081 & -0.356 & -0.075 & 271 & -0.008 & 213 \\
\hline Jamestown, NY & 139,750 & -0.145 & -0.430 & -0.077 & 272 & 0.038 & 149 \\
\hline McAllen-Edinburg-Mission, TX & 569,463 & -0.212 & -0.570 & -0.079 & 273 & 0.069 & 91 \\
\hline Decatur, IL & 114,706 & -0.054 & -0.349 & -0.088 & 274 & -0.033 & 242 \\
\hline Beaumont-Port Arthur, TX & 385,090 & -0.036 & -0.390 & -0.108 & 275 & -0.062 & 263 \\
\hline Kokomo, IN & 101,541 & 0.068 & -0.237 & -0.109 & 276 & -0.127 & 276 \\
\hline
\end{tabular}


TABLE A2: LIST OF STATES BY ESTIMATED QUALITY OF LIFE

\begin{tabular}{|c|c|c|c|c|c|c|c|c|c|}
\hline \multirow[b]{2}{*}{ State } & \multirow[b]{2}{*}{ Population } & \multirow[b]{2}{*}{ Wages } & \multirow[b]{2}{*}{$\begin{array}{c}\text { Housing } \\
\text { Cost }\end{array}$} & \multicolumn{2}{|c|}{$\underline{\text { Adjusted }}$} & \multicolumn{2}{|c|}{$\underline{\text { Unadjusted }}$} & \multicolumn{2}{|c|}{ Gabriel et al. (2003) } \\
\hline & & & & $\begin{array}{c}\text { Quality of } \\
\text { Life }\end{array}$ & $\begin{array}{l}\text { QOL } \\
\text { Rank }\end{array}$ & $\begin{array}{c}\text { Quality of } \\
\text { Life }\end{array}$ & $\begin{array}{l}\text { QOL } \\
\text { Rank } \\
\end{array}$ & $\begin{array}{r}1980 \\
\text { rank } \\
\end{array}$ & $\begin{array}{l}1990 \\
\text { rank }\end{array}$ \\
\hline Hawaii & $1,211,537$ & -0.014 & 0.530 & 0.182 & 1 & 0.146 & 4 & 21 & 38 \\
\hline California & $33,871,648$ & 0.126 & 0.458 & 0.085 & 2 & -0.012 & 37 & 39 & 42 \\
\hline Vermont & 608,827 & -0.173 & -0.056 & 0.071 & 3 & 0.159 & 2 & 13 & 13 \\
\hline Colorado & $4,301,261$ & -0.016 & 0.172 & 0.065 & 4 & 0.059 & 17 & 45 & 34 \\
\hline Oregon & $3,421,399$ & -0.045 & 0.106 & 0.058 & 5 & 0.072 & 13 & 24 & 22 \\
\hline Montana & 902,195 & -0.255 & -0.237 & 0.055 & 6 & 0.196 & 1 & 5 & 4 \\
\hline Washington & $5,894,121$ & 0.027 & 0.181 & 0.046 & 7 & 0.019 & 29 & 33 & 41 \\
\hline New Hampshire & $1,235,786$ & 0.033 & 0.164 & 0.037 & 8 & 0.008 & 32 & 20 & 43 \\
\hline Massachusetts & $6,349,097$ & 0.094 & 0.251 & 0.034 & 9 & -0.031 & 42 & 29 & 27 \\
\hline New Mexico & $1,819,046$ & -0.149 & -0.136 & 0.033 & 10 & 0.115 & 7 & 7 & 14 \\
\hline Maine & $1,274,923$ & -0.160 & -0.171 & 0.027 & 11 & 0.117 & 6 & 9 & 9 \\
\hline Utah & $2,233,169$ & -0.054 & -0.023 & 0.021 & 12 & 0.049 & 21 & 36 & 39 \\
\hline Arizona & $5,130,632$ & -0.027 & 0.019 & 0.020 & 13 & 0.032 & 28 & 34 & 20 \\
\hline Florida & $15,982,378$ & -0.060 & -0.036 & 0.020 & 14 & 0.052 & 19 & 19 & 10 \\
\hline Rhode Island & $1,048,319$ & 0.020 & 0.082 & 0.016 & 15 & 0.000 & 33 & 14 & 12 \\
\hline Alaska & 626,932 & 0.055 & 0.130 & 0.014 & 16 & -0.022 & 39 & 41 & 23 \\
\hline Wyoming & 493,782 & -0.193 & -0.264 & 0.014 & 17 & 0.127 & 5 & 2 & 1 \\
\hline New Jersey & $8,414,350$ & 0.190 & 0.336 & 0.012 & 18 & -0.106 & 50 & 46 & 47 \\
\hline Idaho & $1,293,953$ & -0.147 & -0.212 & 0.007 & 19 & 0.094 & 10 & 4 & 5 \\
\hline Connecticut & $3,405,565$ & 0.165 & 0.278 & 0.005 & 20 & -0.096 & 49 & 32 & 32 \\
\hline New York & $18,976,457$ & 0.120 & 0.199 & 0.003 & 22 & -0.070 & 47 & 50 & 50 \\
\hline South Dakota & 754,844 & -0.252 & -0.389 & 0.003 & 21 & 0.154 & 3 & 1 & 2 \\
\hline North Carolina & $8,049,313$ & -0.084 & -0.141 & -0.003 & 23 & 0.049 & 20 & 18 & 17 \\
\hline Nevada & $1,998,257$ & 0.054 & 0.054 & -0.010 & 25 & -0.040 & 43 & 11 & 29 \\
\hline Virginia & $7,078,515$ & -0.034 & -0.085 & -0.010 & 24 & 0.013 & 30 & 30 & 31 \\
\hline Illinois & $12,419,293$ & 0.065 & 0.063 & -0.013 & 26 & -0.049 & 45 & 48 & 48 \\
\hline Nebraska & $1,711,263$ & -0.175 & -0.319 & -0.014 & 27 & 0.095 & 9 & 8 & 16 \\
\hline Wisconsin & $5,363,675$ & -0.036 & -0.099 & -0.014 & 28 & 0.011 & 31 & 40 & 37 \\
\hline District of Columbia & 572,059 & 0.126 & 0.154 & -0.015 & & -0.088 & & & \\
\hline Maryland & $5,296,486$ & 0.110 & 0.126 & -0.016 & 29 & -0.079 & 48 & 47 & 45 \\
\hline South Carolina & $4,012,012$ & -0.100 & -0.214 & -0.018 & 30 & 0.047 & 22 & 25 & 18 \\
\hline Arkansas & $2,673,400$ & -0.185 & -0.364 & -0.023 & 31 & 0.094 & 11 & 6 & 3 \\
\hline Iowa & $2,926,324$ & -0.140 & -0.293 & -0.023 & 32 & 0.067 & 14 & 10 & 15 \\
\hline Delaware & 783,600 & 0.043 & -0.010 & -0.026 & 33 & -0.046 & 44 & 35 & 30 \\
\hline Missouri & $5,595,211$ & -0.107 & -0.247 & -0.026 & 34 & 0.045 & 23 & 43 & 40 \\
\hline Oklahoma & $3,450,654$ & -0.179 & -0.369 & -0.028 & 35 & 0.087 & 12 & 22 & 21 \\
\hline Tennessee & $5,689,283$ & -0.102 & -0.249 & -0.029 & 36 & 0.040 & 24 & 31 & 28 \\
\hline Louisiana & $4,468,976$ & -0.105 & -0.264 & -0.032 & 37 & 0.040 & 26 & 17 & 8 \\
\hline Kansas & $2,688,418$ & -0.133 & -0.312 & -0.034 & 38 & 0.055 & 18 & 12 & 19 \\
\hline Ohio & $11,353,140$ & -0.024 & -0.143 & -0.035 & 39 & -0.011 & 36 & 38 & 33 \\
\hline Georgia & $8,186,453$ & -0.022 & -0.145 & -0.036 & 40 & -0.015 & 38 & 28 & 36 \\
\hline Indiana & $6,080,485$ & -0.032 & -0.168 & -0.039 & 41 & -0.010 & 35 & 44 & 44 \\
\hline Pennsylvania & $12,281,054$ & -0.011 & -0.135 & -0.039 & 42 & -0.023 & 40 & 37 & 35 \\
\hline Minnesota & $4,919,479$ & -0.008 & -0.134 & -0.040 & 43 & -0.025 & 41 & 42 & 46 \\
\hline North Dakota & 642,200 & -0.235 & -0.495 & -0.040 & 44 & 0.112 & 8 & 15 & 6 \\
\hline Kentucky & $4,041,769$ & -0.121 & -0.326 & -0.044 & 45 & 0.040 & 25 & 23 & 24 \\
\hline Alabama & $4,447,100$ & -0.114 & -0.318 & -0.045 & 47 & 0.034 & 27 & 26 & 26 \\
\hline West Virginia & $1,808,344$ & -0.162 & -0.392 & -0.045 & 46 & 0.064 & 15 & 16 & 11 \\
\hline Texas & $20,851,820$ & -0.041 & -0.203 & -0.046 & 48 & -0.010 & 34 & 27 & 25 \\
\hline Michigan & $9,938,444$ & 0.051 & -0.061 & -0.047 & 49 & -0.066 & 46 & 49 & 49 \\
\hline Mississippi & $2,844,658$ & -0.168 & -0.427 & -0.053 & 50 & 0.061 & 16 & 3 & 7 \\
\hline
\end{tabular}




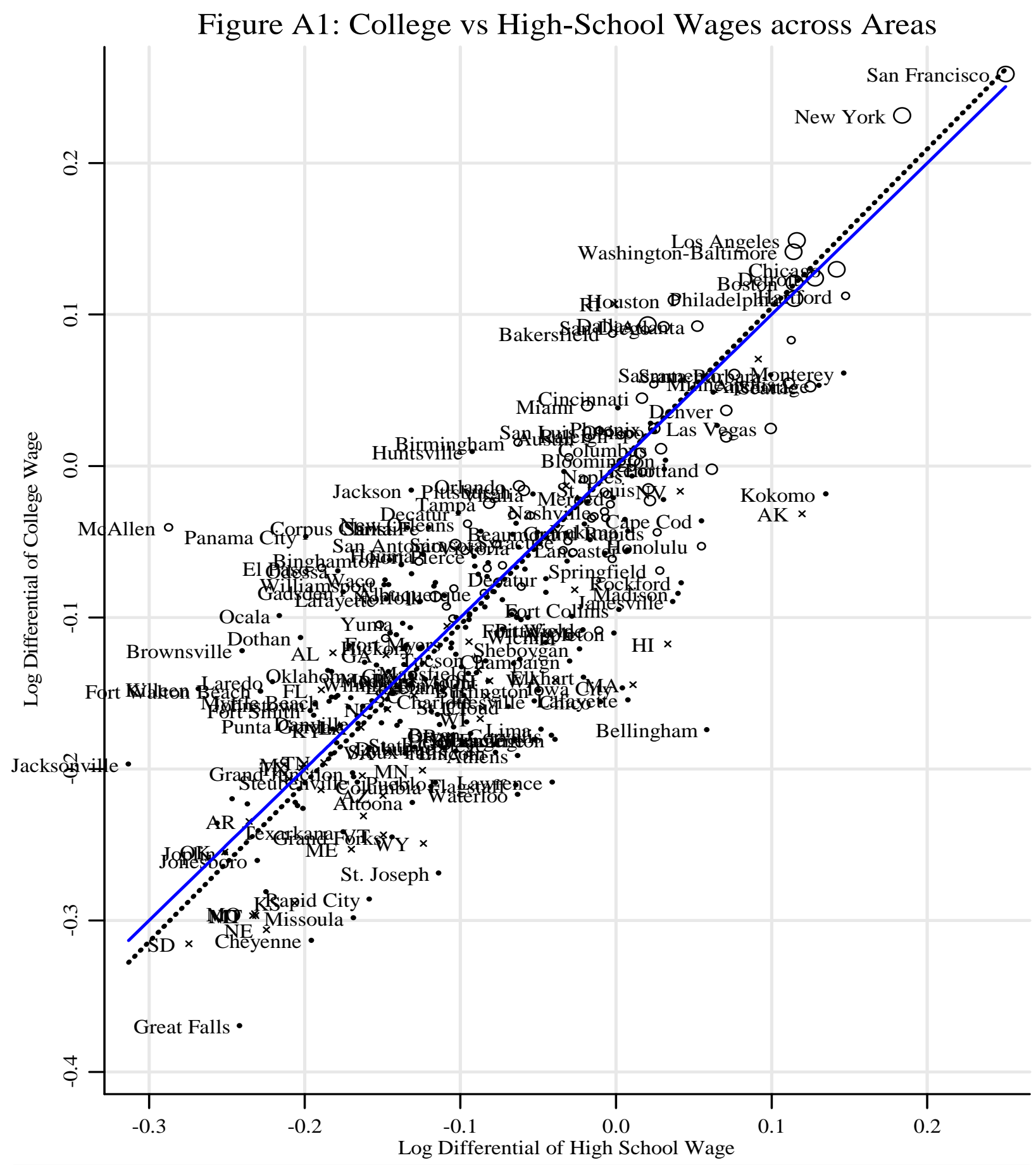

$\begin{array}{llllll} & \text { METRO POP } & \bigcirc & >5.0 \text { Million } & \ldots \ldots \ldots \ldots \ldots \ldots & \text { Weighted Fit: slope }=1.047 \text { (s.e. } 0.043) \\ \circ & 1.5-5.0 \text { Million } & \circ & 0.5-1.5 \text { Million } & & \\ & <0.5 \text { Million } & \times & \text { Non-Metro Areas } & & \end{array}$


Figure A2: Housing-Cost versus Rent Differentials across Areas

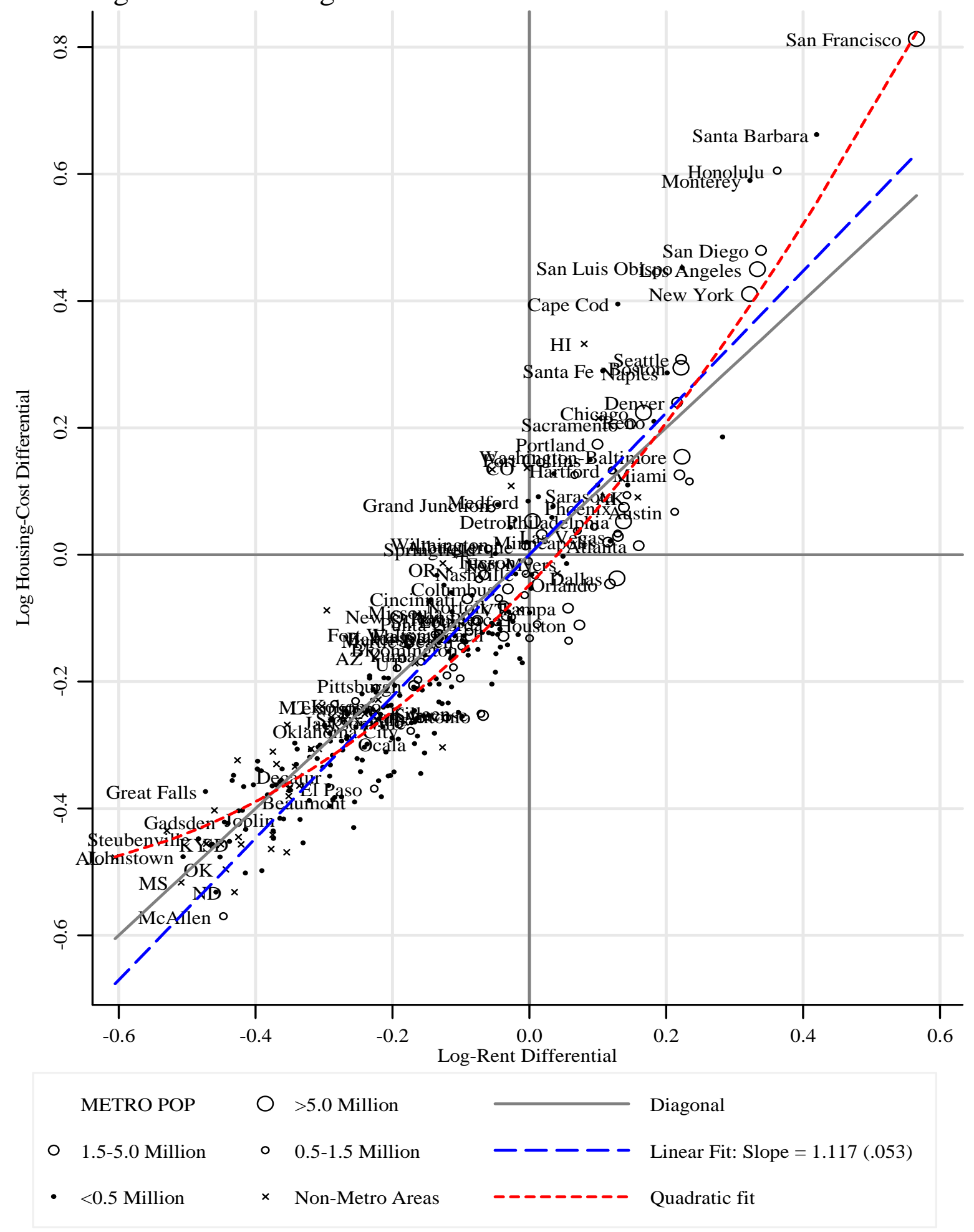


Figure A3: Linear vs Quadratic Approximation of Quality of Life

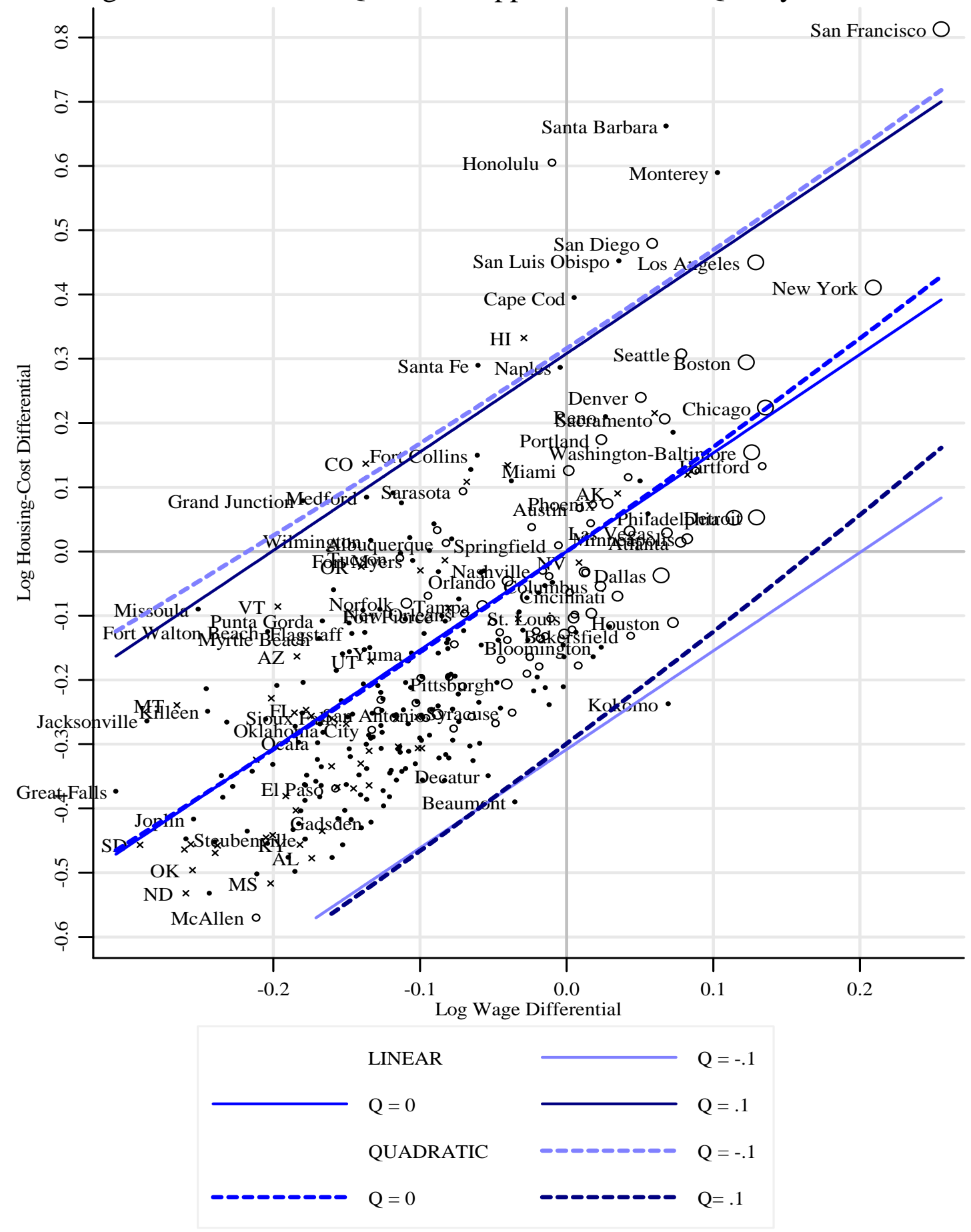


Figure A4: Compositional Wage and Housing Costs across Areas: 2000

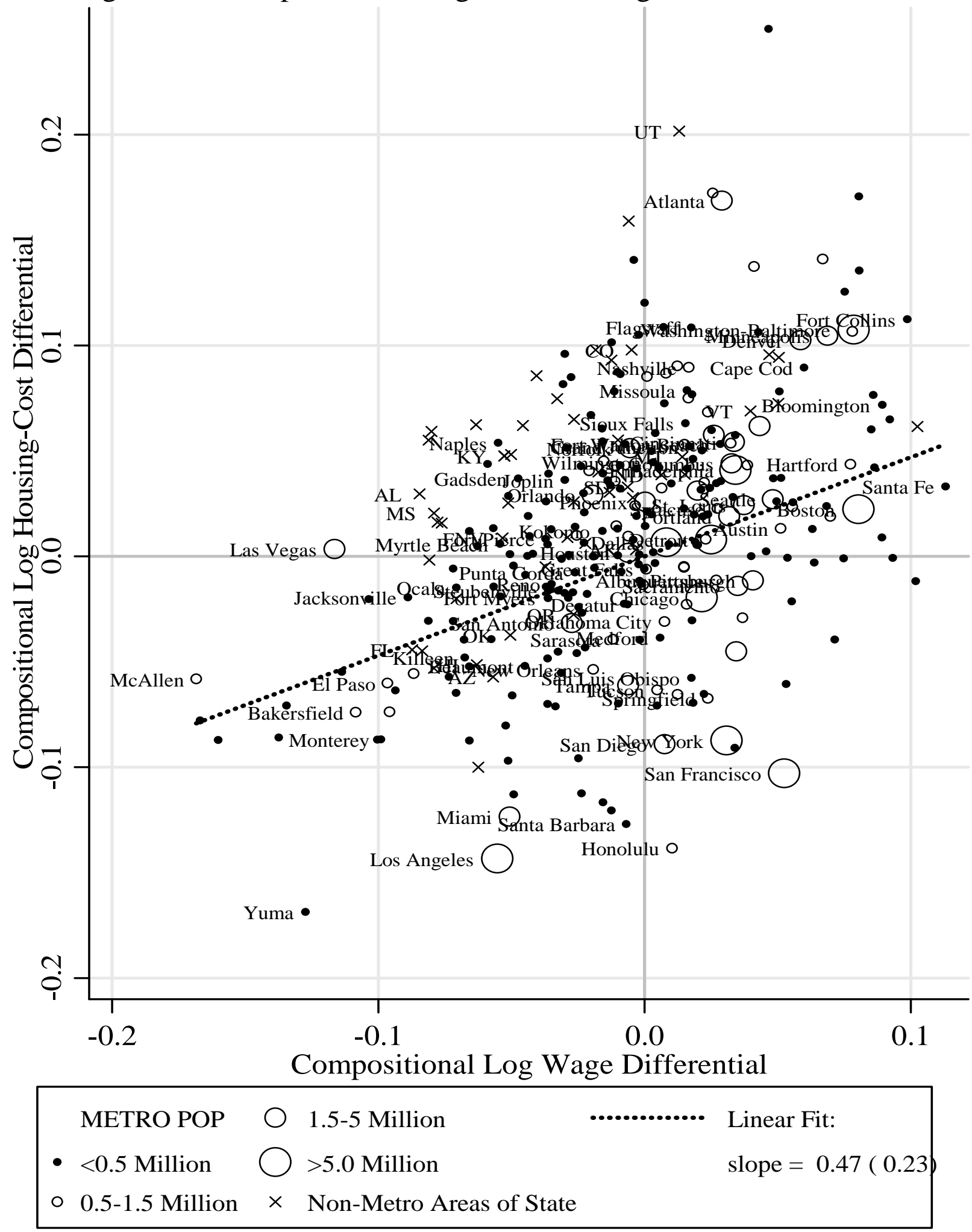

